\title{
The Record of Environmental and Microbial Signatures in Ancient Microbialites: The Terminal Carbonate Complex from the Neogene Basins of Southeastern Spain
}

\author{
Raphaël Bourillot 1,* Emmanuelle Vennin 2®D, Christophe Dupraz ${ }^{3}$, Aurélie Pace ${ }^{1}$, \\ Anneleen Foubert ${ }^{4}$, Jean-Marie Rouchy ${ }^{5}$, Patricia Patrier ${ }^{6}{ }^{\mathbb{D}}$, Philippe Blanc ${ }^{7}$, \\ Dominique Bernard ${ }^{8}$ (D), Julien Lesseur ${ }^{8,9}$ and Pieter T. Visscher ${ }^{2,10}$ (D) \\ 1 EA 4592, Géoressources \& Environnement, Bordeaux INP, Université Bordeaux Montaigne, Talence, \\ 33607 Pessac, France; aurelie.pace@univ-angers.fr \\ 2 Laboratoire Biogéosciences, UMR 6282, UBFC/CNRS, Université Bourgogne Franche-Comté, 21000 Dijon, \\ France; emmanuelle.vennin@u-bourgogne.fr (E.V.); pieter.visscher@uconn.edu (P.T.V.) \\ 3 Department of Geological Sciences, Stockholm University, 11419 Stockholm, Sweden; \\ christophe.dupraz@geo.su.se \\ 4 Department of Geosciences, Fribourg University, Chemin du Musée 6, 1700 Fribourg, Switzerland; \\ anneleen.foubert@unifr.ch \\ 5 Muséum national d'histoire naturelle, 75005 Paris, France; jmrouchy@free.fr \\ UMR 7285, IC2MP, CNRS, Université de Poitiers, 86000 Poitiers, France; patricia.patrier@univ-poitiers.fr \\ 7 Lithologie Bourgogne, 21600 Longvic, France; litho.b@orange.fr \\ 8 CNRS, Université de Bordeaux, Bordeaux INP, ICMCB, UMR 5026, 33600 Pessac, France; \\ dominique.bernard@icmcb.cnrs.fr (D.B.); julien.lesseur@irt-saintexupery.com (J.L.) \\ 9 IRT Saint Exupery, B612, 31400 Toulouse, France \\ 10 Department of Marine Sciences, University of Connecticut, Groton, CT 06340, USA \\ * Correspondence: raphael.bourillot@bordeaux-inp.fr
}

Received: 11 February 2020; Accepted: 8 March 2020; Published: 19 March 2020

\begin{abstract}
The Messinian microbialites of the Terminal Carbonate Complex (TCC) from the Neogene basins of southeastern Spain show both diversified morphologies and an excellent preservation of primary microbial microstructures. Their stratigraphic architecture, fabric (micro-, meso-, and macro-fabric), and mineralogical composition were investigated in eight localities from three sedimentary basins of southeastern Spain: The Sorbas and Bajo Segura basins and the Agua Amarga depression. Two recurrent microbialite associations were distinguished. Laterally linked low relief stromatolites predominated in Microbialite Association 1 (MA1), which probably formed in low energy lagoons or lakes with fluctuating normal marine to hypersaline water. The microfabrics of MA1 reflected the predominance of microbially induced/influenced precipitation of carbonates and locally (Ca)-Mg-Al silicates. Microbialite Association 2 (MA2) developed in high energy wave and tidal influenced foreshore to shoreface, in normal marine to hypersaline water. High-relief buildups surrounded by mobile sediment (e.g., ooids or pellets) dominated in this environment. MA2 microbialites showed a significant proportion of thrombolitic mesofabric. Grain-rich microfabrics indicated that trapping and binding played a significant role in their accretion, together with microbially induced/influenced carbonate precipitation. The stratigraphic distribution of MA1 and MA2 was strongly influenced by water level changes, the morphology and nature of the substratum, and exposure to waves. MA1 favorably developed in protected areas during third to fourth order early transgression and regression phases. MA2 mostly formed during the late transgressions and early regressions in high energy coastal areas, often corresponding to fossil coral reefs. Platform scale syn-sedimentary gypsum deformation and dissolution enhanced microbial carbonate production, microbialites being thicker and more extended in zones of maximum deformation/dissolution.
\end{abstract}


Microbial microstructures (e.g., microbial peloids) and microfossils were preserved in the microbialites. Dolomite microspheres and filaments showed many morphological similarities with some of the cyanobacteria observed in modern open marine and hypersaline microbialites. Dolomite potentially replaced a metastable carbonate phase during early diagenesis, possibly in close relationship with extracellular polymeric substances (EPS) degradation. Double-layered microspheres locally showed an inner coating made of ( $\mathrm{Ca}$ )-Mg-Al silicates and carbonates. This mineral coating could have formed around coccoid cyanobacteria and indicated an elevated $\mathrm{pH}$ in the upper part of the microbial mats and a potential dissolution of diatoms as a source of silica. Massive primary dolomite production in TCC microbialites may have resulted from enhanced sulfate reduction possibly linked to the dissolving gypsum that would have provided large amounts of sulfate-rich brines to microbial mats. Our results open new perspectives for the interpretation of ancient microbialites associated with major evaporite deposits, from microbe to carbonate platform scales.

Keywords: microbialites; Terminal Carbonate Complex; Messinian Salinity Crisis; paleoenvironments; southeastern Spain; biosignatures; dolomite

\section{Introduction}

Microbialites, i.e., lithified benthic microbial mats, emerged between ca. 3.7 and $3.4 \mathrm{Ga}$ and are remnants of the oldest known complex ecosystems on Earth [1-3]. The biogeochemical reactions mediated by microbial communities within mats have played a primary role in the evolution of Earth's surface since then [4-7]. Lithifying microbial mats have been a major biological carbonate factory during most of Earth's history [8] and could have participated in large scale carbon capture and storage through their fossilization into microbialites [9]. The unique (both in terms of duration and environmental spectrum) sedimentary record of microbialites offers an exceptional opportunity to explore the evolution of biological and environmental conditions through time.

The study of modern microbialites in open marine [10-12], freshwater [13-15], or marine and continental hypersaline environments [13-17], has provided an increasingly detailed and complex picture of the environmental (extrinsic) vs. microbial (intrinsic) controls on the structure and mineralization processes in these complex ecosystems. A fundamental challenge for geomicrobiologists is to determine whether the processes documented in modern mats were active in ancient microbial mats as well. However, the interpretation of ancient microbialites cannot be solely based on comparisons with extant microbial sedimentary systems due to: (i) long-term environmental changes that produced physico-chemical conditions (e.g., seawater $\mathrm{pH}$, salinity, temperature, alkalinity, atmospheric $\mathrm{pCO}_{2}$ ) contrasting with modern settings and (ii) post-depositional (diagenetic) alterations that affected the initial fabrics and mineral products (e.g., organic matter decomposition and mineralization, mineral dissolution and replacement, outcrop quality) [18-20]. Actually, less than one percent of ancient stromatolites (the dominant type of microbialites in the Precambrian) display fossilized microbiota [18]. Comprehensive studies of well-preserved microbialites from various geological periods [21,22] will enhance understanding of which environmental and biological information is preserved in the microbialite sedimentary record.

The Terminal Carbonate Complex (TCC) is a shallow water carbonate platform system that developed in most of the peripheral sedimentary basins of the western Mediterranean margins during the Messinian Salinity Crisis (Internal Zone of the Betics, Balearic Promontory, Rifian corridors) [23-28]. This sedimentary unit shows abundant and morphologically diverse microbialites $[29,30]$ and as such represents an excellent fossil case study. Because of their preservation and of the excellent quality of outcrops in SE Spain, TCC microbialites have been used as an analogue for the prediction of subsurface ooid-microbialite carbonate reservoirs [29,31]. Although TCC microbialites have been compared with both older (e.g., Paleozoic) [32] and modern potential counterparts [33], the paleoenvironmental 
conditions in which they thrived are still discussed, being either interpreted as open marine [25,33] or as fluctuating open marine to hypersaline [24,30,32]. They appear to be partly composed of dolomite [30,32], a mineral that is uncommon in modern microbial mats [20,34-36], but widespread in ancient microbialites [37]. The origin of this dolomite, either microbial, diagenetic, or both, and its relationship with Messinian evaporite brine seepage still needs to be assessed [27,32].

In this paper, we investigated TCC microbialites at multiple scales: (i) At the platform (kilometer) scale, we examined the architecture and the spatial and temporal evolution of microbial deposits within a high resolution sequence stratigraphic framework. (ii) A study of microbialite fabrics and of the composition of contemporaneous sediments and organisms (borers and encrusters) at the facies (meter) scale allowed a better understanding of microbial accretion processes and of paleoenvironmental settings. (iii) Petrographic and mineralogical analyses were performed to characterize microbially mediated mineral products and microfossils. (iv) Finally, the comparison of microbialites from the TCC with several modern microbialite systems (Great Salt Lake, Cuba, Bahamas) was used to infer the paleoenvironmental conditions, the composition of fossil microbial communities, and the impact of microbial metabolisms, exopolymeric substances, and diagenesis on the formation of microbialites.

\section{Geological Setting}

The Terminal Carbonate Complex (TCC) microbialites were investigated in eight localities from the Cabo de Gata volcanic massif (Las Negras), the Sorbas Basin (Sorbas, Cariatiz, Góchar, Moras, Hueli), and the Bajo Segura Basin (Benejuzar, Santa Pola) (Figure 1).

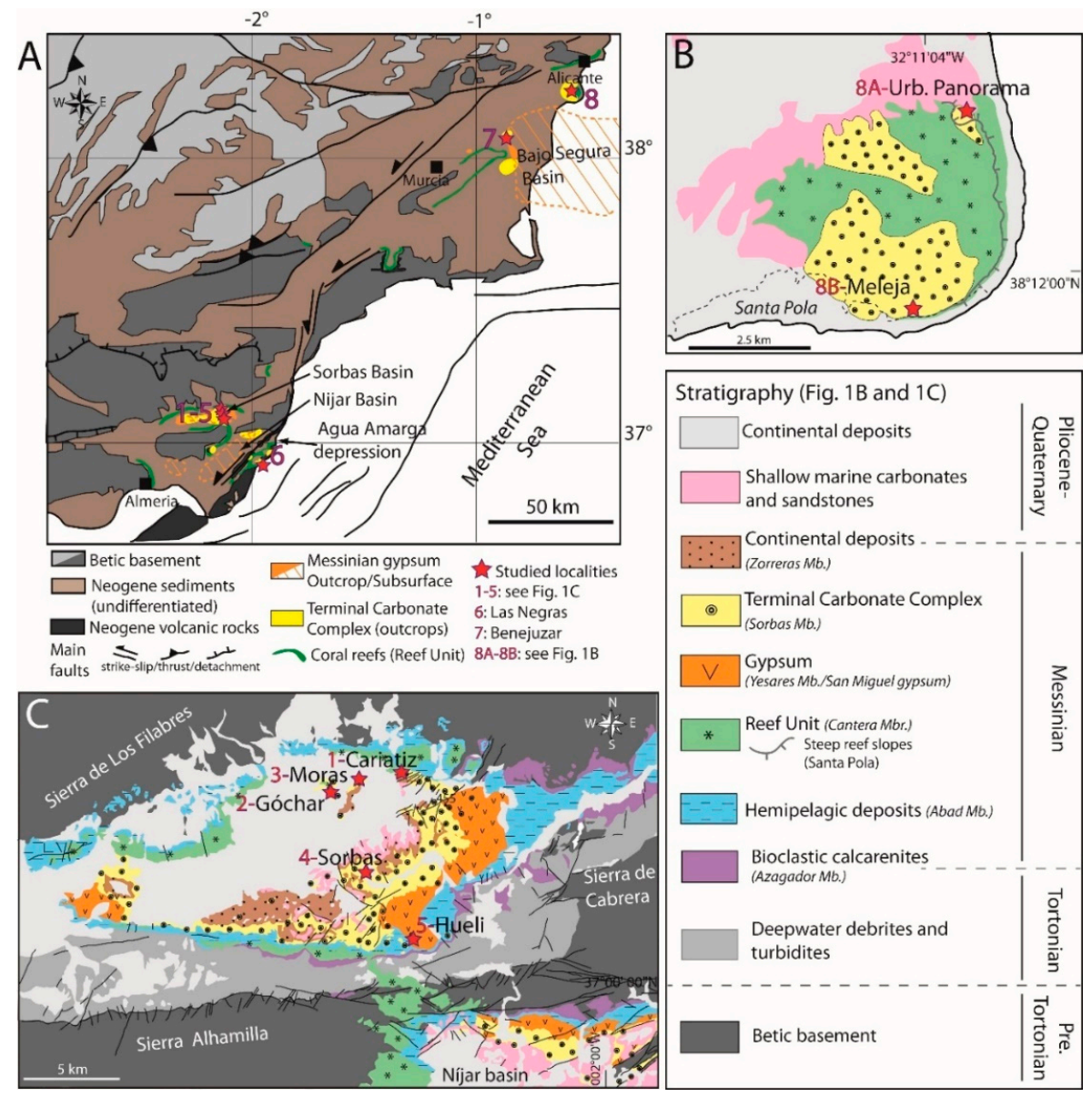

Figure 1. (A) Simplified geological map of southeastern Spain with the position of the studied localities (1-8; Table S1). (B) Geological map of the Santa Pola area. (C) Geological map of the Sorbas Basin. Urb. = urbanización. 
A relatively thick Messinian series (up to $400 \mathrm{~m}$ locally in the Sorbas Basin) is preserved in the studied areas. In the Sorbas Basin, the TCC overlies the gypsum unit (Yesares Member; ca. $120 \mathrm{~m}$ thick) deposited during the paroxysmal restriction of the Messinian Salinity Crisis (MSC), beginning at $5.96 \mathrm{Ma}$ (Figures 1C and 2) [38,39]. Following gypsum deposition, a water level rise led to the reflooding of the margins and subsequent deposition of the TCC carbonate platforms (up to 90 m thick; Figure 2).
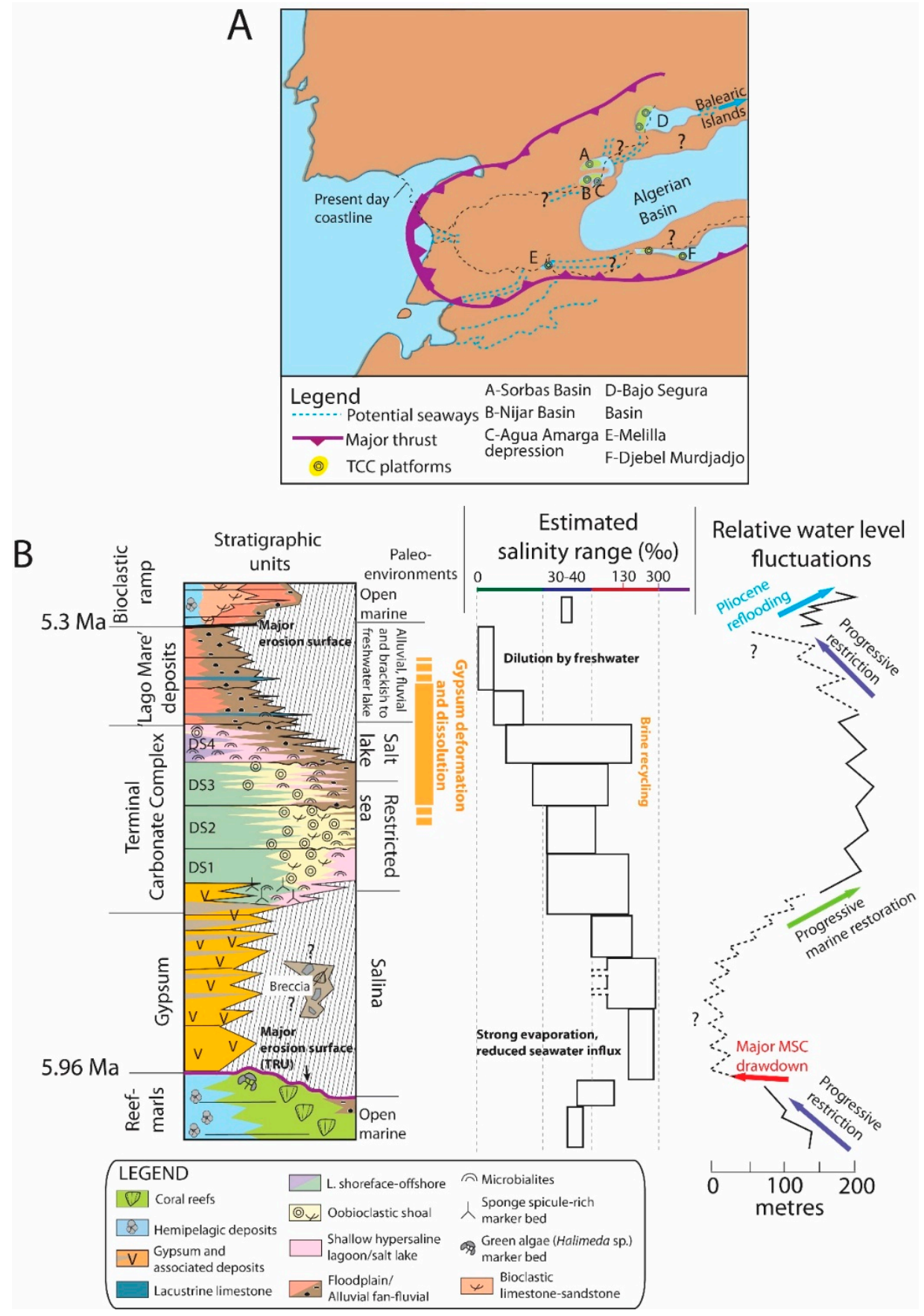

Figure 2. (A) Paleogeography of the western Mediterranean at the times of the Terminal Carbonate Complex (TCC) deposition; (B) Chronostratigraphy and paleoenvironmental events recorded by Messinian deposits in the peripheral basins of southeastern Spain. The vertical scale is not proportional to absolute durations. For example, the Terminal Carbonate Complex has been voluntarily exaggerated relative to the Gypsum Unit. 
The TCC was interpreted in several regions of the western Mediterranean periphery (southeastern Spain, Balearic Islands, Morocco, Algeria; Figure 2A) as a shallow water carbonate unit rich in ooids and microbialites [23,24,27-29]. In the studied areas, the TCC deposited on two different substrates (Figures 1 and 3): it conformably overlies the gypsum in the center of the basins (e.g., Sorbas and Nijar basins), while it is onlapping the main MSC erosional surface (Top Reef Unconformity (TRU)) on the margins [27]. The TRU covers a pre-MSC reef unit ( $\sim 6.5$ to $\sim 6 \mathrm{Ma})$, characterized by a variable morphology, from fringing reefs in the Sorbas Basin and on the Cabo de Gata massif to a circular island reef with a leeward/windward zonation in Santa Pola (Figures 1 and 3) [40,41]. The reefal substrate configuration strongly controlled the geometry and facies distribution of the TCC platforms [27]. Alluvial, fluvial, and brackish water lake Lago Mare-type facies (named Zorreras Member, Mb., in the Sorbas Basin) deposited at the end of the Messinian (Figure 2B). Finally, marine carbonates and marls record the early Pliocene reflooding in the Agua Amarga depression and in the Sorbas Basin (Figures 1C and 2) [42].

The TCC constitutes a third order depositional sequence, which can be subdivided into four fourth order transgressive-regressive depositional sequences (DS1 to DS4) bounded at their top by sequence boundaries, generally corresponding to water level minima (SB1 to SB4; Figures 2B and 3) [26,30]. During TCC deposition, the three studied zones formed small interconnected shallow marine depressions (Figure 2A [29]). The Sorbas Basin was surrounded to the north and to the south by the Betic metamorphic basement, the erosion of which supplied detrital material to the TCC platforms. Siliciclastic inputs were significant on the northern margin of the basin, where an intensification of the detrital flux was recorded by the southward progradation of a kilometer scale alluvial fan from DS3 and through the deposition of the Zorreras Mb. [30,42]. In the Agua Amarga depression, minor quantities of calco-alkaline volcanic material were delivered to the platform through the erosion of the Cabo de Gata Middle to Upper Miocene volcanic relief. The isolated platform of Santa Pola (Figure 1B) shows no evidence of a significant detrital influx.

\section{Terminology}

The term microbialite is used here for organosedimentary microbial benthic deposits formed through grain trapping and binding and/or direct microbially influenced or induced precipitation $[19,43]$. In the current investigation, TCC microbialites were investigated on four spatial scales (Figure 4 and Table 1): (1) The macrofabric corresponded both to the macroscopic geometry (hemispheroid, column, etc.) and to the mode of occurrence (stacked or linked) of the microbial buildups. For complex microbialites showing an imbrication of two types of macrofabrics (e.g., centimeter scale hemispheroids included within a meter scale hemispheroid), we used the terms first order macrofabric for the larger scale and second order macrofabric for the smaller one. (2) The mesofabric was the internal organization of the microbialite defined macroscopically. Two mesofabrics were recognized: stromatolites showed a laminated structure [44], while thrombolites [45] showed a clotted structure (Figure 4). (3) The microfabric was the internal structure of the microbialite, defined on thin sections. The classification of microfabrics established in this work (Figure 4) was based both on the texture and on the composition; i.e., precipitated in situ vs. trapped and bound components. Eight component categories were defined:

- Cements (i) and peloids (ii), as well as various microstructures and microfossils (Table 2) were considered exclusively as in situ components;

- Micrite (iii) and organic matter particles (iv) were either formed in situ and/or were trapped;

- Siliciclastic grains (v), ooids (vi), fecal pellets (vii), and bioclasts (viii), except borers and encrusters, were considered exclusively as trapped grains.

(4) Finally, we defined microstructures and microfossils as the smallest organized constituents distinguishable with the scanning electron microscope (e.g., fossilized bacteria; Figure 4 and Table 2). 


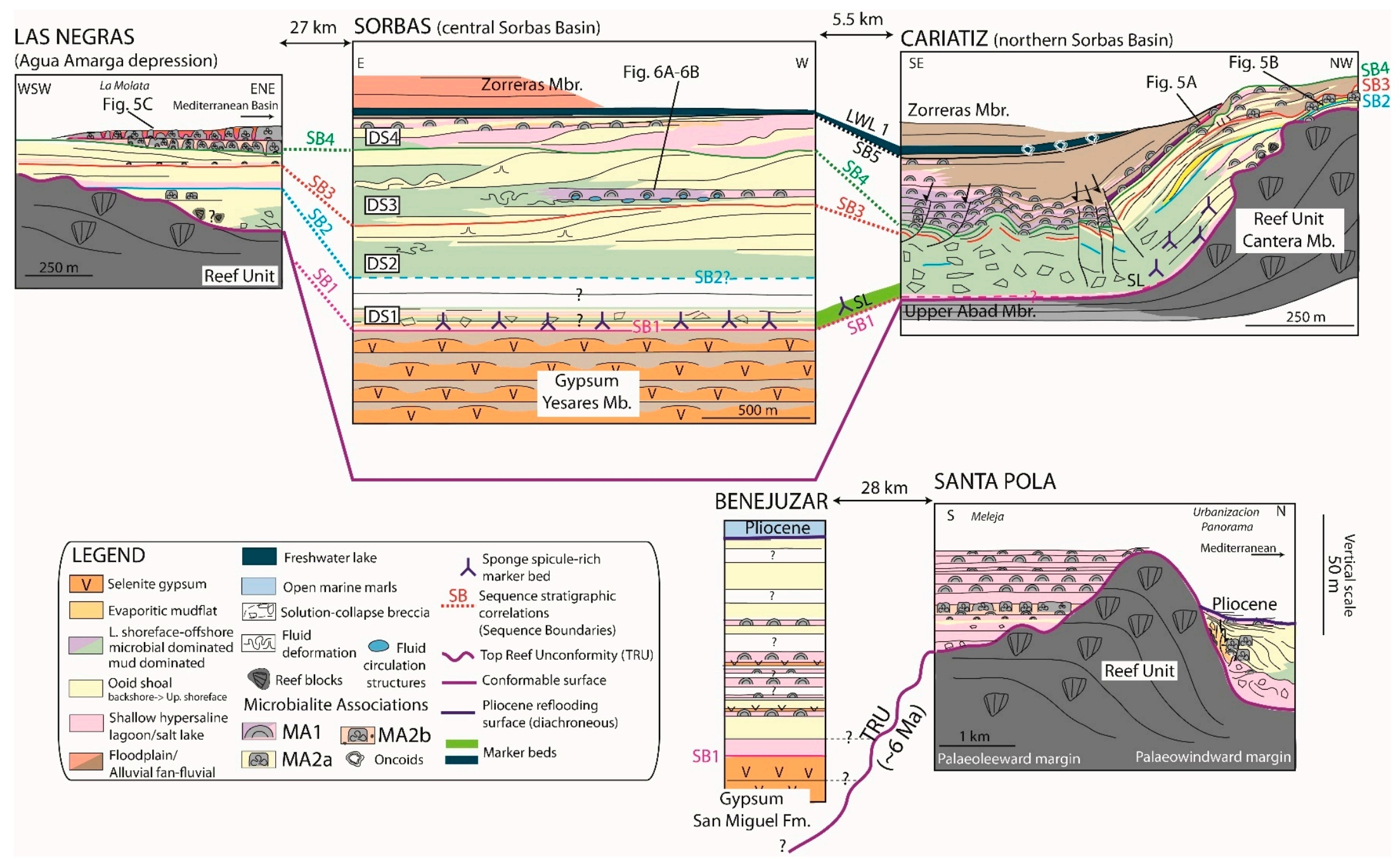

Figure 3. Depositional environments, stratigraphic architecture and correlations of the Terminal Carbonate Complex in the studied localities. The distribution of microbialite associations MA1, MA2a, and MA2b is represented on this scheme. The stratigraphy from Benejuzar is a synthesis of $[46,47]$. Mb. $=$ Member; Fm. = Formation. 

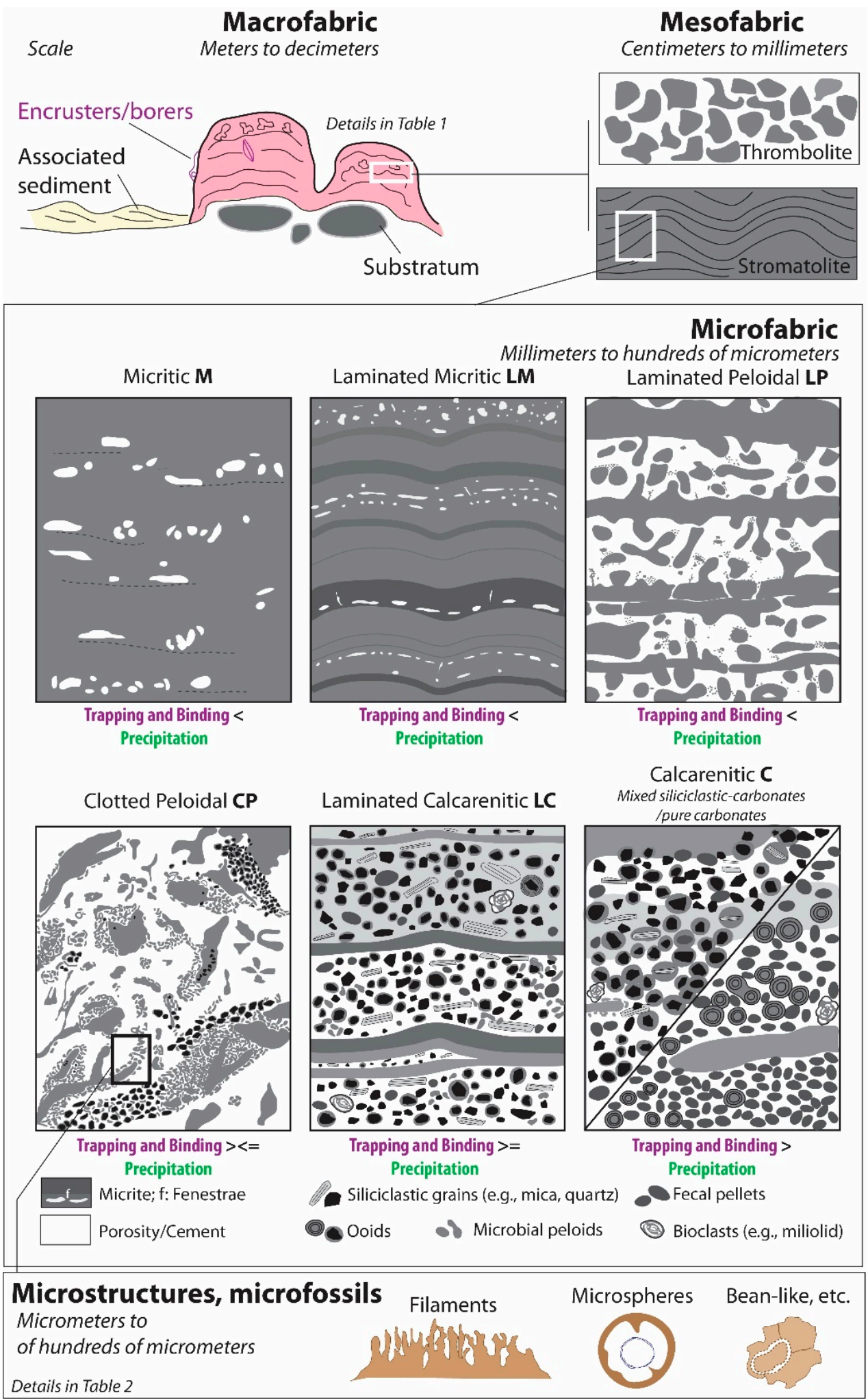

Figure 4. The various scales of microbialite fabrics used in this study.

\section{Methods}

The vertical and lateral evolution of microbialite fabrics and associated facies was studied through the physical correlation of 25 vertical cross-sections defining inner to outer platform transects along hundreds of meters (e.g., Góchar) to two kilometer long outcrops (e.g., Sorbas). Most of the 
microbialite-bearing beds were sampled. The lateral variation of macrofabrics was assessed by physically correlating hundreds of meters to $\mathrm{km}$ long microbialite-bearing beds, all the observations being noted on outcrop photomosaics. Microbialite dimensions (Table 1) were measured in the field perpendicularly to the bedding, more rarely on bed surfaces. Eighty-eight (88) thin sections and 30 slabs were made from microbialite samples and polished at $0.25 \mu \mathrm{m}$ for petrographic observations. Half of each thin section was stained with Dickson's solution [48] to differentiate calcite and dolomite. Thin sections were further analyzed under a Zeiss Axiophot polarizing microscope (Leica polarizing microscope (Zeiss Group, Wanger, Germany). A few selected thin sections were subsequently observed by cathodoluminescence (Technosyn $8200 \mathrm{MKII}$; set to $20 \mathrm{kV}$ and $600 \mathrm{~mA}$ ) to determine microfabrics and differentiate between primary and diagenetic mineral phases. The same samples were observed in reflected light fluorescence under a Olympus BH2-RFC microscope (Olympus, Tokyo, Japan) (exciter filter 460-490 nm; dichroic mirror $505 \mathrm{~nm}$; barrier filter $515 \mathrm{~nm}$ ) to evaluate the presence of fluorescent organic matter and, if present, assess its location in the carbonate material. The chronology of boring and/or encrusting organisms and diagenetic phases was defined on slabs and thin sections based on superposition and cross-cutting relationships.

The bulk mineralogy of 22 microbialite samples (Figure 3B) was assessed using a Bruker D4 powder XRD diffractometer (Bruker, Billerica, MA, USA). Instrument parameters were set to $40 \mathrm{kV}$ accelerating voltage and $30 \mathrm{~mA}$ current. Scans were run from $2^{\circ}$ to $64^{\circ} 2$ theta with a step of $0.02^{\circ} 2$ theta and a counting time of $2 \mathrm{~s}$. Mineral phases were determined with the EVA software (Bruker, Billerica, MA, USA). Dolomite and calcite percentages and the $\mathrm{mol} \%$ of $\mathrm{Mg}^{2+}$ in dolomite were calculated (Table S2; Figure 3B) from XRD spectra following the methods of [49,50]. The relative surface area (\%) of the siliciclastic fraction and carbonates in their various forms (e.g., micrite, peloids, cements) was determined through random point counting on high resolution thin section scans (image resolution 4800 dpi; 200 points per thin section) with the software JMicrovision (v. 1.3.3) [51]. The grain size of the siliciclastic fraction was calculated by measuring the maximal length of 200 grains per thin section using the same software.

Microstructures were observed in secondary and backscattered electrons on 19 carbon-coated polished slabs $\left(0.25 \mu \mathrm{m} \mathrm{Al}{ }_{2} \mathrm{O}_{3}\right.$ polish) with a JEOL 6400 SEM (JEOL Ltd., Tokyo, Japan) equipped with an energy-dispersive X-ray spectrometer (EDS) for elemental analyses. For optimal observation, samples were immerged in acetic acid (10\%) for $30 \mathrm{~s}$ to enhance dolomite relief.

A three-dimensional visualization of the microfabrics was performed on two samples using the PHOENIX Nanotom X-ray $\mu$-CT system installed at the Department of Materials Engineering at the University of Leuven (KU Leuven, Belgium). Samples were rotated over $360^{\circ}$ at rotation steps of $0.1^{\circ}$. Samples were scanned at 1.0 and $1.4 \mu \mathrm{m}$ pixel resolution, respectively. Data were derived with a tube voltage of $90 \mathrm{kV}$ and a main current of $50 \mu \mathrm{A}$. The detector was a Hamamatsu flat detector (Hamamatsu Photonics, Hamamatsu, Japan) $(120 \times 120 \mathrm{~mm}-2300 \times 2300$ pixels $)$. Frame averaging was set at 3 to enhance the signal to noise ratio. To reduce beam hardening effects, a $0.1 \mathrm{~mm} \mathrm{Cu}$ filter was inserted during measurements. Reconstruction of the volumetric data was performed using a cone beam Feldkamp algorithm. Image analysis and visualization were done using VGStudio Max (v. 3.2., Volume Graphics GmbH, Heidelberg, Germany) (Volume Graphics) and CTvox (v. 3.0, Bruker-Skyscan, Billerica, MA, USA).

X-ray nanotomography was performed on one microbialite sample by Xradia in their Applications Department in Pleasanton (CA, USA) using a Xradia UltraXRM-L200 (Xradia is presently part of the Zeiss Group, Germany). The small sample of about $60 \mu \mathrm{m}$ in diameter was scanned at an energy of $8 \mathrm{keV}$. One-thousand-six-hundred projections of $1000 \times 1000$ pixels of $65 \mathrm{~nm}$ were acquired on $180^{\circ}$ with an exposure time of $75 \mathrm{~s}$. The 3D image was reconstructed from the projections using the Xradia UltraXRM-L200 embedded software. Segmentation and 3D rendering were realized with AVIZOC (Thermo Fisher, Waltham, MA, USA). 
Table 1. Characteristics and environmental interpretation of the microbialite macrofabrics of the Terminal Carbonate Complex.

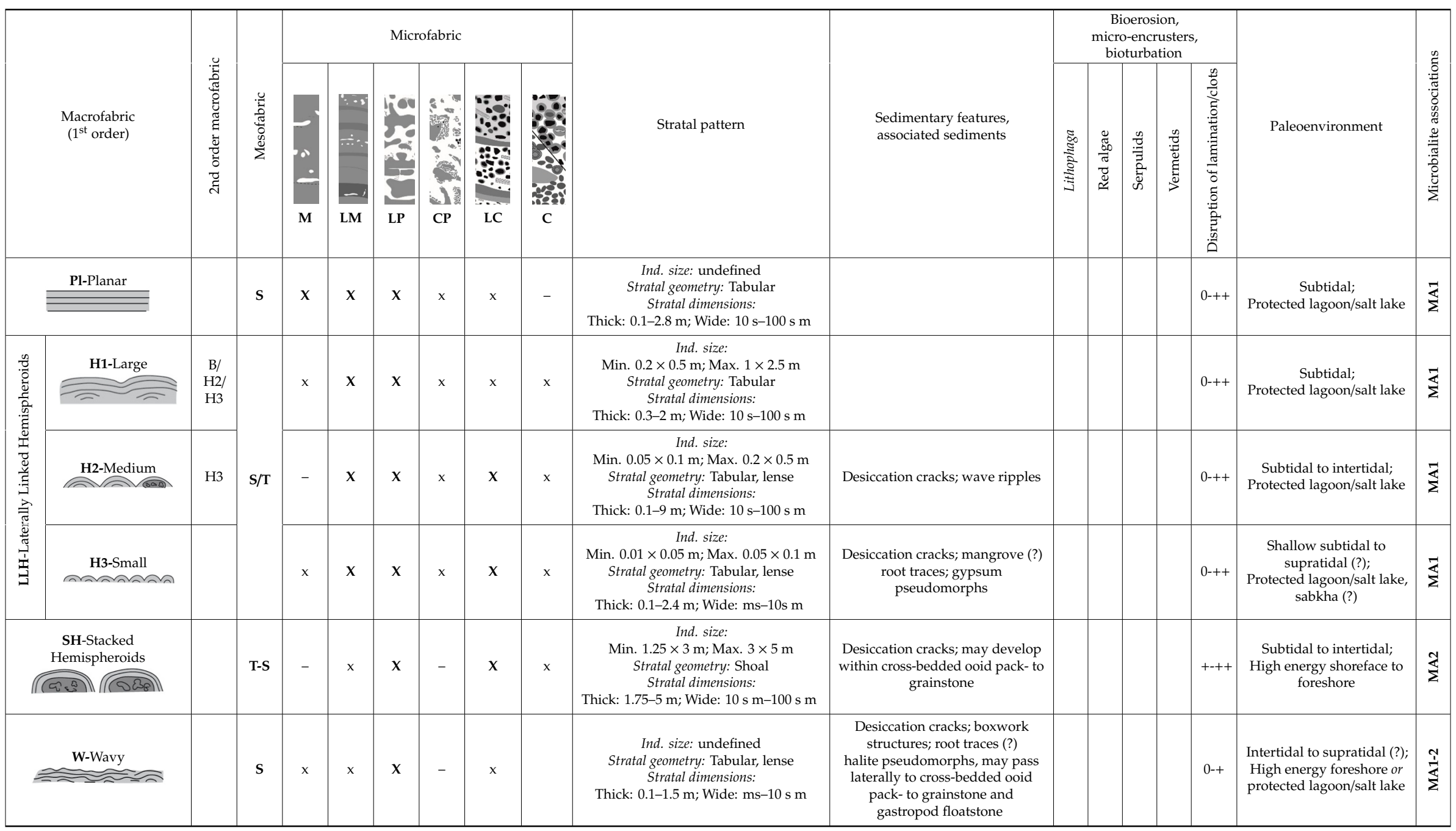


Table 1. Cont.

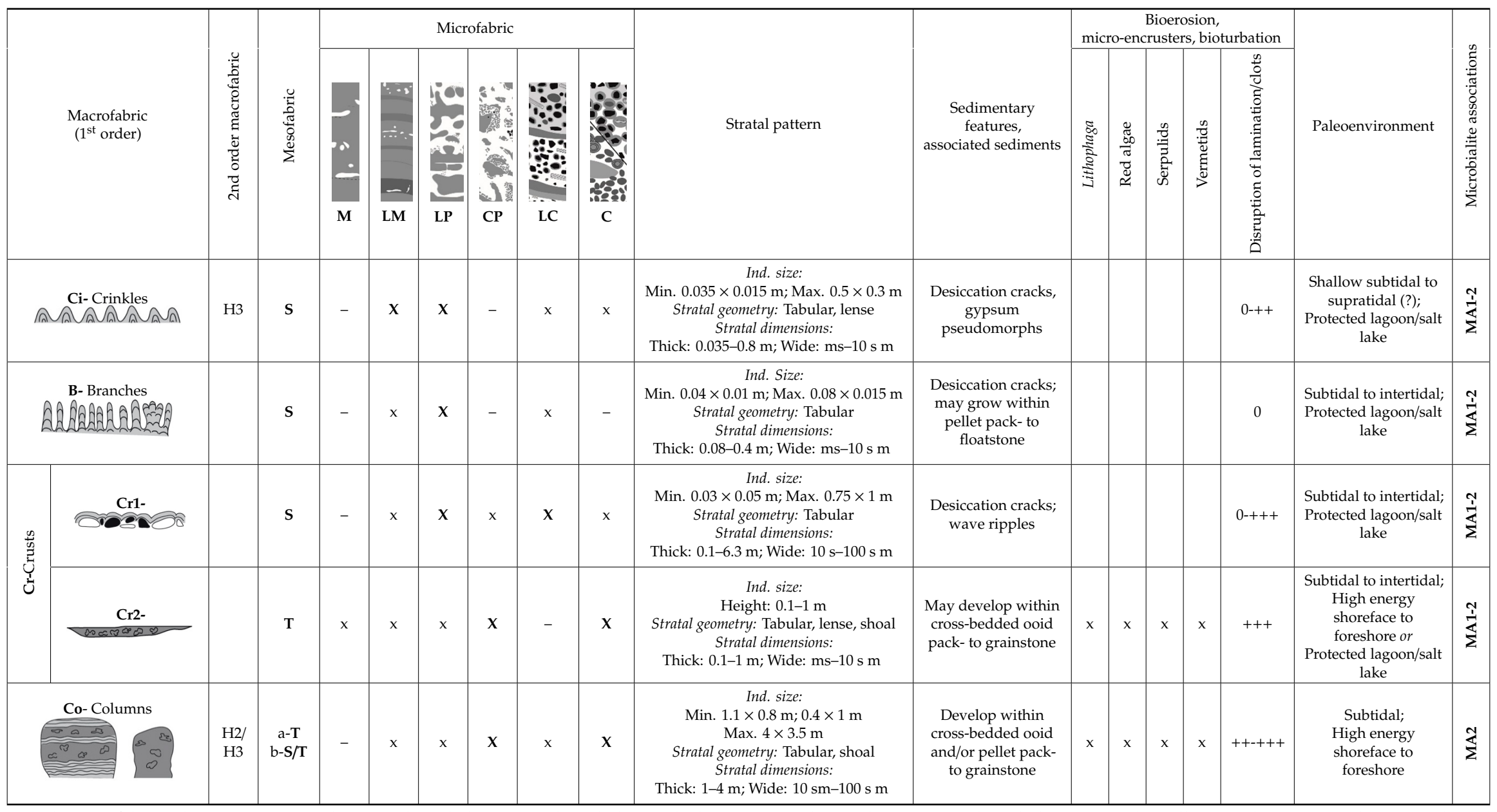

In the mesofabric column, $\mathrm{S}=$ stromatolitic; $\mathrm{T}=$ thrombolitic; $\mathrm{T}-\mathrm{S}=$ thrombolitic at the base, stromatolitic at the top; $\mathrm{T} / \mathrm{S}=$ thrombolitic passing laterally to or alternating with stromatolitic. Microfabrics: see Figure 4; $X=$ dominant microfabric; $x=$ secondary microfabric; - = absent. Individual dimensions (Ind. Size; height $\times$ width) are given for a single buildup, e.g., one hemispheroid. When no buildup can be individualized the, size is und = undetermined. Stratal geometry and dimensions are the thickness and the lateral extension of a series of buildups with the same macrofabric. Disruption (biologic, hydrodynamic, and/or diagenetic) of lamination/clots is based on a visual estimation: $0=$ undisturbed; $+=$ low disturbance; $++=$ medium disturbance; $+++=$ high disturbance. The paleoenvironment column indicates: (1) the depositional domain (subtidal to supratidal) and (2) the associated depositional environment. 


\section{Microbialite Associations and Fabrics}

\subsection{Previous Interpretations}

Two paleoenvironmental interpretations were previously proposed for TCC microbialites. In the Sorbas Basin (Figure 1C), a first group of researchers proposed that the microbialites developed in a normal marine environment $[25,33,52]$. This hypothesis was based on the co-occurrence of microbialites and of normal marine organisms including red algae, echinoderms, and small coral reef patches (dominated by the coral genus Porites). Similarly, the work in [53] described red algal crusts on thrombolites and Porites-Tarbellastrea patch reefs, respectively, within TCC's DS2 and DS3 in the Las Negras area. Porites-microbialites' intergrowth was also observed in Santa Pola [54], and sedimentological evidence for normal marine conditions was found in other TCC locations $[23,24,26]$. However, parts of the TCC, especially the last depositional sequence (DS4), showed evidence of fluctuating salinity, e.g., euryhaline faunas such as the ostracod Cyprideis and evaporite pseudomorphs [27]. Based on similar observations, some studies postulated that TCC microbialites developed in conditions alternating between normal marine and hypersaline $[24,26,32,53]$. In this work, we defined eight microbialite macrofabrics (Table 1 ) constituting two recurrent associations, namely Microbialite Association 1 (MA1) and Microbialite Association 2 (Figure 5). The latter was subdivided into MA2a and MA2b.

\subsection{Microbialite Association 1: Low Energy, Hypersaline}

\subsubsection{Description}

Stratal pattern, macro- and meso-fabrics: The microbialites of MA1 (Figures 6-9) were linked to form wide, continuous, and tabular beds tens of meters to several kilometers in length displaying a low basinward dip $\left(0\right.$ to $\left.5^{\circ}\right)$, when undeformed. The bed thickness progressively increased from a few centimeters in the proximal position up to several meters in the distal part of the platform.

The macrofabric of MA1 ranged from planar laminites (Pl; Table 1) to low relief forms, such as large hemispheroids (H1; Table 1; Figure 6A-C). When MA1 developed on a wide area, such as in Cariatiz's DS4 (Figure 3), a morphological gradient could be observed along a distal-to-proximal profile (Figure 5A). The more distal forms exhibited a planar lamination ( $\mathrm{Pl}$; Table 1) and could extend laterally for several hundreds of meters. They were occasionally interbedded with mud-rich carbonates (mudstone to packstone), containing rare miliolids, gastropods, bivalves, or ostracods. Landward, they passed to large hemispheroids reaching up to $1.5 \mathrm{~m}$ in height and $2 \mathrm{~m}$ in width (H1; Table 1, Figure $6 \mathrm{C}$ ). The size of domes progressively decreased to decimeters in proximal settings (H2; Table 1 , Figure $6 \mathrm{D}$ ). The most proximal morphologies were small hemispheroids, crinkles, and wavy laminites $(\mathrm{H} 3, \mathrm{C} i$, and $\mathrm{W}$; Table 1; Figures 5A and 6E-H). In the northern part of the Sorbas Basin (e.g., Cariatiz; Figure 3; see also [25]), stromatolite crusts molding siliciclastic and carbonate pebbles to cobbles (Cr1; Table 1; Figure 7A-D) were found in the proximal part of the platform. These microbialites occasionally showed a rippled surface (Figure 7B,C). In the shallowest settings, the microbialites (Table 1) displayed desiccation cracks (Figure 6G,H and Figure 8), boxwork structures (Figure 7E), or lenticular gypsum pseudomorphs that locally disrupted the lamination. Microbialites were locally pierced by networks of decimeter-high vertical ducts with circular sections (Figure 7F). Most of the MA1 microbialites had a stromatolite mesofabric (Table 1), while thrombolites were less common. Some hemispheroids (H2 and H3; Table 1) were mixed and composed of a thrombolitic core wrapped by stromatolites (Figure 7G). Thrombolite crusts ( $\mathrm{Cr} 2$; Table 1), which were mostly found in the proximal part of the platform, locally displayed a poorly defined lamination (Figure $7 \mathrm{H}$ ). The thickest and most extensive microbialite bed in Sorbas (DS3; Figure 3) showed oval to rounded structures on the inside of the hemispheroids (Figure 6C). These structures were filled with calcite mixed with halite needles and undetermined bitter salts, while their periphery could be strongly cemented (Figure 6C). In Cariatiz and Santa Pola, MA1 
microbialite beds could also seal breccia formed by collapse due to the dissolution of the underlying gypsum and could be affected by growth faults (Figure 3) [27,30].

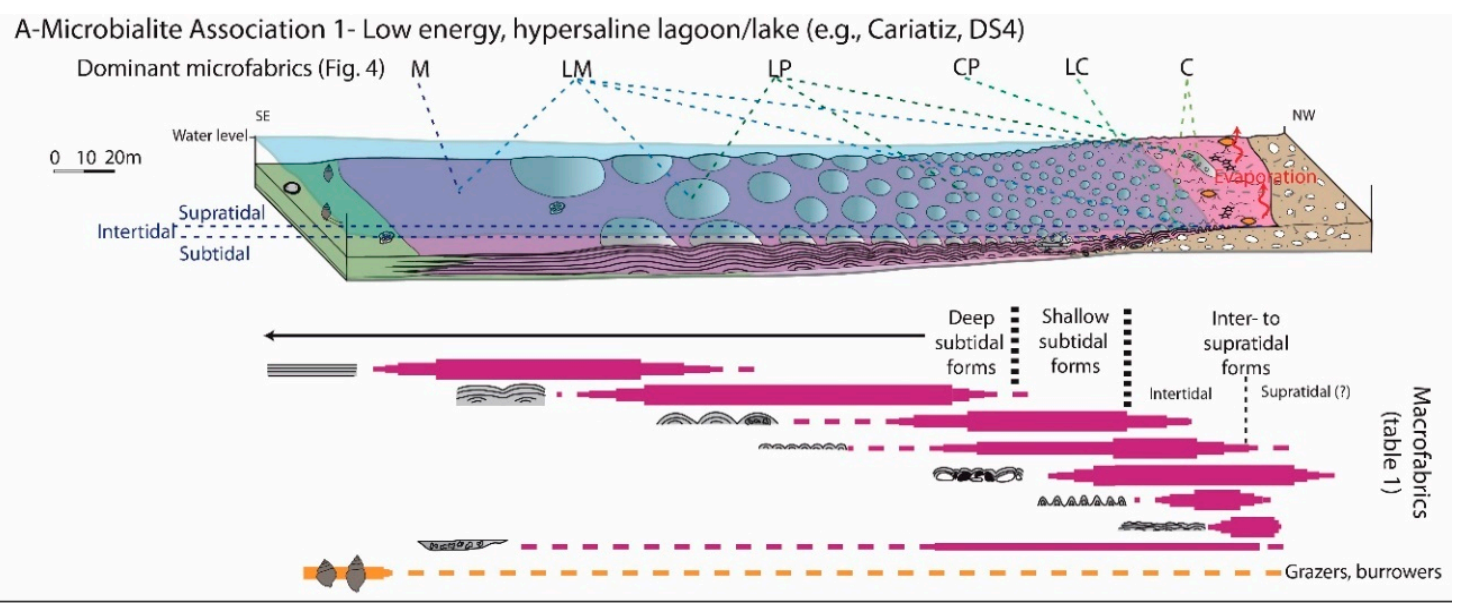

B-Microbialite Association 2a - High energy, open marine foreshore to upper shoreface (e.g., Cariatiz, DS2)

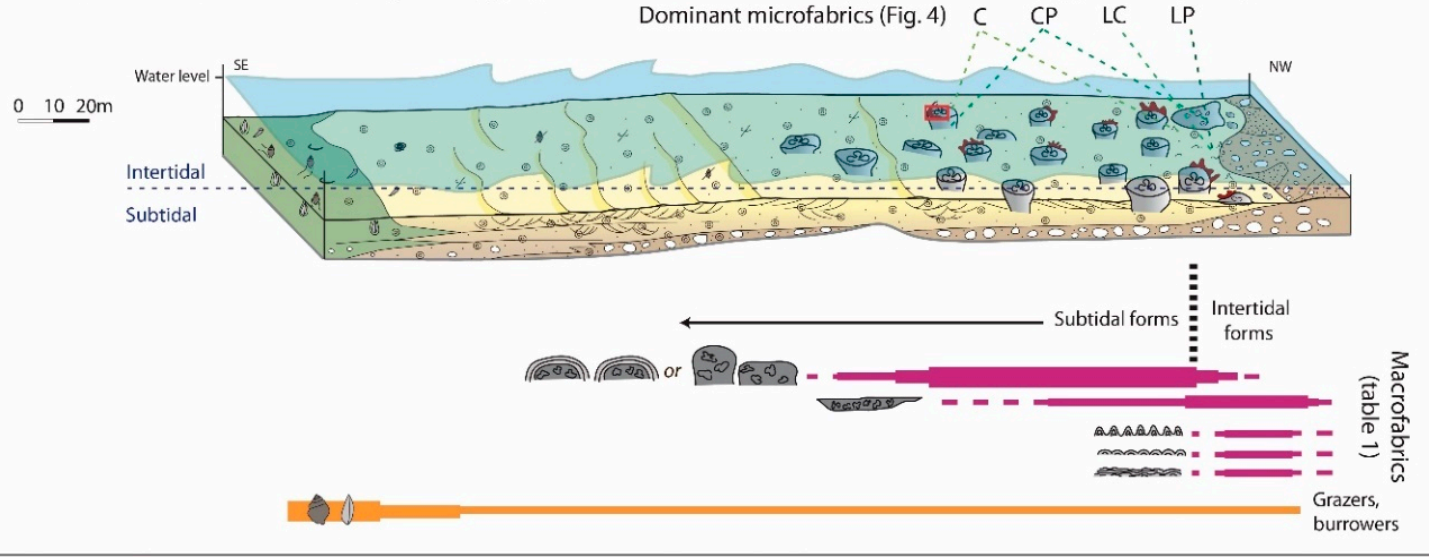

C-Microbialite Association 2b - High energy, hypersaline lagoon/lake shoreface to foreshore (e.g., Las Negras, DS4)

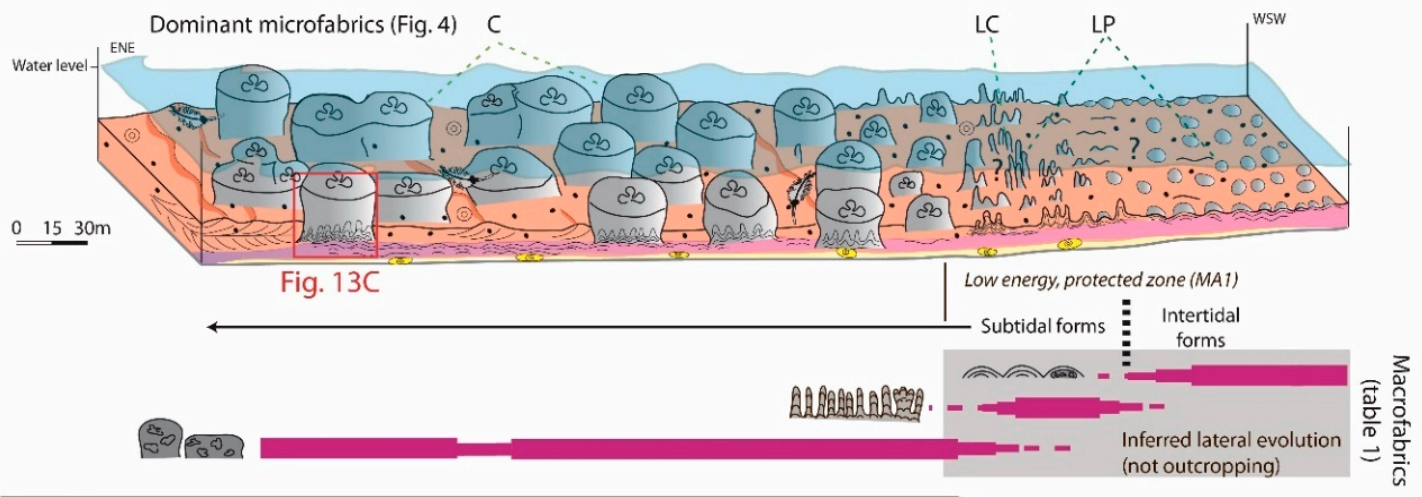

\begin{tabular}{|lllll|}
\hline Legend & Alluvial fan & Gastropods & Miliolid \\
foraminifers
\end{tabular}

Figure 5. Microbialite associations with the spatial distribution of microbialites macro-, meso-, and micro-fabrics along three depositional profiles. The position of each example is indicated in Figure 2. (A) Microbialite Association 1 (MA1) is a low energy, hypersaline lake or lagoon association. (B) Microbialite Association 2a (MA2a) is a high energy, normal marine association. (C) Microbialite Association $2 b$ (MA2b) is a high energy, hypersaline association. 

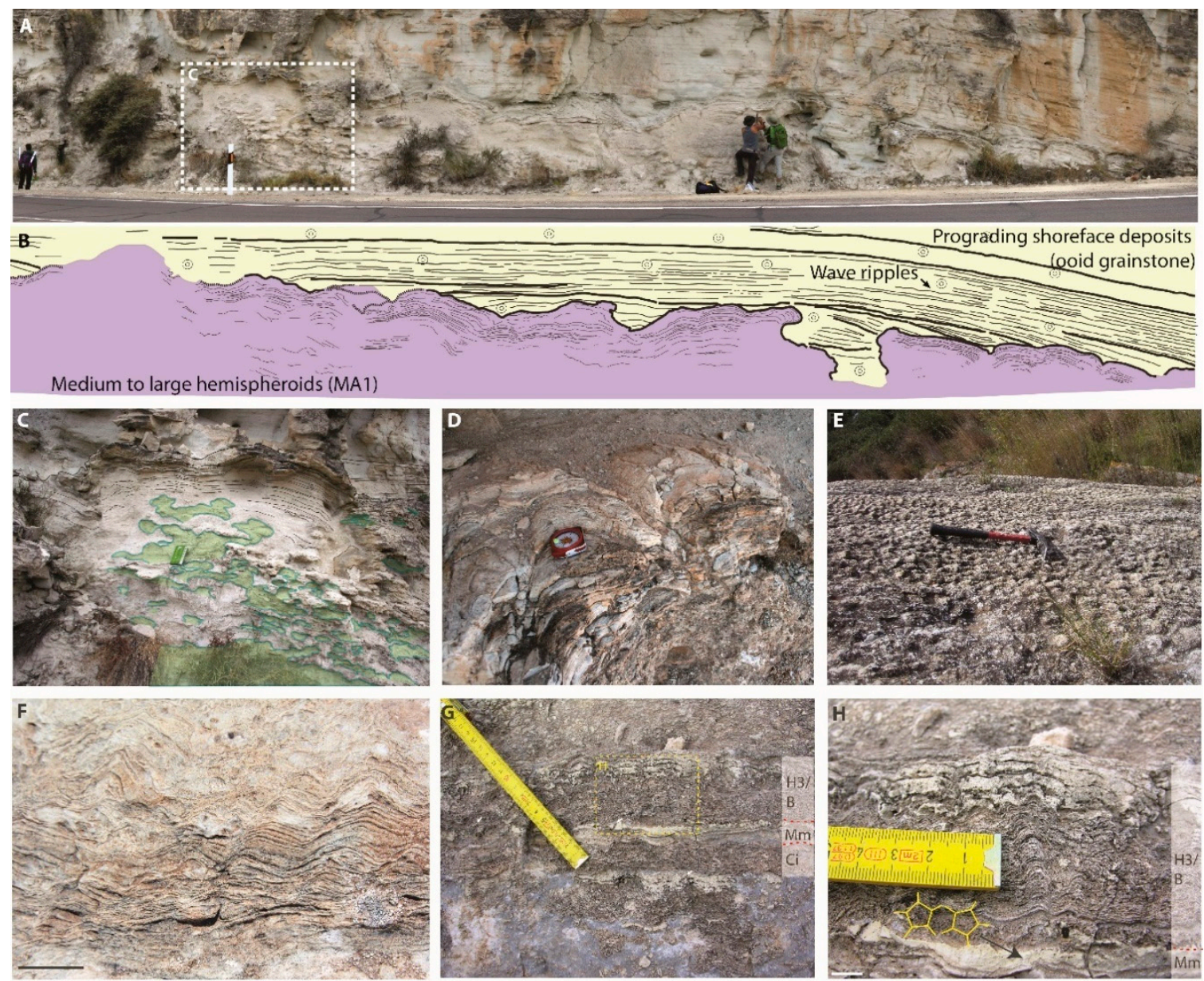

Figure 6. Macro- and mesofabrics of Microbialite Association 1 (MA1), from subtidal (A-D) to shallow subtidal/intertidal forms (E-H). (A) Photomosaic and (B) facies interpretation showing medium (H2) to large stromatolitic hemispheroids (H1). The stromatolite bed (purple) is eroded and onlapped by prograding shoreface to foreshore ooid grainstones (yellow). The locality of Sorbas, Depositional Sequence 3 (DS3). Persons for scale are $1.7 \mathrm{~m}$ tall. (C) Close-up view of (A), displaying rounded fluid circulation structures (green) inside a large hemispheroid stromatolite. (D) Oblique view of horizontally elongated medium hemispheroids. The compass for scale is $80 \mathrm{~mm}$ wide. Moras; DS4. (E) View of the surface of a bed covered by small circular hemispheroids (H3). The hammer is $40 \mathrm{~cm}$ long. Moras. (F) Small stromatolitic crinkles. Cariatiz, DS4. The scale bar is $2 \mathrm{~cm}$. (G) Intertidal succession showing crinkles $(\mathrm{C} i)$ and small hemispheroids alternating with micrite beds affected by mudcracks (Mm) indicating desiccation episodes. South of Santa Pola atoll. (H) Close-up view of (G). The hemispheroids locally show a knobby morphology. 

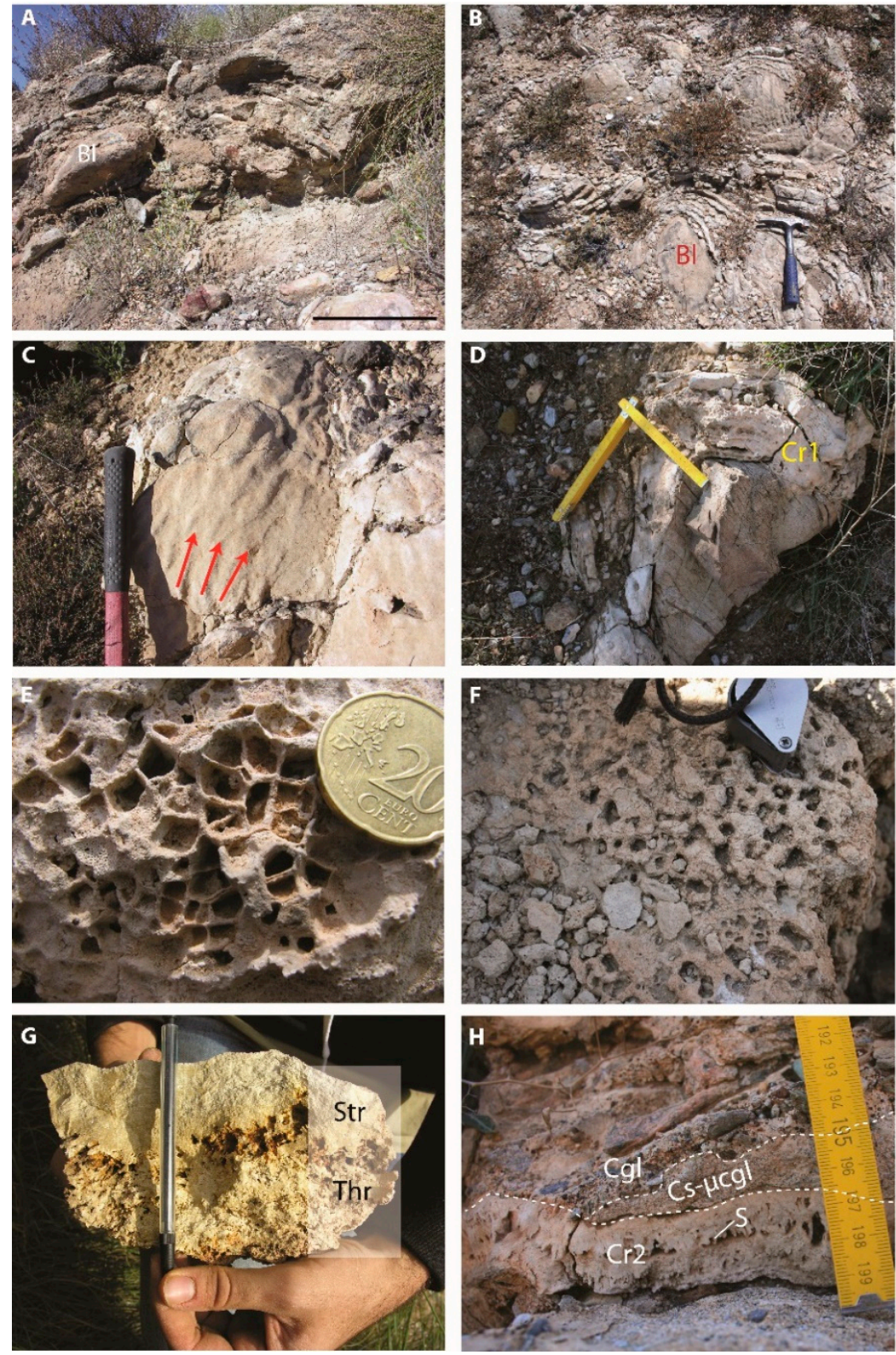

Figure 7. Macro-, mesofabrics of Microbialite Association 1 (MA1) and associated sedimentary features. (A) Stromatolitic crust on alluvial fan conglomerates $(\mathrm{Bl}=$ boulders). Cariatiz, DS4. The scale bar is $30 \mathrm{~cm}$. (B) Surface-view of a stromatolitic crust (Cr1; Table 1) encrusting boulders (Bl). Cariatiz, DS4. The hammer is $30 \mathrm{~cm}$ long. (C) Close-up view of a crust. Red arrows indicate crests of what could be wave-ripples on the stromatolite surface. Cariatiz, DS4. The visible part of the hammer is $30 \mathrm{~cm}$ long. (D) Stromatolitic crust (Cr1) on a siliciclastic boulder. The lamination is poorly defined, probably because of a strong post-depositional alteration and cementation of the microbialite. Cariatiz, DS4. One segment of the ruler is $20 \mathrm{~cm}$ long. (E) Polygonal boxwork structures interpreted as the result of evaporite dissolution atop a wavy to hemispheroid stromatolite. Cariatiz, DS3. (F) Surface view of millimeter to centimeter circular ducts cross-cutting small hemispheroids and wavy laminites on several decimeters. Cariatiz, DS4. The magnifying glass is $2 \mathrm{~cm}$ wide. (G) Section in a hemispheroid with a thrombolitic core (Thr) and a stromatolitic envelope (Str). The irregularity of the transition between the two mesofabrics is probably exaggerated by posterior dissolution. South of Santa Pola. The pencil is $14 \mathrm{~cm}$ long. (H) Thrombolitic crust (Cr2) including coarse sands (S), incised by an erosional surface covered by coarse sands to microconglomerates (Cs- $\mu \mathrm{cgl}$ ) themselves eroded by a gravel conglomerates (Cgl) Cariatiz, DS4. 

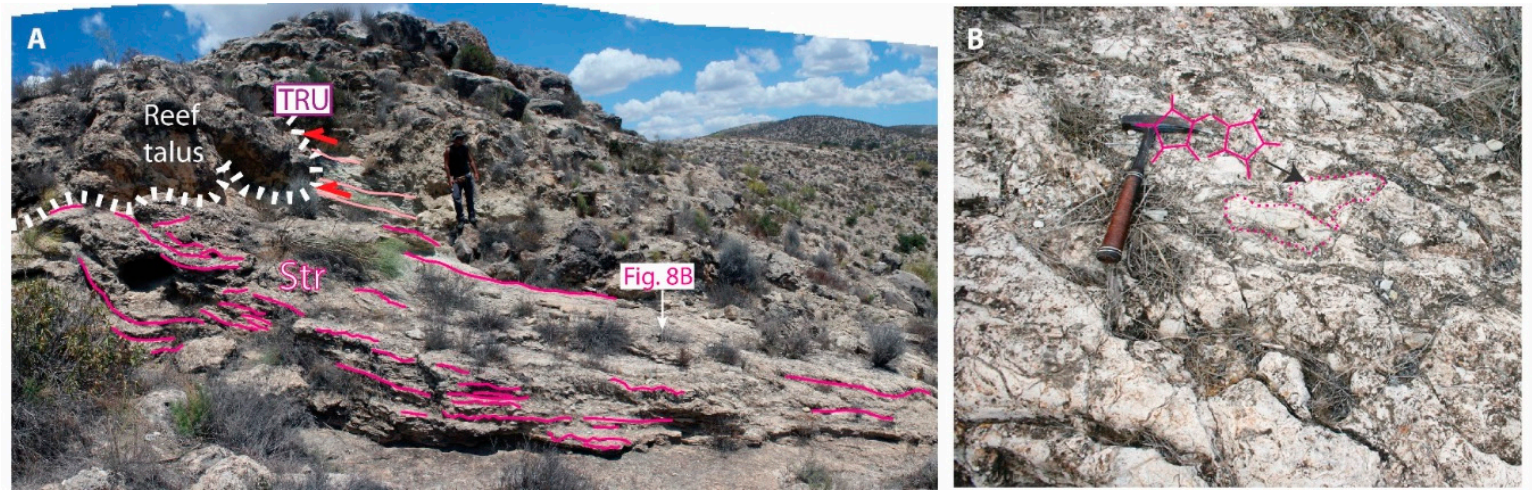

Figure 8. (A) Stratigraphic contact between the Reef Unit and the stromatolites of the Terminal Carbonate Complex (DS1); (B) close up-view of (A) showing desiccation cracks cutting the intertidal stromatolites. Locality of Moras.

Microfabrics: The six microfabrics defined in this study (Figure 4) were found in MA1 (Figure 9). The micritic (M) microfabric was composed of almost pure micrite, with no or very discrete lamination and a fenestral porosity that occasionally reached a few millimeters in width or diameter (Figure 9A). Some stromatolites displaying a well-defined lamination macroscopically showed unlaminated $\mathrm{M}$ fabric in thin section. Laminated micritic (LM) microfabric was composed of micrite organized in lamina. The thickness of lamina ranged from a few tens of microns to a few millimeters, and horizontal fenestral porosity was occasionally preserved between lamina (Figure 9A). The laminated peloidal (LP) microfabric consisted of tens to hundreds of microns thick dense micritic lamina alternating with thicker peloidal lamina (Figure 9B,C). The clotted peloidal (CP) microfabric was comprised of tens to hundreds of microns rounded to bushy peloid aggregates (Figure 9D,G; see also Table 2 and Section 7) with little or no lamination. The laminated calcarenitic (LC) microfabric was made up of an alternation between tens to hundreds of microns thick micritic lamina and thicker (up to several millimeters thick) grain-rich lamina (Figure 4). The grains corresponded to carbonate allochems (ooids, fecal pellets, and more rarely, bioclasts) and/or siliciclastic particles (mostly quartz, muscovite, and chlorite; Figure 9E,F). Peloids were also observed within grain-rich lamina. The calcarenitic microfabric was predominantly composed of allochems and siliciclastic particles (same types as LC), alternating with scarce inframillimetric micritic lamina (Figures 4 and 9E,F).

MA1 showed significant spatial variations in the nature of allochems and siliciclastic grains (Figure 9; Table S2). The pure carbonate microbialites found in Santa Pola (Figure 6G,H, Figures 7G and 10; Table S2) showed M, LP, LM, and CP microfabrics. In Las Negras, microbialites were predominantly composed of carbonate with a small proportion of volcanoclastic particles (Table S2). They mostly exhibited LP and LM microfabrics. Microbialites from the Sorbas Basin commonly displayed mixed carbonate-siliciclastic microfabrics LC and C. In these microbialites, siliciclastics could account for more than $25 \%$ of the volume (Figure 10 and Table S2). In Cariatiz, the six microfabrics were observed in various microbialites from the same bed. In this case, microfabrics showed a pronounced proximal-to-distal contrast (Figure 5A). C, LC, and CP microfabrics were found in proximal forms: crinkles, small hemispheroids, wavy laminites, or crusts (Table 1). LP and LM were ubiquitous, while $\mathrm{M}$ microfabrics were only found in distal planar laminites. Micro-encrusters were relatively scarce in MA1 microbialites. Tubular structures, 0.5 to $2 \mathrm{~mm}$ in section, locally encrusted the mixed thrombolitic/stromatolitic crust (Figure 9D). 
A

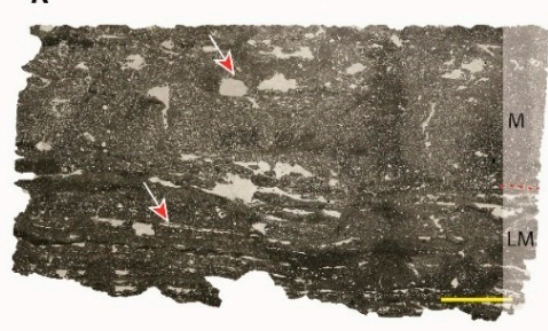

B
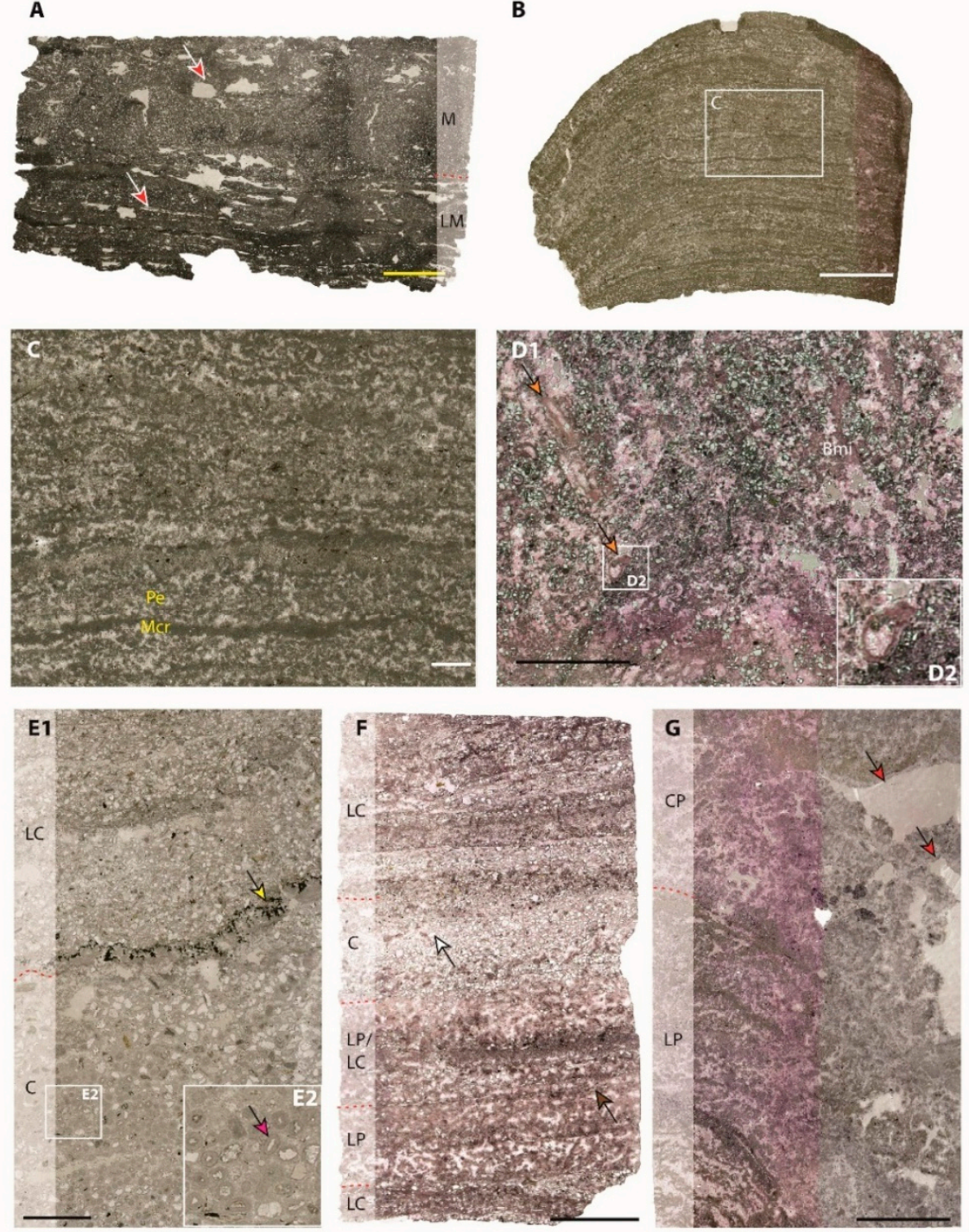

Figure 9. Microfabrics of the Microbialite Association 1 (MA1). (A) Section in planar laminites (Pl; Table 1) with a laminated micritic microfabric (LM; Figure 3) passing upward to a micritic microfabric (M; Figure 3) with large fenestral porosity (red arrows). Cariatiz, DS4. The scale bar is $5 \mathrm{~mm}$. (B) Section of a medium hemispheroid (H2; Table 1). Cariatiz, DS4. The scale bar is $1 \mathrm{~cm}$. (C) Close-up view of (B), showing a laminated peloidal microfabric (LP; Figure 3) made of alternating micritic (Mcr) and peloidal laminae (Pe). The scale bar is $1 \mathrm{~mm}$. (D1) Thin section of a highly cemented mixed thrombolitic/stromatolitic crust (Cr1; Table 1) with an upward branching clotted peloidal (CP; Figure 3) microfabric, rich in siliciclastic particles. Undetermined encrusters (algae?; orange arrows) developed on the clots. Cariatiz, DS4. The scale bar is $1.5 \mathrm{~mm}$. (D2) Close-up view of (D1) showing the undetermined encrusters. (E1) Stromatolitic crust (Cr1; Table 1) showing a calcarenitic microfabric (C) passing upward to a laminated calcarenitic microfabric (LC). This microbialite is essentially composed of trapped ooids (pink arrow; (E2)) cemented by sparite. The central dark lamina (yellow arrow) could correspond to Fe or Mn oxides and sign an interruption in stromatolite growth. Cariatiz, DS4. The scale bar is $5 \mathrm{~mm}$. (F) Complex vertical changes in a small hemispheroid/wavy laminites bed (H3/W; Table 1). Laminated (LC; Figure 3) and non-laminated calcarenitic (C; Figure 3) intervals rich in silt to fine sands: quartz (white arrow) and/or micas (brown arrows) alternate with laminated peloidal (LP) intervals. Th scale bar is $4 \mathrm{~mm}$. (G) Partial view of a small hemispheroid (H3; Table 1) with a poorly defined stromatolitic mesofabric and a laminated peloidal microfabric (LP) at the base passing upward to a clotted peloidal (CP) microfabric. Large unfilled porosity (red arrows) indicate intense secondary dissolution. The scale bar is $5 \mathrm{~mm}$. 


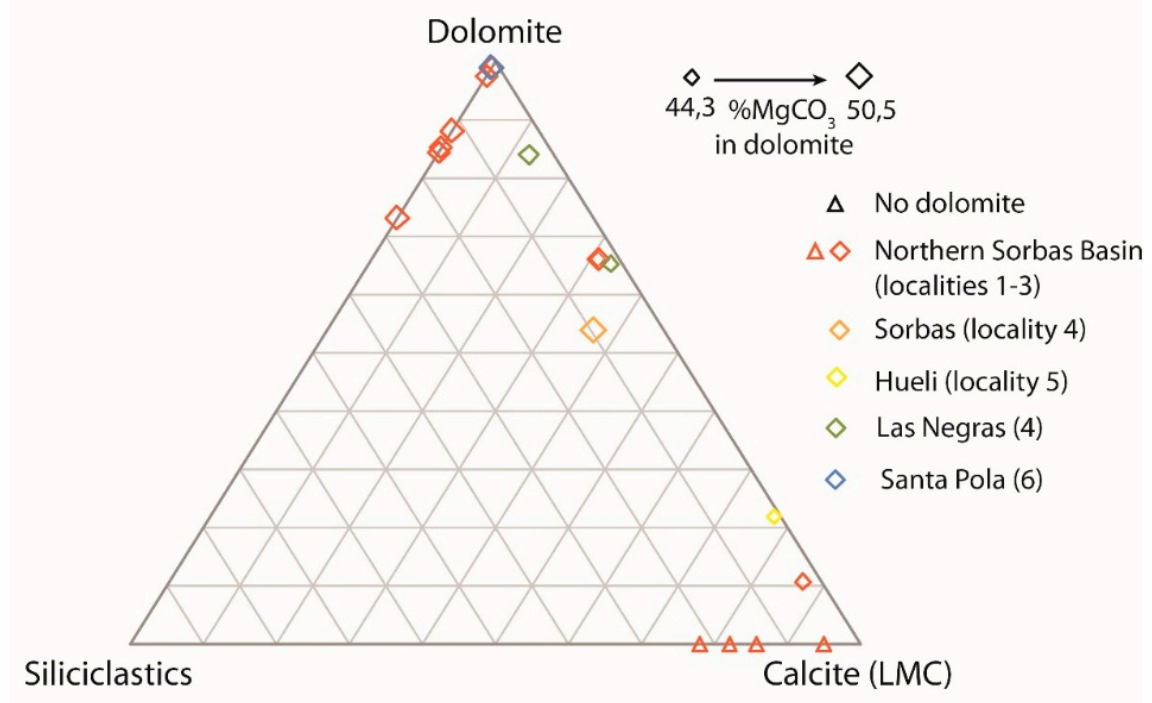

Figure 10. Mineralogical composition of the studied samples represented on a ternary plot dolomite-calcite-siliciclastics. The size of the diamonds is proportional to the $\% \mathrm{MgCO}_{3}$ in the dolomite. The sampled localities are reported in Figure 1A. Details on the mineralogy can be found in Table S2.

\subsubsection{Paleoenvironmental Interpretation}

The scarcity of mobile sediment deposited in between MA1 buildups was probably due to low concentrations of suspended allochems and detrital particles. In these conditions, the low synoptic relief of microbialites could be explained by good light availability. The poorly diversified, euryhaline fauna combined with abundant microbialites pointed to environments of salt lakes to hypersaline lagoons [15]. The absence of high energy sedimentary features and of microbialite breaking and reworking indicated that MA1 essentially developed in a low to moderate energy environment.

The distal domain of the lake (or lagoon) was characterized by continuous planar microbial laminites and large, flat hemispheroids ( $\mathrm{Pl}$ and $\mathrm{H1}$; Table 1 and Figure 5A). The shallow subtidal zone was dominated by medium to small hemispheroids and stromatolitic crusts (H2, H3, Cr1; Table 1 and Figure 5A). The intertidal zone showed the highest macro- to micro-fabric diversity, being covered with small hemispheroids, stromatolite crusts, crinkles, or wavy microbialites ( $\mathrm{H} 3, \mathrm{Cr} 1, \mathrm{C} i, \mathrm{~W}$; Table 1 and Figure 5A). Desiccation cracks (Figure 6G,H, and Figure 8) indicated intermittent exposure of the lake margins. Evaporitic conditions that developed at the periphery of the lake/lagoon were testified by the presence of gypsum inside microbial mats $[27,46]$. These lakes could also periodically be surrounded by mangrove-type vegetation, as indicated by the presence of vertical structures that could be related to pneumatophores piercing the microbial mats (Figure 7F), as documented by [15] in modern hypersaline lagoons from Cuba.

The diversity of microbialite microfabrics (Figures 4 and 5A) likely reflected differences in the relative intensity of grain trapping and binding versus microbial induced/influenced precipitation in MA1 microbialites [19,55]. Microfabrics dominated by micrite and peloids (M, LM, LP; Figure 4) were predominantly formed by microbial precipitation with secondary trapping and binding. In grain-rich microfabrics (LC or C; Figure 4), trapping and binding would at least be equivalent to, or even greater than, microbially mediated precipitation. The imbalance between the two processes could partly depend on local conditions, especially the flux of allochems and detrital grains. In areas with greater detrital input (e.g., Cariatiz, Góchar), intertidal to shallow subtidal microbialites showed either: (1) both modes of accretion, as indicated by alternating sand to silt-rich and micritic or peloidal laminae (e.g., Figure 9F), or (2) micritic or peloidal laminae indicating microbially induced/influenced precipitation (Figure 9A-C; see also [25]). Trapping and binding may be locally significant, especially in intertidal to shallow subtidal microbialites, and decrease basinward together with the diminishing detrital flux (Figure 5A). In contrast, deep subtidal stromatolites from the Sorbas Basin (e.g., Cariatiz, 
Sorbas; Figure 3) were dominated by peloids and micrite (Figure 9A), indicating that they were mostly formed by microbially induced/influenced precipitation. Microbially induced/influenced precipitation predominated in both shallow and deeper microbialites in areas devoid of siliciclastic inputs, such as Santa Pola (Figure 3).

\subsection{Microbialite Associations $2 a$ and 2b: High Energy, Normal Marine to Hypersaline}

\subsubsection{Description}

Stratal pattern, macro- and meso-fabrics: MA2 microbialites (Figure 5B,C, Figures 11-13) were included within ooid, pellet, and/or siliciclastic sand beds. These beds, 1 to $4 \mathrm{~m}$ thick, extended over several hundreds of meters laterally and showed 0 to $25^{\circ}$ dipping sedimentary slopes (Figures 3 and 12 ). Isolated microbial buildups or patches of fused buildups developed mostly on platform highs, generally over the paleo-reef flat and upper slope (e.g., Cariatiz, Góchar, Las Negras, Santa Pola; Figure 3). In paleotopographic lows, buildups may have fused to form larger structures [50].

The most abundant macrofabrics in MA2 were columns and stacked hemispheroids (Co and SH; Table 1 and Figure 5B,C). MA2a columns developed within cross-bedded ooid or mixed grainstones to rudstones (Figure 11A-C and Figure 12). Columns had vertical to sub-vertical flanks and could exhibit stocky to elongated morphologies (Figure 11C,E) or display "mushroom" shapes (Figure 11B). Columns and stacked hemispheroids (Co and SH; Table 1) displayed either a thrombolitic core wrapped in a stromatolitic envelope (Figure 12D) or were fully thrombolitic (core and envelope; Figure 11E). Thrombolitic crusts (Cr2; Table 1 and Figure 5B), as well as crinkles (Ci) and wavy (W) stromatolites also occurred in MA2. Complex successions of borers and encrusters commonly developed at the top or on the flanks of buildups (Figure 11D,F-H). Branching red algae (Figure 11G,H) and vermetids were the most common encrusting and bioeroding groups, respectively [25,46]. MA2b (Figure 5C) included small $\mathrm{cm}$ to $\mathrm{dm}$ high stromatolite branches (B; Table 1), which developed within a pellet packstone (Figure 13A,C,E). Branches formed the base of large columns also included within cross-bedded pellet and ooid grainstones (Figure 13B,C). The largest columns, $4 \mathrm{~m}$ thick by $3.5 \mathrm{~m}$ wide, were measured in Las Negras DS4 (Figure 3), though larger buildups were previously described in the same area [53]. Overall, columns were dominantly thrombolitic (Figure 13A-C), although well-defined laminated zone could alternate with or pass laterally into clotted zones, such as in Hueli (Sorbas Basin; Figure 1B). The upper intercolumn space could be filled with mollusk and pellet floatstones (Figure 13D) or ooid grainstones.

Microfabrics: Grain-rich microfabrics, LC and C (Figure 4), were predominant in columns (Phase 0 in Figure 11G). They were also common in thrombolitic crusts associated with LP microfabric. Branches showed LP and LC microfabrics (Figure 13E,F), while stacked hemispheroids had a C or LP microfabric in the core and C, LC, and/or LP microfabric at the periphery (Table 1). Various types of grains were observed within microbialites, and their composition varied between localities (Figure 10). In the northern part of the Sorbas Basin, siliciclastic particles dominated by quartz grains could account for up to $15 \%$ of the microbialite volume (Figure 11G,H and Table S2). Ooids were common in Sorbas and Hueli, while bioclasts were scarce overall. Pellets and ooids were found abundantly in Las Negras (DS4; Figure 2), either incorporated as laminae inside branches (Figure 13E,F) or as the main constituent of large thrombolitic columns, where they showed no particular organization. Pellets differentiated from peloids in shape, i.e., they were ovoid and showed a sharp border, and size, commonly reaching more than $1 \mathrm{~mm}$ in length (Figure 13F). 

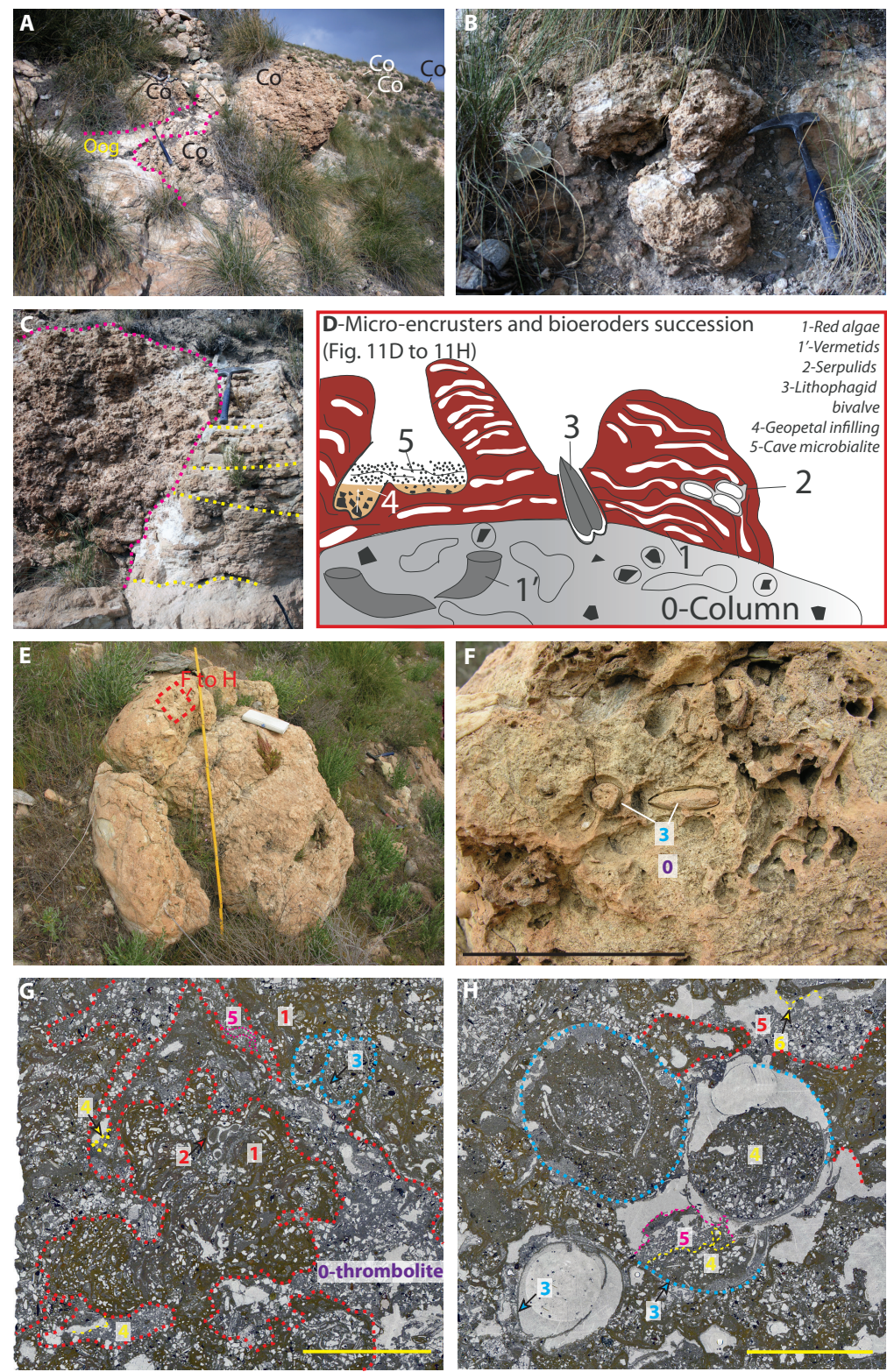

Figure 11. Macro-, meso-, and micro-fabrics of Microbialite Association 2a (MA2a). (A) Thrombolitic columns (Co; Table 1) in an ooid shoal grainstone (Oog). Cariatiz, DS2. The hammer is $35 \mathrm{~cm}$ long. (B) "Mushroom"-shaped column in the same ooid grainstone. Cariatiz, DS2. The hammer is $35 \mathrm{~cm}$ long. (C) Large column showing a clotted, thrombolitic mesofabric, in an ooid grainstone. The layering of ooid grainstones can be followed inside the columns, indicating that their deposition was contemporaneous with microbialite development. The hammer is $35 \mathrm{~cm}$ long. Cariatiz, DS2. (D) Sketch of the micro-encruster and bioeroder succession observed in MA2a microbialites. (E-H) Succession ( 0 to 5 ) of encrusters (red numbers), borers (blue), internal sediment, and cements (yellow) on and inside a thrombolitic crust. Cariatiz, DS3. (E) The crust covers a thrombolitic column. The ruler is $1.4 \mathrm{~m}$ long. (F) The crust (0) is bored by bivalves (3; Lithophaga sp.?). Scale bar is $5 \mathrm{~cm}$. (G) The crust (0), showing a calcarenitic microfabric, is encrusted by branching red algae (1) alternating with serpulids (2) and bored by bivalves (3). Red algal and microbialite fabric porosity are filled up with geopetal sediments (4). The inter-branches space is finally filled with a laminated peloidal microbialite crust (5). The scale bar is $5 \mathrm{~mm}$. (H) Large borings (3; blue dotted line) are successively infilled with geopetal sediment (4) and a second, cryptic microbialite generation (5; pink dotted line). Finally, a pendant vadose calcite cement (6-Pc) precipitates in the secondary, solution porosity (yellow dotted line). The scale bar is $5 \mathrm{~mm}$. 


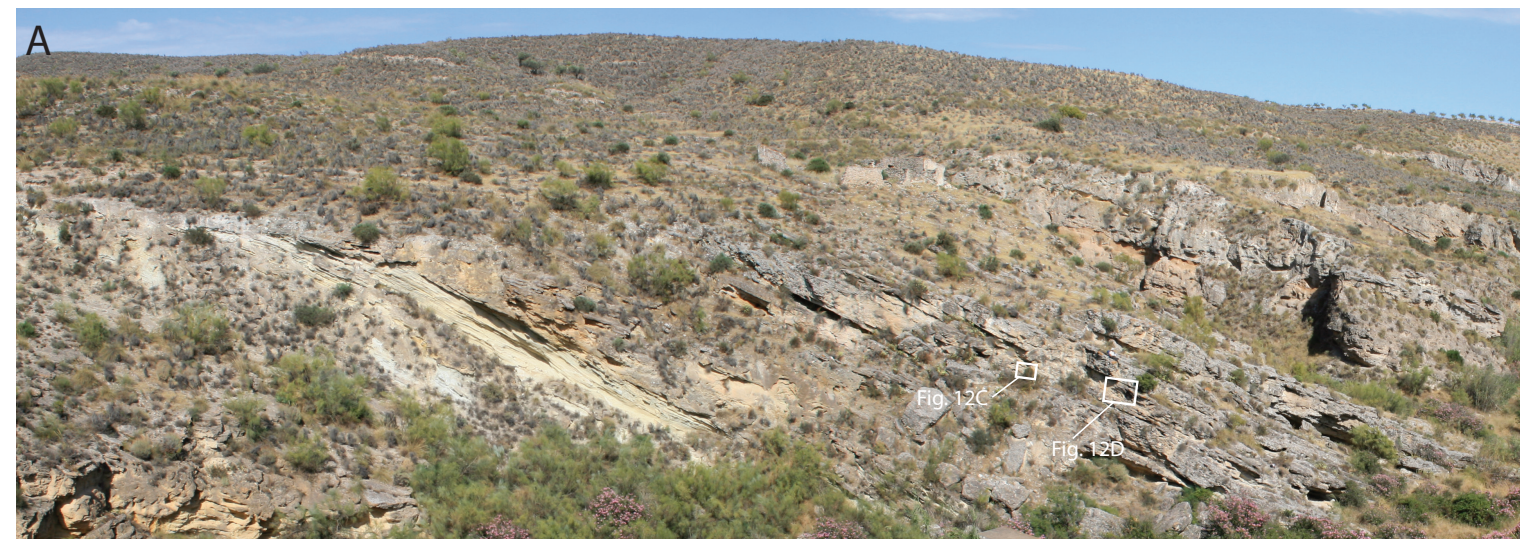

B
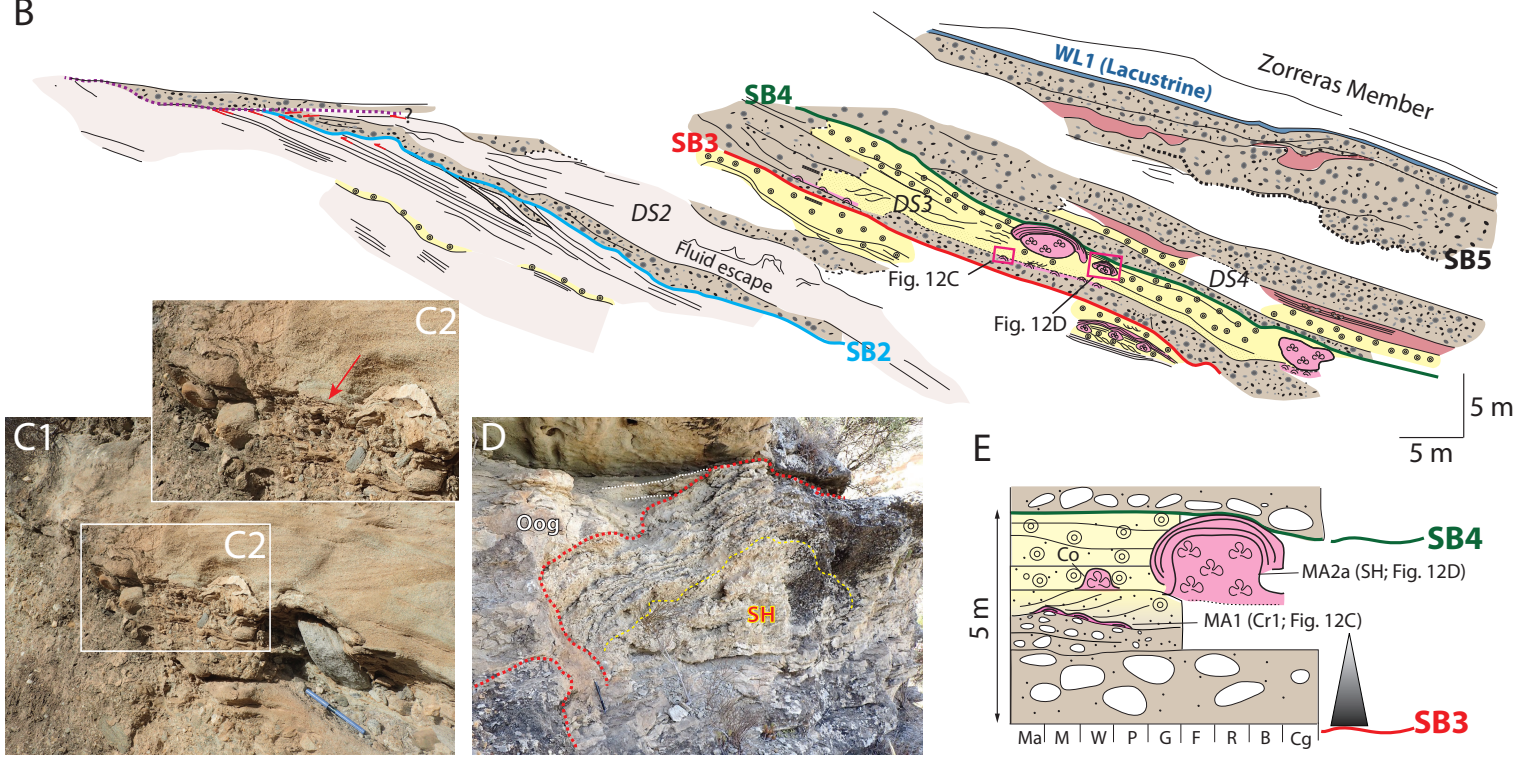

\begin{tabular}{|c|c|c|c|c|c|}
\hline Lege & nd & $\begin{array}{l}\text { Siltite/fine arenite/ } \\
\text { carbonate muds }\end{array}$ & ${ }^{* \text { OOid grainstone }{ }^{* * *} \text { Arenite }}$ & 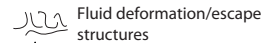 & $\longleftarrow$ Onlaps $<$ Toplaps \\
\hline 0 & $\begin{array}{l}\text { Conglomerates } \\
\text { Alluvial fan }\end{array}$ & Mudflat to shoreface & Foreshore, up. shore & Normal grading & $\begin{array}{ll}\text { Textures } & \text { G: grainstone } \\
\text { Ma: marl } & \text { F: floatstone }\end{array}$ \\
\hline & $\begin{array}{l}\text { Red siltstone } \\
\text { to claystone } \\
\text { Floodplain }\end{array}$ & 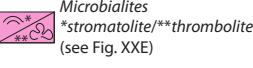 & $\begin{array}{l}\text { Mudstone to oncoid rudstone } \\
\text { Freshwater lake }\end{array}$ & $\begin{array}{l}\text { SBy Sequence Boundary } \\
\text { SS3 } \\
\text { 4h order depositional sequence } \\
\text { SBX Sequence Boundary }\end{array}$ & $\begin{array}{l}\text { M: mudstone R: rudstone } \\
\text { W: wackestone B: bindstone } \\
\text { P: packstone Cgl: conglomerate }\end{array}$ \\
\hline
\end{tabular}

Figure 12. Stratigraphic architecture of the TCC and microbialites occurrences in the Rambla de Góchar. (A) Photomosaic and (B) interpretation of the geometry and facies of the southern part of the TCC outcrop in the Rambla de Góchar. (C1) Close-up view of (A) and (B) showing a stromatolite crust (red arrow) covering alluvial fan conglomerates. The crust itself is overlain by a dune composed of arenites. The pencil for scale is $15 \mathrm{~cm}$ long. (C2) is an enlargement of (C1) showing the laminated mesofabric of the crust. (D) Close-up view of (A) and (B) showing a large stacked hemispheroid (SH) surrounded by ooid grainstones (Oog; white dotted lines). The pencil for scale is $15 \mathrm{~cm}$ long. (E) Synthetic sedimentary section of Depositional Sequence 3 in the Góchar area, with relationships between the microbialite associations and other sedimentary deposits.

\subsubsection{Paleoenvironmental Interpretation}

Both the structure and the composition of the sediment trapped inside and deposited between microbialites indicated a high energy, wave and locally tide dominated environment with permanent and intense sediment motion. Columns and branches did not show evidence of growth interruption related to long periods of subaerial exposure, indicating they mostly grew in a subtidal setting (Figure 5B,C). The high relief of the columns characterized a strong vertical accretion that: (1) indicated a high accommodation space, up to several meters of water depth $[17,56]$, and (2) could prevent burial 
by mobile sand dunes [57]. The local continuity between the peripheral sediment and microbialite internal boundaries (Figure 11C) and the presence of microbialite fragments in peripheral sediments could be related to episodes of abrasion and erosion by wave and/or currents. Branches were elongated and laminated, containing few trapped pellets, while columns were generally stocky, thrombolitic, and richer in grains. Therefore, we postulated that branches developed in lower energy, protected environments, whereas columns were exposed to waves. Thrombolitic crusts had a lower relief and probably grew in intertidal to shallow subtidal areas with lower accommodation space and/or higher wave abrasion [58]. As for MA1, crinkles and wavy stromatolites were interpreted as intertidal microbialites.

The observation of lamination passing laterally to clots in some columns or crusts indicated that a part of the thrombolitic fabrics may derive from the alteration of an original stromatolitic fabric. Such a disturbance could be due to a high encrustation rate. For example, the development of macroalgal holdfasts [59] or the presence of naked foraminifera inside microbialites [60] may have disturbed the original lamination and led to the formation of thrombolites. Alternatively, fan-shaped arrangements of filamentous cyanobacteria precipitating carbonates and subsequent heterotrophic bacterial degradation of organics coupled with carbonate dissolution [61] could form the clotted fabric.

The trapping and binding of particles is a major process in column and crust accretion. The nature of the trapped sediment is variable and highly depends on local sources. Columns incorporated siliciclastics (Figures 10 and 11G,H) and ooids in the Sorbas Basin or fecal pellets in Las Negras. Branches showed a laminated peloidal microfabric (Figure 13E,G) sometimes interrupted by lamina of trapped fecal pellets (Figure 13E,F), which was interpreted as the result of the alternation of microbially influenced/induced precipitation (dominant) and trapping and binding processes.
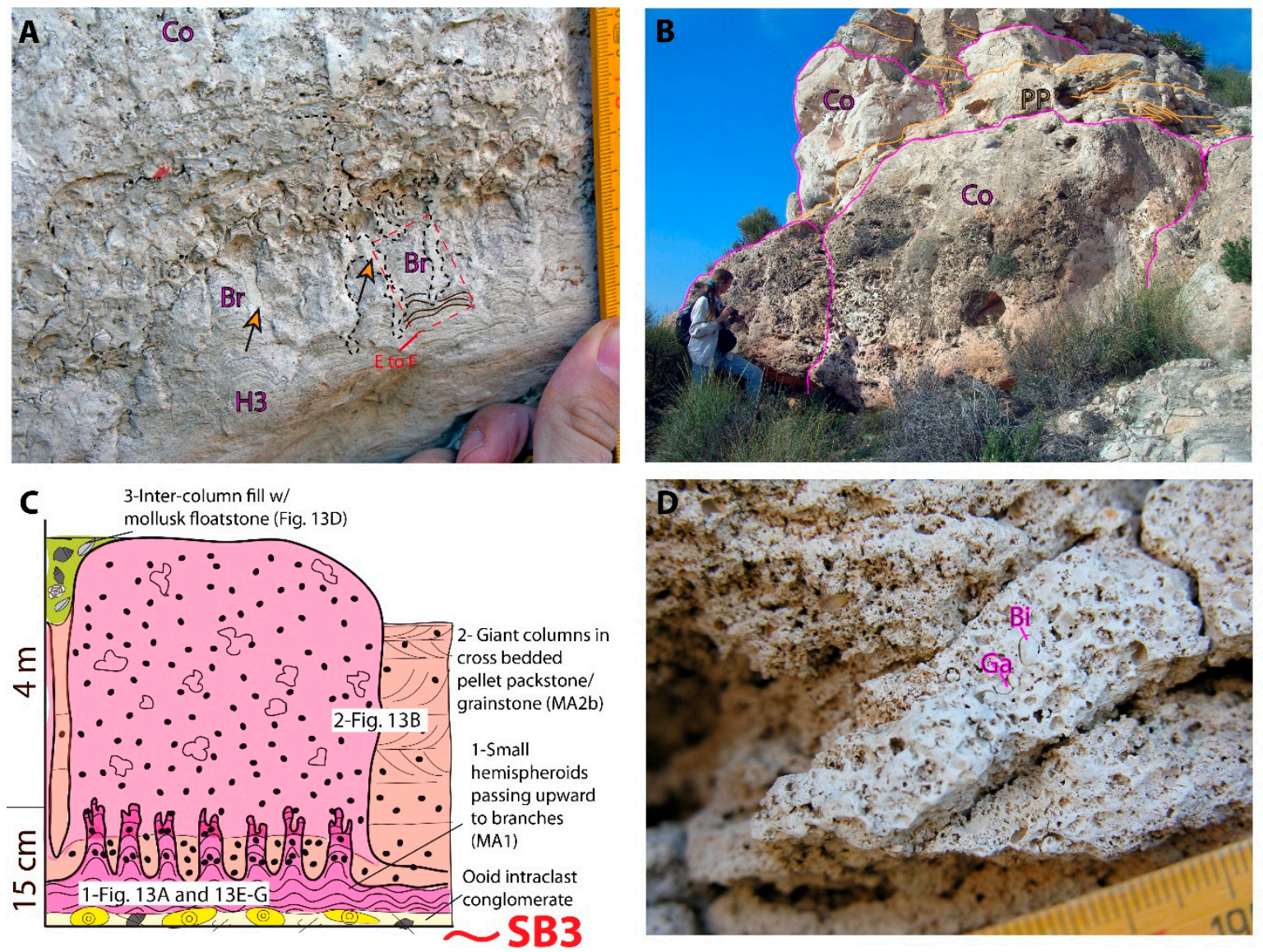

Figure 13. Cont. 

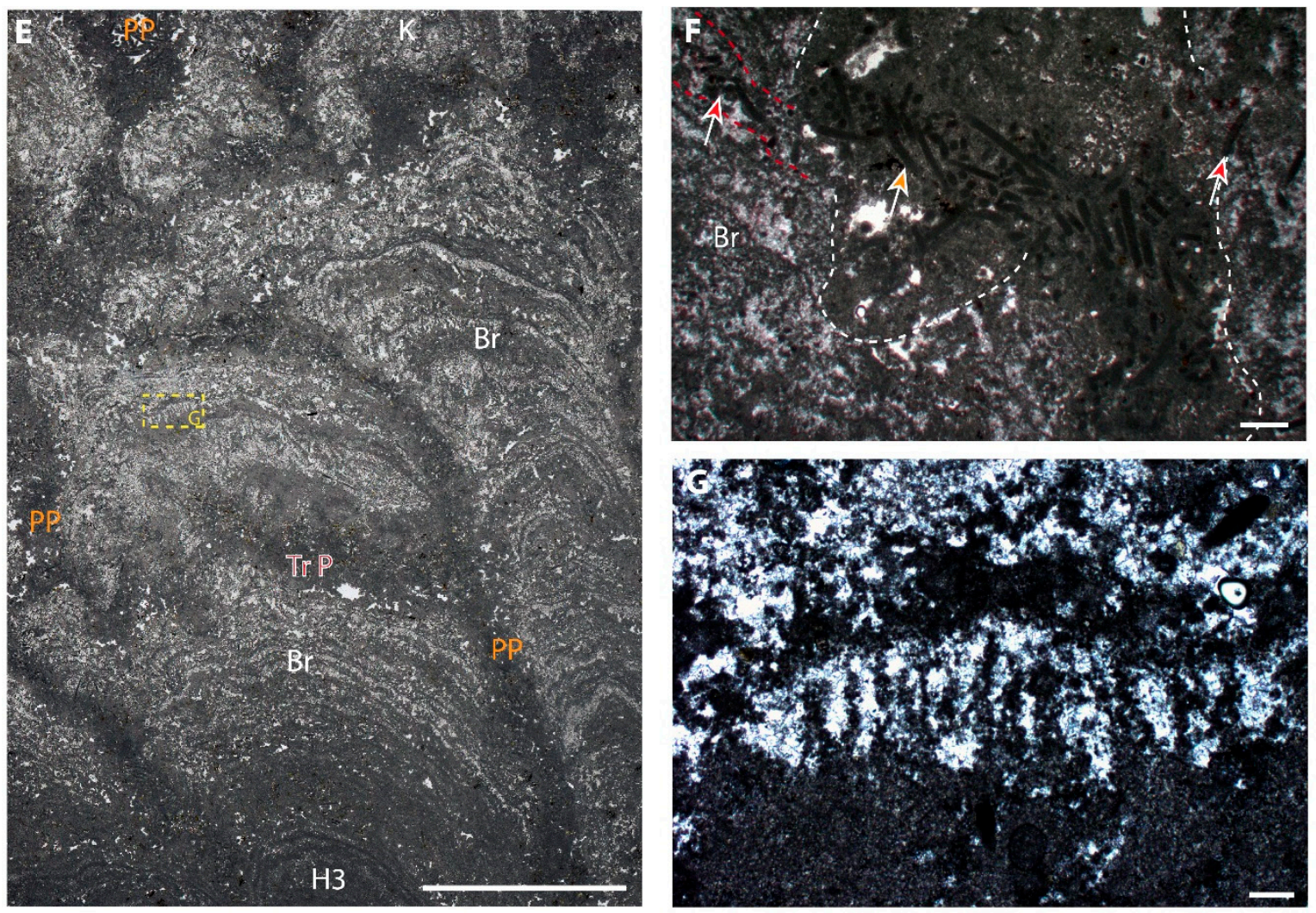

Figure 13. Illustration of Microbialite Association 2b in Las Negras, DS4 (see also Figures 3 and 5C). (E) and (F) are scans of a thin section of the base of the succession, as indicated in (A) and (C), while $(\mathrm{G})$ is a polarizing microscope photograph in plane polarized light. (A) The base of the microbialite bed, displaying a progressive vertical change from small, laterally links hemispheroids (H3) to branches which are subsequently included in the base of a giant thrombolitic column (Co), see (B,C). The inter-branch space was filled with a pellet packstone (orange arrows), see (F). (B) Superposition of two generations of giant thrombolitic columns (Co; pink lines). In the upper bed, columns are embedded in cross-bedded pellet packstones (PP). The person for scale is $1.8 \mathrm{~m}$ tall. (C) Synthetic cross-section of DS4 in Las Negras, showing the vertical evolution of microbialites and associated deposits. (D) Floatstone with pellets and entire mollusks ( $\mathrm{Bi}=$ bivalves; $\mathrm{Ga}=$ gastropods) filling the upper part of the space between thrombolitic columns. (E) Thin section of the transition between small hemispheroids (H3) and branches, see (A) for the location of the thin section. The inter-branch space is filled with a pellet packstone (PP). The branches display peloidal laminae alternating with trapped pellets and fine volcanoclastics laminae (TrP), forming a laminated peloidal microfabric (Figure 4). (F) Close-up view of (E), at the interface between the branch and the pellet packstone. A lamina made of trapped pellets (red arrow) can be observed inside the branch (red dotted line). The porosity of the pellet packstone is partly preserved, while the microbialite porosity is almost entirely cemented by low magnesian calcite (LMC), which may be due to early cementation. The scale bar is $500 \mu \mathrm{m}$. (G) Close-up view inside a branch (E), showing micro-columns made of dolomite peloids, probably precipitated on filamentous cyanobacteria sheaths (see Table 2). The scale bar is $200 \mu \mathrm{m}$.

Two paleosalinity ranges were inferred for MA2a and MA2b, based on the biotic associations found with microbialites. MA2a locally showed a diversified marine encruster and bioeroder succession (Figure 11D,F-H). The order of events was the following: (i) An initial encrustation, contemporaneous with the microbialite (Phase 0), was composed of alternating red algae and serpulids (Phases 1 and 2; Figure 11D). (ii) Bivalve (Lithophaga sp.?) borings (Phase 3) were indicative of a lithified substrate exposed to waves. (iii) Finally, a second generation of microbialites (Phase 5) developed in the framework cavities following a geopetal sediment infilling (Phase 4). This succession reflected the 
formation and closure of cavities inside open marine high energy buildups [62-65]. We interpreted MA2a as a shallow water $(<10 \mathrm{~m})$, high energy, and open marine association.

The biota associated with MA2b (Figure 4A) was characterized by a low diversity (i.e., gastropod and bivalve). Biological activity (e.g., grazing) was elevated, as indicated by the large quantities of trapped fecal pellets, probably that of brine shrimp. Comparable pellets are trapped inside modern microbialites from the Great Salt Lake [58]. We interpreted MA2b as a shallow water $(<10 \mathrm{~m})$, high energy and hypersaline association.

\section{Stratigraphy of TCC Microbialites}

Previous investigations by our team $[27,30]$ included detailed facies descriptions and stratigraphic interpretations of some of the studied transects (Cariatiz, Sorbas, Santa Pola, Las Negras; Figure 2). The stratigraphic section in Benejuzar (Figure 3) was simplified from [47]. We added three new localities in the current study: Góchar (Figure 12) and Moras in the northern Sorbas Basin and Hueli in the southern Sorbas Basin (Figure 1; Table S1). The four depositional sequences of the TCC (DS1 to DS4) were found in five out of eight localities (Cariatiz, Moras, Góchar, Las Negras, and Sorbas; Figure 3), allowing fine comparisons of the timing of microbialite development at a regional scale.

\subsection{Sorbas Basin}

\subsubsection{Cariatiz}

In Cariatiz, the $2 \mathrm{~km}$ long and $100 \mathrm{~m}$ deep Rambla de Los Castaños incised the TCC, the underlying Reef Unit (Cantera Mb. in the Sorbas Basin), and the overlying continental Zorreras Mb. (Figure 3). Here, we focused on the southernmost kilometer of the canyon [30]. The topography of the fringing reef substratum strongly controlled the architecture of the TCC platform. On the former reef flat, TCC was ca. $20 \mathrm{~m}$ thick and dominated by intertidal, shallow subtidal, and alluvial fan deposits, while it was at least $70 \mathrm{~m}$ thick (the base was not visible) and dominated by subtidal deposits on the former basinal diatomite-marl alternations (Upper Abad Mb.; Figure 3). During DS1, thin decametric beds of shallow water MA1 stromatolites ( $\mathrm{H} 2, \mathrm{H} 3, \mathrm{C}$, and W; Table 1) were restricted to a narrow, ca. $100 \mathrm{~m}$ wide zone (Figure 3). These stromatolites alternated with low energy mudstones and fine muddy packstones to form the transgressive part of high frequency sequences. High energy ooid or oobioclastic shoal deposits prograded over these deposits during high frequency regressions [30]. DS2 coincided with the maximum extension of the TCC platforms on the Sorbas Basin margins, and so probably with the highest water level of the entire TCC. At this time, high energy MA2 thrombolites (Figures 5B and 11) developed within ooid shoals on the former reef flat (Figure 3).

A collapse of the TCC platform initiated during DS3, following the deformation/dissolution of 30 to $40 \mathrm{~m}$ of gypsum intercalated between the Reef Unit and the TCC [30]. This deformation/dissolution resulted in the tilting and subsequent erosion of parts of the proximal deposits of DS1 and DS2 and in the formation of an angular unconformity between DS1-DS2 and DS3-DS4 (Figure 3). During DS3, shallow water MA1 microbialites (H2, H3; Table 1) were predominant and formed a few decimeter to one meter thick beds (Figure 3). In DS4, alluvial fan deposits strongly prograded southeastward. The retreat of the gypsum towards the center of the Sorbas basin led to the formation of thick collapse breccia, antiform structures, and syn-sedimentary listric faults [27]. The increasing accommodation space resulted in the local stacking of a $30 \mathrm{~m}$ thick interval of MA1 microbialites. This was the period of maximum extension of the microbialites, which formed $\mathrm{km}$ wide continuous beds from the intertidal to the deep subtidal domain (Figures 3 and $5 \mathrm{~A}$ ).

\subsubsection{Góchar}

The Rambla de Góchar (Figures 1C and 12) cut through the same stratigraphic units as the Rambla de los Castaños in Cariatiz (Figure 3). The TCC appeared as an outcrop on a ca. $300 \mathrm{~m}$ wide area, with a thickness comprised between ca. $10 \mathrm{~m}$ on the paleo-fringing reef flat (Cantera $\mathrm{Mb}$.) and ca. $60 \mathrm{~m}$ 
southward of the Reef Unit (Figure 12). A thick carbonate breccia overlying the reef paleoslopes was intercalated between the TCC and the Reef Unit. As in Cariatiz (Figure 3), an angular unconformity possibly linked with the dissolution of an underlying gypsum layer separated DS1-DS2 from DS3 or DS4 (Figure 12A,B). During TCC deposition, Góchar was also located at the periphery of a vast alluvial fan that developed on the northern margin of the Sorbas Basin [27]. Microbialites occurred mostly in DS2 and DS3. At the base of DS3, decimeter thick hemispheroidal stromatolites (MA1) draped alluvial fan conglomerates and were then eroded and covered by cross-bedded arenites (Figure 12C). These deposits were overlain by MA2a buildups consisting of meter high columns with a thrombolitic mesofabric (Co; Table 1) or in stacked hemispheroids ( $\mathrm{SH}$; Table 1), developing within high energy cross-bedded ooid grainstones (Figure 12B,D,E). SH either displayed a thrombolitic core and a laminated envelope (Figure 12D) or were fully laminated, with a centimeter-thick lamination. The sequence ended with an erosive surface (SB4). DS4 was mostly composed of alluvial conglomerates and floodplain and paleosol deposits, showing a strong progradation of the alluvial system.

\subsubsection{Moras}

Moras is located less than one kilometer east of Góchar (Figure 1C). A ca. $30 \mathrm{~m}$ high and $100 \mathrm{~m}$ wide TCC outcrop was formed by a meander of the Barranco de la Mora. The microbialites had a similar stratigraphic distribution as those in Cariatiz. A part of the transgressive deposits of DS1 was composed of a ca. $2 \mathrm{~m}$ thick MA1 bed (Figure 8). These low energy microbialites onlapped and encrusted the major erosional surface (TRU), cutting the fossil reef slopes (Figure 8A). Stromatolites (mostly H3 and W; Table 1) were impacted by desiccation cracks (Figure 8B), locally infilled by ooid grainstones, which indicated an intertidal environment. Thrombolitic columns and crusts (MA2a), sometimes covered by red algae, were locally preserved at the top of DS2. A continuous, up to $3 \mathrm{~m}$ thick MA1 layer outcropped in DS4. In this bed, large hemispheroids (H1) covered ooid grainstones and were overlain by medium (H2; Figure 6D) and then small hemispheroids (H3; Figure 6E). The upward decrease in the size of hemispheroids could reflect a decrease in the accommodation space (Figure 5A). This was followed by an erosive surface (SB5) covered by alluvial fan conglomerates, recording the lowest water level of DS4.

\subsubsection{Sorbas}

Close to the Sorbas basin depocenter (Figure 1C), the TCC reached $90 \mathrm{~m}$ in thickness. There, microbialites could only be identified in DS3 and DS4 (Figure 3). A MA1 stromatolite bed, hundreds of meters wide and up to $5 \mathrm{~m}$ thick (Figure 6A-C), formed during the maximum flooding of DS3 [27]. This bed was overlain by prograding clinoforms made up of foreshore to upper shoreface ooid grainstones (Figure 6B). In DS4, we documented thinner intertidal and shallow subtidal MA1 forms (H2, H3; Table 1) alternating with thicker lagoonal muddy deposits and thin ooid beds that could result from washover [66]. DS4 showed intertidal to shallow subtidal facies including locally gypsum pseudomorphs (Figure 3). These deposits recorded a decrease of the accommodation space and an increase of the salinity associated with the closure of the Sorbas Basin.

\subsubsection{Hueli}

In Hueli, the 10 to $15 \mathrm{~m}$ thick TCC directly overlays the ca. 100-meter-thick Messinian gypsum (Yesares Mb.; Figure 1C). It was subdivided into three ca. 3-4 m thick microbialite beds, with predominant large columns (up to $3 \mathrm{~m}$ high). No evidence for sequence boundaries was found within those deposits, so that the correlation with the northern Sorbas Basin was difficult. Columns displayed alternating stromatolitic and thrombolitic mesofabrics and were locally encrusted and bored by vermetid gastropods. The predominance of MA2 indicated that Hueli was located at a relatively shallow depth. Such a position was rather unusual considering the gypsum substratum and could indicate a tectonic tilting of the southern margin of the Sorbas Basin prior to and/or during TCC deposition. 


\subsection{Agua Amarga Depression}

\section{Las Negras}

The distribution of microbialites was studied at La Molata, a ca. $1 \mathrm{~km}$ long outcrop formed on a volcanic paleorelief. There, the TCC was 15 to $35 \mathrm{~m}$ thick and onlapped the top reef unconformity (Figure 3). Microbialites were present in DS1 to DS4 [27,53]. The base of DS3 and DS4 showed decimeter thick MA1 stromatolites (mostly H2, H3, and B; Figure 13A,E; Table 1) draping ooid grainstone or mixed volcanoclastic-ooid grainstone conglomerates (Figure 13C). These low energy MA1 forms were interpreted as the early transgressive deposits of these sequences. In DS4, they were overlain by MA2b high-energy thrombolite columns and by prograding ooid or pellet grainstones (Figures 5C and 13B,C). Goldstein et al. [53] observed that the thrombolites were thicker and laterally more extensive at lower topographic positions, while cross-bedded ooid grainstones were more developed at high topographic positions. Based on this observation, they interpreted thrombolites as late transgressive deposits and grainstones as highstand and regressive deposits.

\subsection{Bajo Segura Basin}

\subsubsection{Benejuzar}

Benejuzar is located at the periphery of the Bajo Segura Basin depocenter, where a thick gypsum unit accumulated during the Messinian (Figure 1A). There, the ca. $80 \mathrm{~m}$ thick TCC directly overlaid the Messinian gypsum (San Miguel Formation; Figure 3). The first $30 \mathrm{~m}$ of the TCC showed three ca. one meter thick selenite gypsum intercalations, indicating episodes of hypersalinity [47]. Six up to $3 \mathrm{~m}$ thick microbialite beds were found in the basal $50 \mathrm{~m}$ of the TCC, alternating with claystones/marls, cross-bedded oobioclastic and bioclastic grainstones, and vermetid bioherms [46,47]. Microbialites occurred mostly as hemispheroids (H1 to H3; Table 1), either fully laminated or with a thrombolitic core. They almost exclusively belonged to MA1, which indicated low energy conditions at Benejuzar during their deposition.

\subsubsection{Santa Pola}

In Santa Pola, the TCC deposited over a ca. $100 \mathrm{~m}$ thick isolated reef island (surface of ca. $40 \mathrm{~km}^{2}$ ) with a paleo-windward margin characterized by steep reef slopes to the east and south-east (Figure 1B) [40]. We examined a section located on the former protected margin (Meleja) and another one on the exposed margin (Urbanización Panorama section; Figures 1B and 3).

In Meleja, the TCC unit was up to $50 \mathrm{~m}$ thick, but with a variable thickness due to the karstified surface of the underlying reef (TRU), which was locally directly encrusted by microbialites (Figure 3). Decimeter to meter thick tabular beds composed of MA1-type stromatolites (H1 to H3, Co, Cr, W; Figure 6G,H and Figure 7G; Table 1) predominated in Meleja, on the former protected reef margin (Figure 3). These observations indicated that a low energy lagoon protected by the former reef topography covered the western and northwestern part of the region during TCC deposition.

On the former steep reef slopes (Urbanización Panorama), MA1 stromatolites (H2 and H3) developed as transgressive deposits at the base of the TCC, but also at the top of the same unit (Figure 3). Columns (MA2) composed of alternating thrombolitic and stromatolitic mesofabrics were observed within prograding cross-bedded ooid grainstones (Figure 3). The formation of this type of microbialite testified the high energy conditions on the paleowindward margin when the water level was maximum. These deposits were highly deformed and overlaid a ca. $15 \mathrm{~m}$ thick solution-collapse breccia, which indicated the dissolution of underlying gypsum during or after their formation [27]. Overall, the inherited reef topography induced strong contrasts in microbialite fabrics: the paleoleeward margin was dominated by low energy MA1, while both MA1 and high energy MA2 developed on the paleowindward margin. 


\section{Microbialite Mineralogy, Microstructures, and Microfossils}

Dolomite, ranging from calcian $\left(44.35 \mathrm{~mol} \% \mathrm{MgCO}_{3}\right)$ to quasi-stoichiometric $\left(50.52 \mathrm{~mol} \% \mathrm{MgCO}_{3}\right)$, was the most abundant mineral phase (60\% on average; Figure 10 and Table S1) in the majority of the microbialites in this study. In the paragenesis, secondary low magnesian calcite (LMC) cements always preceded. Microfossils and microstructures seemed best preserved when this secondary calcite was present (Figures 15 and 16). Within microbialites, dolomite crystals had various shapes that differed from the secondary, polyhedral dolomite that could be found in some ooid or bioclastic facies [67]. The habits of this dolomite are described and interpreted below (Figures 14-17; Table 2).

\subsection{Peloids}

\subsubsection{Description}

Dolomitic peloids (Table 2) were the most abundant microstructures in TCC microbialites. They could be locally recrystallized in LMC micrite within highly cemented buildups. Peloids were mostly oval or circular with a diffuse boundary and could develop a microsparite rim (Figure 14A,B). They were often grouped or fused (their boundary becoming indistinguishable) to form clusters of different sizes and shapes: rounded, ovoid, and bushy (see Section 7.2). Peloids were predominant in LP and CP microfabrics, and common in LC microfabrics (Figure 4).

\subsubsection{Interpretation}

Peloids are among the most common and typical microbial mineral products in modern $[13,68-70]$ and ancient microbialites [45,62,71], from freshwater to hypersaline environments. In the TCC, peloids were previously interpreted as of microbial origin $[25,30]$. TCC peloids were similar in size and shape to peloids precipitated in modern microbial mats, for instance in some hypersaline lakes of the Bahamas [13], Cuba [16], or the Great Salt Lake [58]. Modern peloids are produced through heterotrophic degradation of extracellular polymeric substances (EPS), leading to the nucleation of micrite (mostly high magnesian calcite) that aggregates and progressively replaces the organic matrix [13,14,72]. The formation of an early microspar rim is common around peloids $[13,73]$ and probably enhances their preservation. Peloids must be differentiated from brine shrimp pellets, which are larger and more regular in shape (Figure 13F).

\subsection{Bushy Peloid Aggregates}

\subsubsection{Description}

Peloids could merge to form predominantly upward or occasionally downward spreading branching networks, typically a few tens to a few hundreds of micrometers wide (Table 2; Figures 9D and $14 C, D)$. Bushy peloid aggregates were commonly found in CP and LP microfabrics. 
Table 2. Composition, size, and distribution of microbial microstructures and microfossils found in TCC microbialites. EPS, extracellular polymeric substances.

\begin{tabular}{|c|c|c|c|}
\hline Type, Dimensions & Mineralogy & Occurrence & Interpretation \\
\hline An:? & Dolomite & $\checkmark \quad$ All type of macrofabrics & $\begin{array}{l}\text { Precipitation on EPS due to degradation by } \\
\text { heterotrophic bacteria }\end{array}$ \\
\hline Bushy peloid aggregates & Dolomite & $\begin{array}{ll}\checkmark & \text { Large to small hemispheroids (H1 to H3) } \\
\checkmark & \text { Stromatolitic (Cr1) and thrombolitic (Cr2) crusts } \\
\checkmark & \text { Wavy laminites (W) } \\
\checkmark & \text { Branches (B) }\end{array}$ & $\begin{array}{l}\text { Precipitation on EPS between filaments within } \\
\text { cyanobacteria dominated mats }\end{array}$ \\
\hline $\begin{array}{l}\text { Filaments (a), } \\
\text { flabellate (b) } \\
\text { and tepees (c) } \\
\text { structures }\end{array}$ & Dolomite & $\begin{array}{ll}\checkmark & \text { (a) Branches (B) } \\
\checkmark & \text { (b) Stacked hemispheroids (SH) } \\
\checkmark & \text { (c) Branches (B) }\end{array}$ & $\begin{array}{l}\text { Precipitation around or within filamentous } \\
\text { cyanobacterial sheaths }\end{array}$ \\
\hline Microspheres & $\begin{array}{l}\text { External wall: } \\
\text { Dolomite } \\
\text { Internal wall: } \\
\text { Mg-Al silicate? }\end{array}$ & $\begin{array}{ll}\checkmark & \text { Large to small hemispheroids (H1 to H3) } \\
\checkmark & \text { Stromatolitic (Cr1) and thrombolitic (Cr2) crusts }\end{array}$ & $\begin{array}{l}\text { Impregnation of coccoid cyanobacteria wall by } \\
\text { (Ca)-Mg-Al silicates in elevated } \mathrm{pH} \text { conditions. } \\
\text { Subsequent reaction between silicates, } \\
\text { metastable (?) carbonates and degraded EPS to } \\
\text { form dolomite (see Figure 20) }\end{array}$ \\
\hline Bean-shaped structures & $\begin{array}{l}\text { Dolomite (rarely } \\
\text { preserved) }\end{array}$ & $\begin{array}{ll}\checkmark & \text { Large to small hemispheroids (H1 to H3) } \\
\checkmark & \text { Stromatolitic crusts (Cr1) }\end{array}$ & $\begin{array}{l}\text { Molds or mineralized cyanobacterial sheaths. } \\
\text { Local enrichments in } \mathrm{Si} \text { imply possible early } \\
\text { silicate nucleation and dissolution }\end{array}$ \\
\hline Microballs and dumbbells & Dolomite & $\checkmark \quad$ Stromatolitic crusts (Cr1) & EPS precipitates \\
\hline $\begin{array}{l}\text { Boring Ooid cortex } \\
\text { front }\end{array}$ & None (porosity) & $\checkmark \quad$ Small hemispheroids (H3) & Boring of trapped grains by endolithic bacteria \\
\hline
\end{tabular}




\subsubsection{Interpretation}

Named microbushes as well [74], bushy peloid aggregates have been generally observed in association with cyanobacteria, in both modern [68,75] and ancient microbialites [71,74], as well as in various environmental settings (fresh, brackish, normal marine, and hypersaline water). In modern sedimentary systems, similar microstructures result from EPS mineralization between filaments in cyanobacteria dominated microbial mats [19,76]. For example, bushy peloidal aggregates have been described in Scytonema/Oscillatoria mats from Shark Bay, Australia, in Schizotrix/Scytonema mats in the modern Andros Island, Bahamas [68], and in Scytonema knobs in San Salvador Island, Bahamas [76]. When mineralized, erected Scytonema filaments may form mineral bridges similar to those observed in peloid-rich lamina, whereas Schizotrix mats tend to form micritic laminae [68].

\subsection{Filaments, Tepee-Like, and Flabellate Structures}

\subsubsection{Description}

Dolomitic peloids could be organized into vertical (Figures 13G and 14F) to oblique "tepee-like" filamentous structures (Figure 14E and Table 2). Such structures were found in stromatolitic branches (Figure 13). Filaments could also form 2-3 mm wide flabellate structures within hemispheroids (Figure 14G and Table 2). Feldmann and McKenzie also described isolated filaments in microbialites from Santa Pola [32].

\subsubsection{Interpretation}

Several works have shown similarities between modern calcified cyanobacteria and filaments found in ancient microbialites $[68,74,77]$. The TCC filaments showed a strong resemblance with modern mineralizing Scytonema sp. filaments from the hypersaline Storrs Lake [76]. Different interpretations have been proposed for the mechanism leading to Scytonema mineralization in modern mats. Some authors postulated that the mineralization occurred around or inside the cyanobacteria sheaths [74,78]. In this model, the photosynthetic uptake of $\mathrm{CO}_{2}$ shifts the carbonate equilibrium toward carbonate ions in the cell microenvironment, which leads to carbonate precipitation if calcium ions are available [79]. Other authors emphasized the role of EPS and heterotrophic activity, notably of certain sulfate reducing bacteria [80], in Scytonema mineralization. They demonstrated that the initial nucleation did not take place in or on the thick cyanobacterial sheaths, but rather within the EPS surrounding the filaments [61,76,81]. Geochemical modelling showed that the impact of cyanobacterial photosynthesis on carbonate precipitation was largely dependent on the amount of dissolved inorganic carbon (including dissolved $\mathrm{CO}_{2}$ ) and $\mathrm{Ca}^{2+}$ availability [82]. Following this model, photosynthetically induced precipitation may be a dominant process in low dissolved inorganic carbon (DIC), high calcium, freshwater to brackish environments, while less of a factor in high DIC marine to hypersaline settings [5]. In these latter environments, cyanobacteria are still playing a key role by structuring the microbial mats and providing organics to fuel heterotrophic activities, responsible for carbonate precipitation [19]. The vertical position of the filaments could be related to: (1) the phototactic behavior of filamentous cyanobacteria $[83,84]$ or (2) seasonal variations in, e.g., turbidity $[68,76,78]$. We found no equivalent of the oblique and tepee structures in modern environments, but their composition and dimension also pointed to a cyanobacterial origin. 

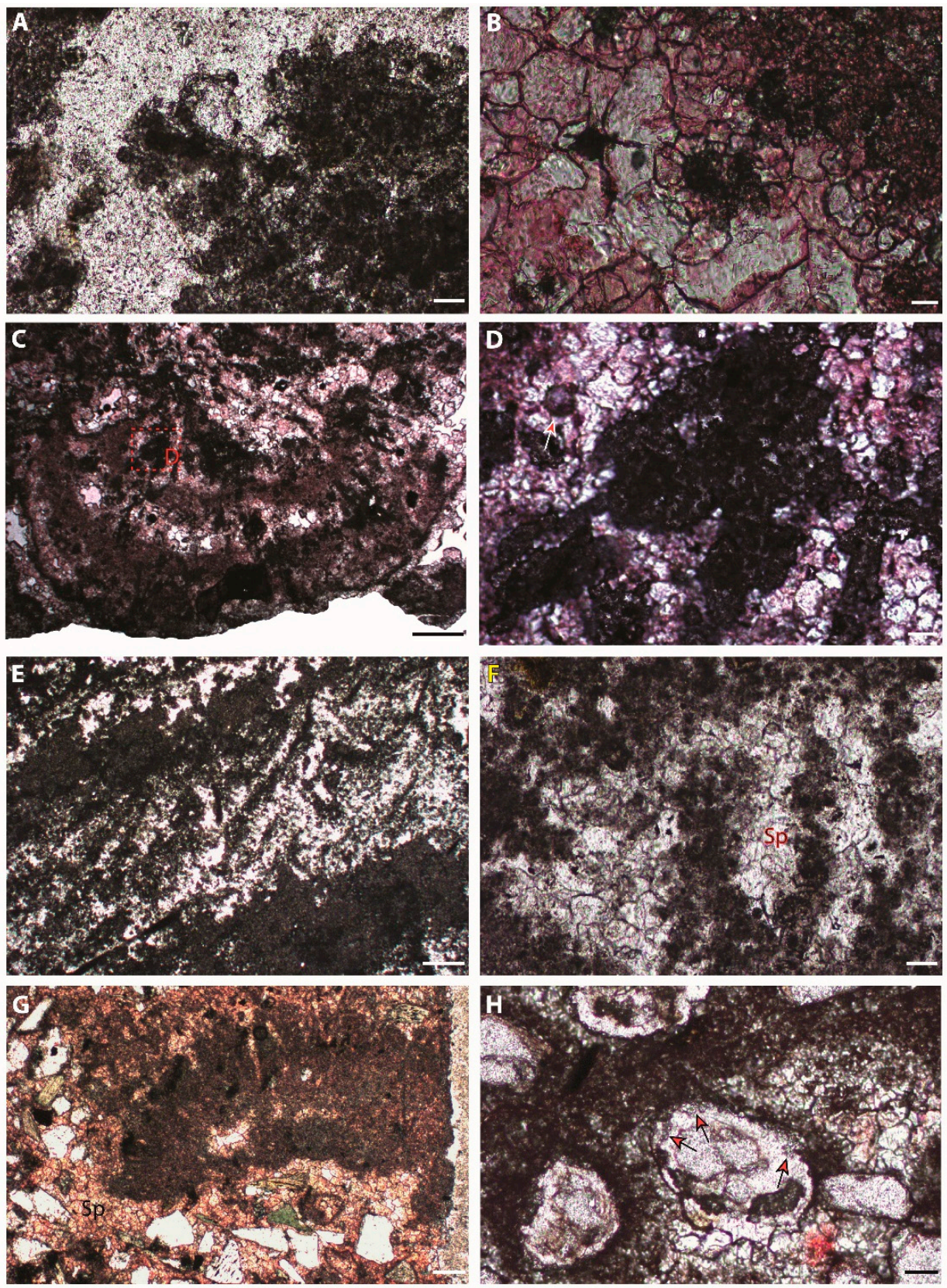

Figure 14. Examples of microbial microstructures found in TCC microbialites (see also Table 2 for a description). All the pictures correspond to polarizing microscope photographs in plane polarized light. (A) Dolomite peloids. Crinkle, Cariatiz, DS2. The scale bar is $50 \mu \mathrm{m}$. (B) Close-up view of peloids encircled by microspar. The scale bar is $20 \mu \mathrm{m}$. (C) Reniform structure including bushy peloid aggregates and diffuse micrite laminae. Thrombolitic crust, Cariatiz, DS4. The scale bar is $500 \mu \mathrm{m}$. (D) Close-up view of (C), showing a downward branching, bushy peloid aggregate. The red arrow indicates a dolomite microsphere. The scale bar is $20 \mu \mathrm{m}$. (E) Tepee peloidal structure. Branch, DS4, Las Negras. The scale bar is $500 \mu \mathrm{m}$. (F) Close-up view of Figure 13G. Peloids are grouped into vertical micro-columns resulting from the mineralization of the sheath of filamentous cyanobacteria. Branch, DS4, Las Negras. The scale bar is $50 \mu \mathrm{m}$. (G) Flabellate structure including some mineralized filaments, probably cyanobacteria. The original micrite was neomorphized into low magnesian calcite. Stacked hemispheroid, Góchar. The scale bar is $200 \mu \mathrm{m}$. (H) Close-up view of a micritic laminae in an ooid-rich microbialite. Ooids (trapped?) are embedded in microbial micrite. Some show a bored rim (red arrows) imprinted in their partly dissolved cortex. These micro-borings could be related to the activity of endolithic bacteria. Small hemispheroid, DS4, Sorbas. The scale bar is $50 \mu \mathrm{m}$. 


\subsection{Microborings}

\subsubsection{Description}

Microbialites with an LC microfabric included locally some microbored grains, mostly ooids, sometimes encased in the edge of a micritic lamina (Table 2; Figure 14H). The borings were less than $20 \mu \mathrm{m}$ deep and a few $\mu \mathrm{m}$ wide and exclusively affected the carbonate part of the grain, the cortex in most cases.

\subsubsection{Interpretation}

Trapped grains, especially ooids, displayed similar borings in modern high energy microbialites. These borings could be compared to those produced by the endolithic coccoid cyanobacteria Solentia, which enhanced the lithification of the microbial buildups by favoring the fusion of grains $[11,85]$.

\subsection{Microspheres}

\subsubsection{Description}

Microspheres (Table 2) were observed in some subtidal hemispheroidal stromatolites (H1; Figures 15 and 16) and in intertidal crusts (Cr1; Figure 17A-E). Some microspheres were single walled, composed of dolomite, and showed micrometer internal expansions (Figure 15G,H and Figure 16). Others were double-walled (Figure 17A-E): (1) the external wall was 10 to $30 \mu \mathrm{m}$ in diameter and 1 to $4 \mu \mathrm{m}$ thick and made of dolomite $(\mathrm{Ca}=\mathrm{Mg})$, with minor $\mathrm{Al}$ and $\mathrm{S}$ content (Figure 17E). Two microspheres could fuse their external walls (Figure 17D); (2) the internal wall was 5 to $7 \mu \mathrm{m}$ in diameter (Figure 17A-E). The internal wall was less than $1 \mu \mathrm{m}$ thick and composed of thin sheets (Figure 17A-E) displaying Mg enrichment (but still with $\mathrm{Ca}>\mathrm{Mg}$ ) and a few percent of $\mathrm{Al}$ and $\mathrm{Si}$ plus minor S (Figure 17E). Thus, the nucleus wall could be made of $\mathrm{Mg}$ carbonates (dolomite?) mixed with altered $\mathrm{Mg}-\mathrm{Al}$ silicates. An alveolar network could be locally observed between microspheres (Figure 17B).

\subsubsection{Interpretation}

In relic microbialites, dolomite microspheres are often interpreted as fossilized coccoids [22]. Feldmann and McKenzie [32] documented comparable structures in the TCC microbialites of Santa Pola and postulated a precipitation of dolomite linked to organic matter decomposition in hypersaline brines. Coccoid organic walls (Aphanocapsa-like) have also been described in Messinian microbialites from cores recovered in the Ionian Basin (DSDP Site 374) [86]. Observations of modern microbial mats and experiments with bacterial cultures showed that similar microspheres could be produced in two similar ways:

(1) Microbially induced precipitation: In situ experiments of precipitation in hypersaline lagoons of Brazil showed that cultures of sulfate reducing bacteria were able to induce the precipitation of extracellular 20-30 $\mu \mathrm{m}$ microspheres made of high magnesian calcite (HMC). These structures were devoid of a nucleus [35].

(2) Fossilization of coccoid cyanobacteria: There is a strong similarity in size and shape between the dolomite microspheres and some coccoid cyanobacteria (e.g., Gloeocapsa sp.) found in abundance in mineralizing microbial mats from Caribbean hypersaline lakes $[7,13,16]$ or the Great Salt Lake [20]. In both cases, coccoid cyanobacteria (as well as occasional filamentous cyanobacteria) can be coated by $\mathrm{Mg}$ silicates. These minerals form in the upper millimeters of the mat, in the zones of active oxygenic and anoxygenic photosynthesis where the $\mathrm{pH}$ locally exceeds 10 [16]. Deeper in the mats, the cells can be subsequently embedded within metastable carbonates, $\mathrm{Mg}$ calcite, or aragonite. Over longer timescales, both metastable carbonates and $\mathrm{Mg}$ silicates that remain for a long period of time (e.g., centuries) in degraded EPS can dissolve and reprecipitate as dolomite [20]. TCC microspheres could result from a similar process, in which the inner wall would represent the initial coating on the coccoid 
cell, and the outer wall could be the result of the reprecipitation of some of the metastable minerals. This could also explain the poor preservation of silicates. The alveolar structure locally preserved between microsphere could be EPS remnants.

\subsection{Bean-Shaped Structures}

\subsubsection{Description}

Structures displaying a bean-shaped section (Table 2 and Figure 17F), represented by molds and better defined structures with a preserved wall, 15 to $20 \mu \mathrm{m}$ long, often occurred in association with microspheres or microballs/dumbbells. When preserved, the wall showed an EDS pattern similar to the microsphere external wall, suggesting that it was made of dolomite. The close periphery of bean-shaped structures showed enrichment in $\mathrm{Al}$ and $\mathrm{Si}$ of a few percent.

\subsubsection{Interpretation}

The bean-shaped structures resembled sections of the sheath of some modern filamentous cyanobacteria [87]. This type of bacteria is often associated with coccoids in cyanobacterial layers of hypersaline lake mats [13]. Thus, we postulated that the association between microspheres and bean-shaped structures was a fossilized coccoid/filamentous cyanobacterial consortium. In modern alkaline and hypersaline lakes, filamentous cyanobacteria sheaths can display a thin $\mathrm{Mg}$ silicate coating $[16,88,89]$. The enrichment in $\mathrm{Al}$ and $\mathrm{Si}$ measured around the bean-shaped structures could be related to the former presence of a similar coating, now dissolved. The scarcity of filaments' wall mineralization compared to coccoids could be indicative of: (1) a more rapid decay of the filament membrane or (2) a lower affinity of the membrane for $\mathrm{Mg}^{2+}$ and/or $\mathrm{Ca}^{2+}$.

\subsection{Microballs and Dumbbells}

\subsubsection{Description}

Dumbbells and microballs (Table 2) were found in one stromatolitic crust (Cr1; Figure 17G). The crystals had various shapes: spherical, oval, rods, dumbbells, or biconcave disks, and ranged from less than $1 \mu \mathrm{m}$ up to $6 \mu \mathrm{m}$ in length and/or diameter. They could be aggregated to from 10 to $20 \mu \mathrm{m}$ wide clusters. A depletion in $\mathrm{Mg}(\mathrm{Mg}<\mathrm{Ca}$ ) was observed compared to surrounding dolomite $(\mathrm{Mg} \approx \mathrm{Ca})$, suggesting a calcian dolomite or high magnesian calcite composition.

\subsubsection{Interpretation}

Dumbbells and rod-shaped crystals made of $\mathrm{Mg}$ calcite are common in modern hypersaline lake microbial mats, from Pacific islands [71,87]. or the Bahamas [14]. Experiments showed that this type of crystal could nucleate on EPS of sulfate reducing bacteria cultures $[35,80]$. 

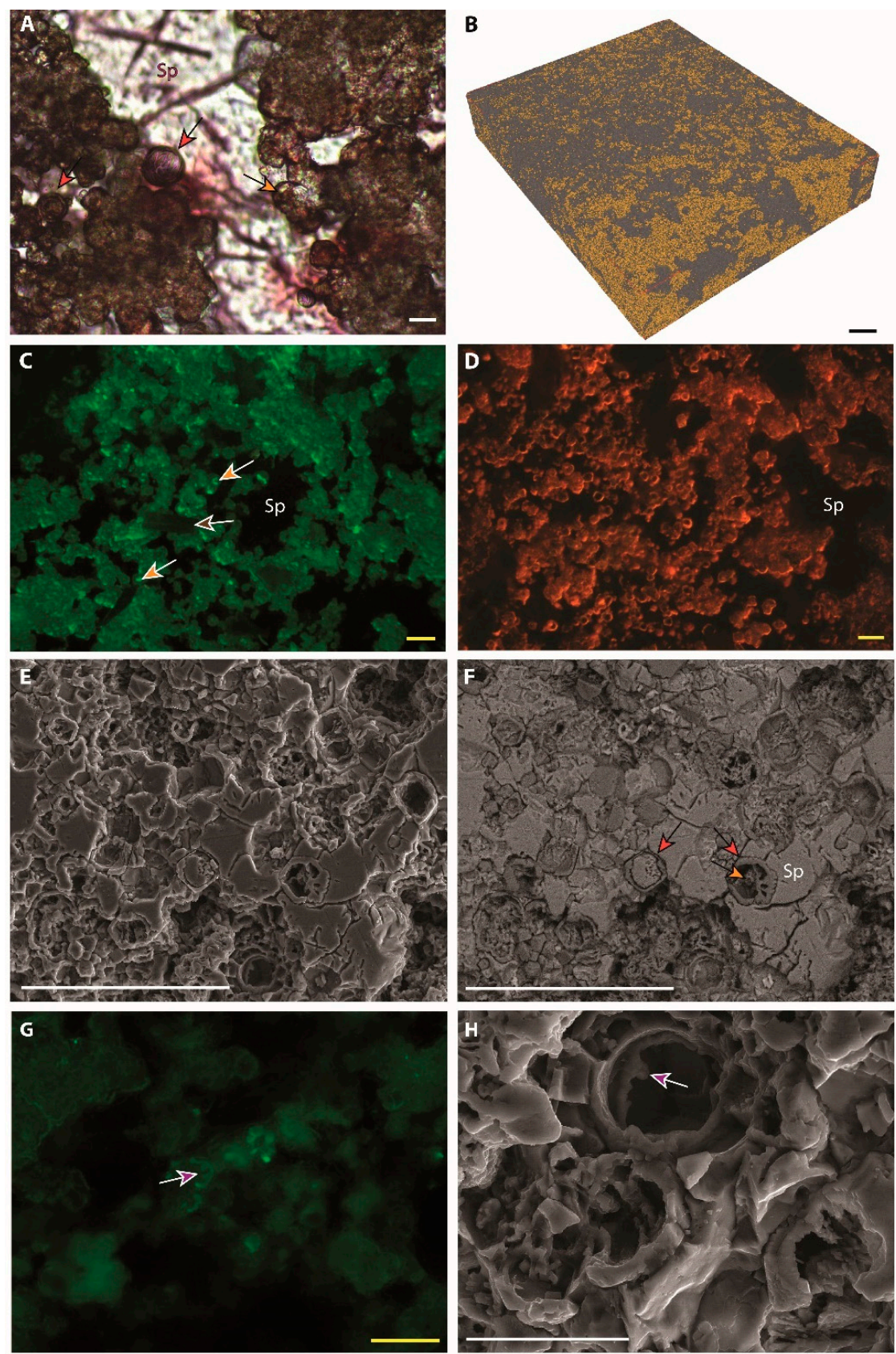

Figure 15. Microstructures (Table 2) of a large stromatolite hemispheroid sampled in the bed of Figure 6B. Sorbas, DS3. (A) is a plane polarized light image; $(\mathbf{B})$ is a 3D CT scan reconstruction; $(\mathbf{C}, \mathbf{G})$ are reflected light fluorescence images; (D) is a cathodoluminescence image; (E,F,H) are SEM images, in secondary electron mode for $(\mathbf{E}, \mathbf{H})$ and back-scattered electron mode for (F). (A) The clusters are composed of brown dolomite microspheres, 10 to $20 \mu \mathrm{m}$ in diameter (red arrow), some with a nucleus (orange arrow). The scale bar is $20 \mu \mathrm{m}$. (B) 3D internal fabric of the stromatolite. Primary dolomite (light orange) is organized in hundreds of micrometer clusters of microspheres and peloids, with secondary calcite spar developing in between (gray). The pixel size is $1 \mu \mathrm{m}$; the scale bar is $100 \mu \mathrm{m}$. (C) The microspheres show a green fluorescence with a locally bright nucleus (orange arrow), contrary to the spar cement (Sp) and the siliciclastic particles (mica; brown arrow). The scale bar is $50 \mu \mathrm{m}$. (D) They have also an orange color in cathodoluminescence. The scale bar is $50 \mu \mathrm{m}$. In (E,F), the microspheres have an external wall (red arrows) and sometimes a complex nucleus (orange arrow). The scale bar is $90 \mu \mathrm{m}$. $(\mathbf{G}, \mathbf{H})$ show internal expansions on the dolomite wall of a sphere (purple arrow). The scale bars are respectively $40 \mu \mathrm{m}$ and $20 \mu \mathrm{m}$. 
A

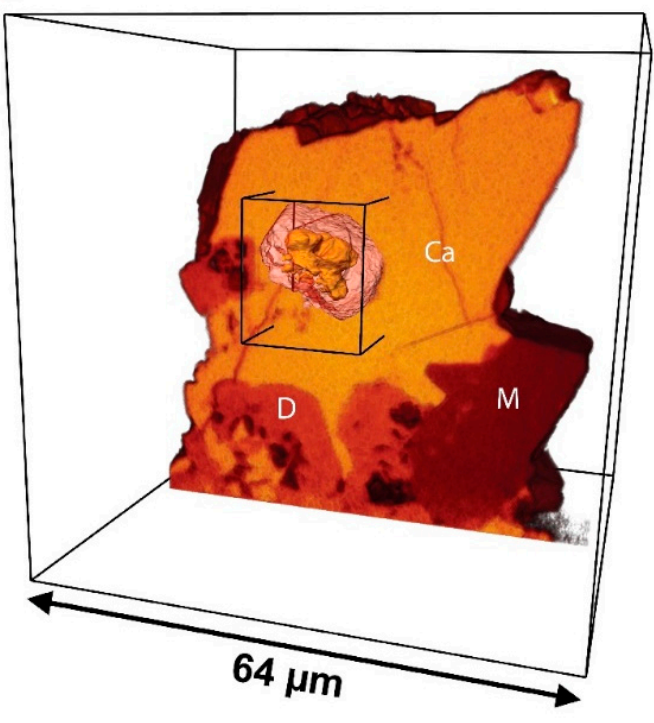

B

[um]

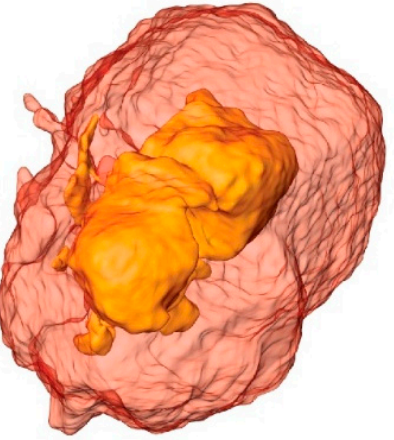

C
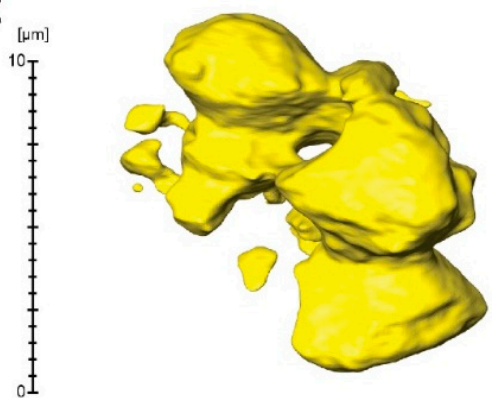

Figure 16. 3D renderings of the nanotomographic reconstruction of a fragment from the same sample as Figure 15. (A) Dolomite microspheres (D) and detrital mica (M) are encased in calcite microspar cement (Ca); (B) 3D rendering of a single microsphere. The red envelope is made of dolomite. The yellow volume is the internal porosity of the microsphere. (C) Isolation of the internal porosity of the microsphere visualized in (B).
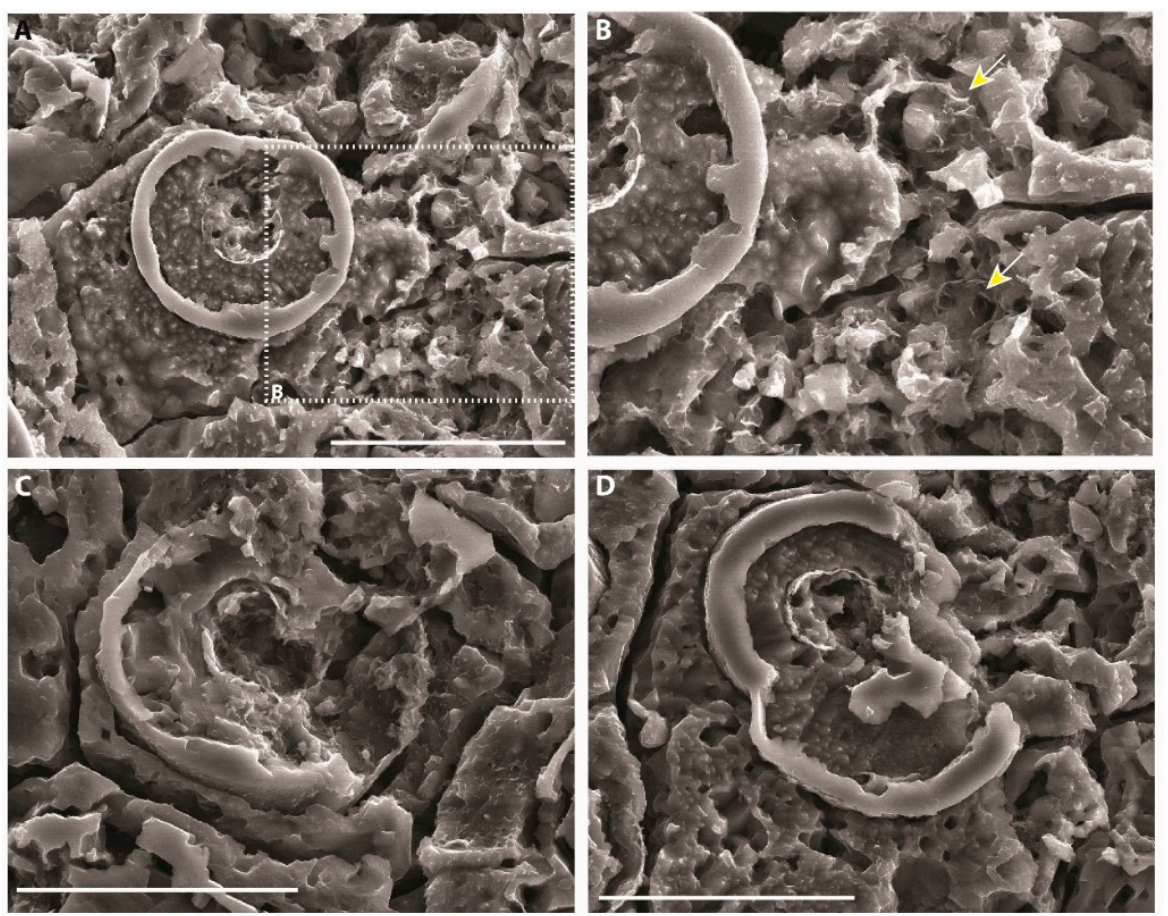

Figure 17. Cont. 

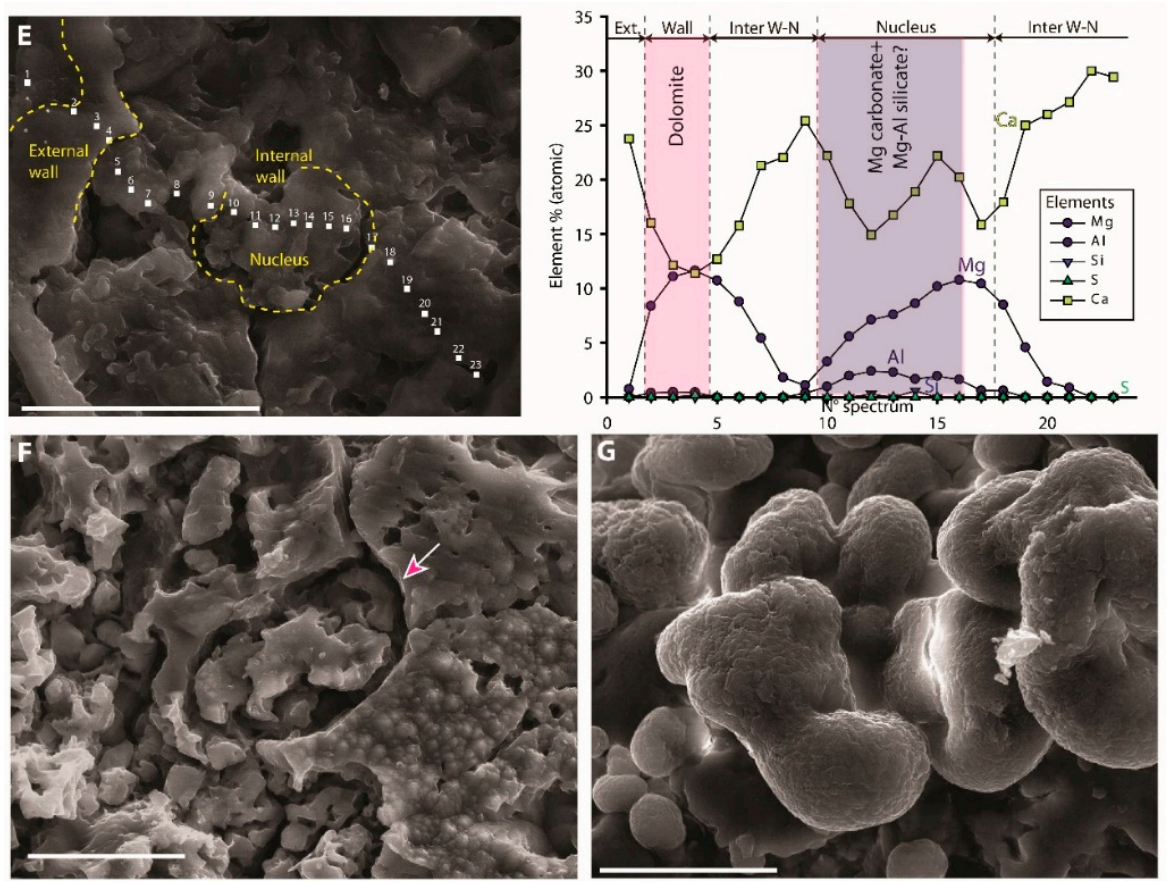

Figure 17. Selected microbial microstructures (Table 2) observed under SEM (secondary electron mode). In (A-D), the detail of isolated ((A-C)) or double ((D)) microspheres, interpreted as fossilized coccoid cells. The outer wall is composed of dolomite, while the inner wall shows enrichment in $\mathrm{Mg}, \mathrm{Al}$, and $\mathrm{Si}$ that are interpreted as remnants of $\mathrm{Mg}-\mathrm{Al}$ silicates. The alveolar structure surrounding cells ((B); yellow arrow) could correspond to former exopolymeric substances (EPS). The scale bars are $20 \mu \mathrm{m}$. (E) To the left, the position of an EDS transects a microsphere (same sample as (A-D)). The scale bar is $7 \mu \mathrm{m}$. To the right, the evolution of $\mathrm{Mg}, \mathrm{Al}, \mathrm{Si}, \mathrm{S}$, and Ca content along this transect. The microspheres have two walls. The external wall is massive with internal expansions and is composed of dolomite. The internal wall is thinner, less regular (see (A-D)), and delineates a nucleus enriched in $\mathrm{Al}$, Si, and S, possibly related to the presence of $\mathrm{Mg}$-Al silicate remnants mixed with $\mathrm{Mg}$ carbonates. (F) Bean-shaped structure (pink arrow), interpreted as the mold of a former filamentous cyanobacteria sheath (Table 2). Stromatolitic crust (Cr1; Table 1), Cariatiz, DS4. The scale bar is $10 \mu \mathrm{m}$. (G) Dolomite microballs and dumbbells. The scale bar is $10 \mu \mathrm{m}$. Stromatolitic crust (Cr1; Table 1), Cariatiz, DS4. The scale bar is $40 \mu \mathrm{m}$.

\section{Discussion}

\subsection{Salinity and Sedimentary Dynamics Controls on Microbialite Associations: Comparison with Modern Counterparts}

Low energy microbial mats similar to MA1 (Figures 5A, 6 and 7) form a continuous to sub-continuous layer covering the bottom of Caribbean hypersaline (salinity ca. 50-100\%, up to $200 \%$ o) and slightly alkaline (pH 8.5-9.5) lakes (e.g., Storrs Lake, Salt Pan, and Big Pond in the Bahamas, Cayo Coco Lagoonal Network in Cuba; Figures 18 and 19) [13-16]. These shallow lakes, less than $2 \mathrm{~m}$ deep, are protected from oceanic waves by coastal barriers (e.g., beaches, fossil reefs, or eolianites; Figure 18C2), although they can be affected by strong waves during tropical storms. Major storm surges create waves that can transport carbonate sand grains, which can be subsequently trapped and bound in stromatolites. Microbial mats preferentially lithify at the lake margin and pass to soft mats at the center of the lake [13-15]. Due to increasing accommodation space and/or light availability [90], the mats increase in thickness from shallow to deep areas. They exhibit various macrofabrics: small to medium hemispheroids (Figure 18D) or knobs (Figure 18B) with a rounded (Figure 18A) "snake-like" or cerebroid (Figure 18C1) surficial morphology develop at the lake border, while planar mats, large hemispheroids, and isolated heads cover the deepest parts of the lake [13-15,91]. 
Laminated mats progressively mineralizing to form stromatolites are dominant in most lakes [15,16]. A similar predominance of stromatolites characterized TCC's MA1 (Figure 5A). Thrombolite crusts can be locally abundant (e.g., in Salt Pan and Storrs Lake) and alternate with laminated crusts (Figure 18E). Alternating laminated and clotted mesofabrics could result from differences in dominant microbial communities [32,92] or from seasonal fluctuating water depth and turbidity in the lake (e.g., in Storrs Lake) $[75,91,93]$. Computer simulations of microbialite growth indicated that stromatolite-thrombolite alternation can be achieved by varying the way microbial communities obtain their main sources of energy and nutrients [93]. Following these simulations, shallow and/or clear water would induce a "light-driven" organization of microbial communities in layers along a light/geochemical gradient that would induce laminated mesofabrics (solar radiation being the main source of energy). Contrastingly, increasing turbidity or water depth would reduce light control on microbialite growth, trigger a change from phototrophic to chemotrophic dominated communities, and thus, favor clotted mesofabrics (redox reactions being the dominant source of energy). At the micro-scale, microbial activity induces the precipitation of high magnesian calcite (HMC) in the form of peloids nucleating in the exopolymeric substances (EPS; Figure 19B), similar to the dolomite peloids found in TCC microbialites (Figure 14A,B). Some laminated mats are dominated by coccoid cyanobacteria (e.g., Gloeocapsa sp. in Salt Pan; Figure 19E-G) [13,16], showing a striking resemblance to TCC microspheres (Figures 15, 16 and 17A-E). Similarly, the sheath of the vertical filamentous cyanobacteria (e.g., Scytonema sp.) permineralizing inside Storr's lake knobs (Figure 19C) [76] are comparable to the filaments found in stromatolitic branches from Las Negras (Figures 13G and 14F). These observations indicate that cyanobacteria communities were similar, at least in terms of morphology, in TCC's MA1 and in the modern Caribbean seawater-fed hypersaline lakes.
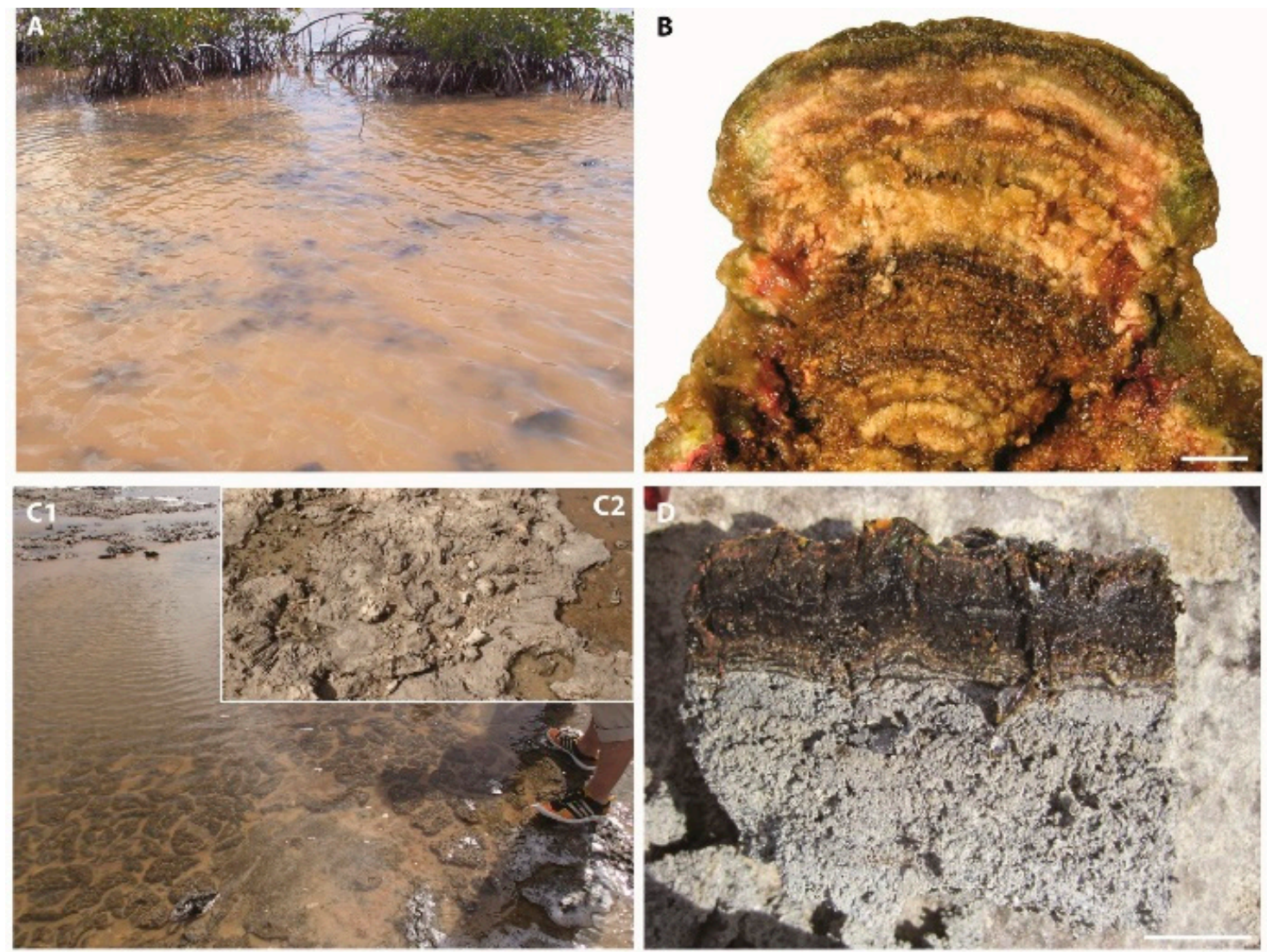

Figure 18. Cont. 

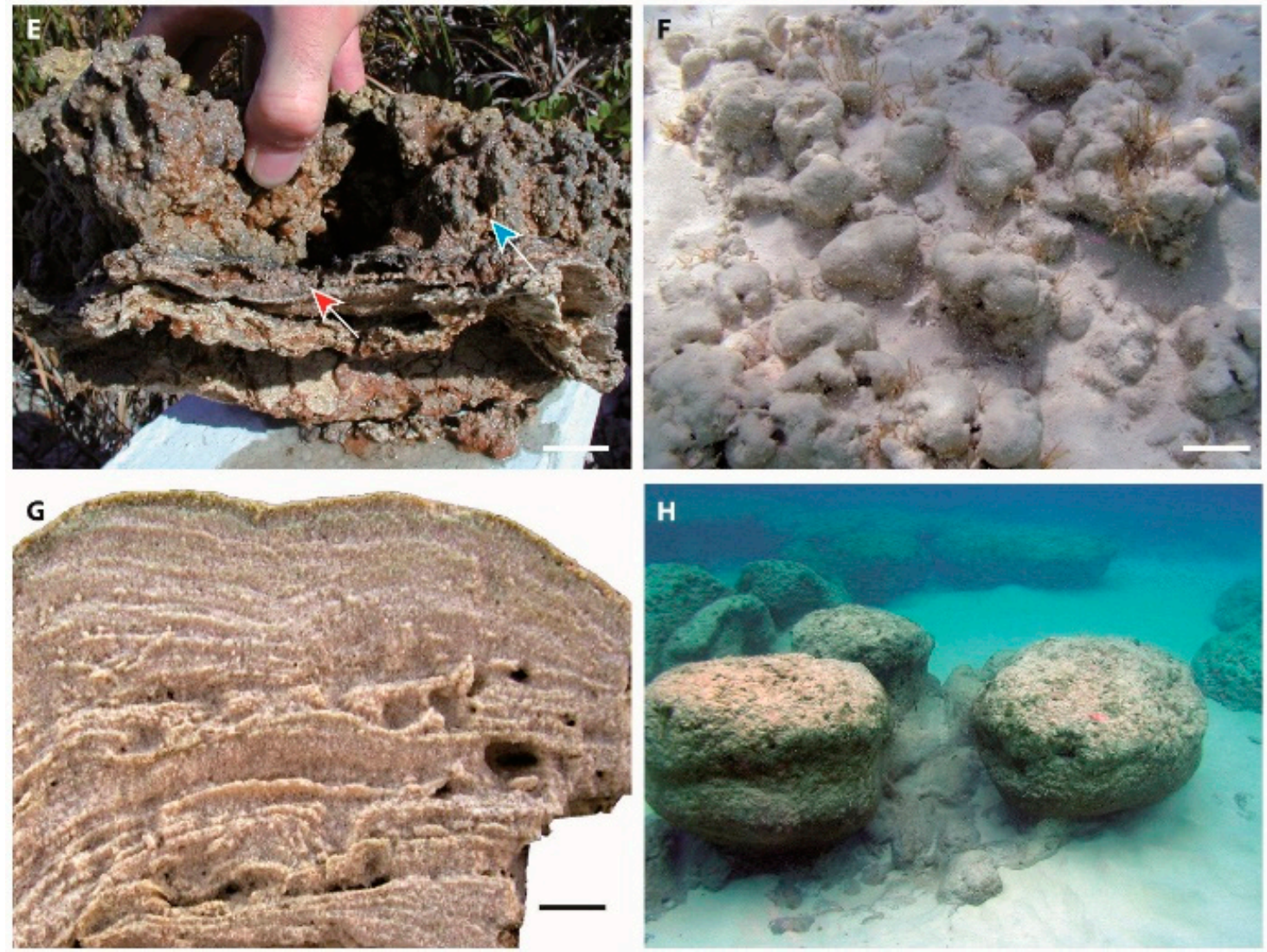

Figure 18. Macro- and meso-fabrics of modern microbialites from hypersaline lake and open marine environments, Bahamas and Cuba. (A) Patches of Scytonema knobs/hemispheroids in shallow and highly turbid hypersaline waters (Storr's Lake, San Salvador Island). (B) Cross-section Scytonema-rich hemispheroid to knobby stromatolite (see A), showing fine lamination composed of high magnesian calcite (Storr's Lake, San Salvador Island). The scale bar is $1 \mathrm{~cm}$. (C1) Lithifying hemispheroid mat covering the bottom of the low energy hypersaline lagoon of Santa Lucia, northern Cuba. The lagoon developed over a Pleistocene coral reef, with mats encrusting dead corals (C2). (D) Cross-section through a lithifying hemispheroid to crinkle microbial mat from Santa Lucia lagoons (Cuba; see C1). The top of the mat shows a green lamina corresponding to the oxygenic photosynthesis zone dominated by cyanobacteria. It overlies a red lamina rich in purple sulfur bacteria performing anoxygenic photosynthesis. Below, white microbially-induced carbonate precipitates (high magnesian calcite mostly) plus "trapped and bound" particles from storm deposits contrast with dark (organic-rich) laminae. A light grey bioclastic mud is visible below the mat. The scale bar is $2 \mathrm{~cm}$. (E) Section through a large microbialite crust developing in the deeper (northern) part of Storr's Lake (San Salvador Island). The sample shows an alternation of stromatolitic (red arrow) and thrombolitic (blue arrow) mesofabrics that could be related to seasonal changes in water depth and the associated increase in turbidity, which are common in this hypersaline lake. The scale bar is $2 \mathrm{~cm}$. (F) Small stromatolitic branches developing on the normal marine, high energy beach of Highborne Cay. The scale bar is $5 \mathrm{~cm}$. (G) Cross-section through a small stromatolitic column from Highborne Cay (Bahamas) that shows well-developed lamination. The stromatolite is mainly composed of "trapped and bound" particles (ooids and bioclasts). The lamination is produced by the iterative development and rapid lithification through aragonite production of a very thin biofilm that is forming at the top of the sedimentary buildup. The scale bar is $1 \mathrm{~cm}$. (H) Large stromatolitic and thrombolitic columns developing in the shallow, sub-tidal environment of Darby Island. The large heads are often organized in ridges or patches visible in the back of the picture. These microbialitic heads are living in open sea conditions and are often perforated by sponges or bivalves, as well as encrusted by green algae (e.g., Batophora), bryozoans, or corals (e.g., Siderastrea radians). 
Open-marine microbialites developing in the shallow water in the Exumas, Bahamas (salinity of ca. $35 \%$; moderate alkalinity, $\mathrm{pH}$ ca. 8), are exposed to a strong and permanent hydrodynamic regime due to waves and tidal currents $[10,11,94,95]$. Individual buildups or groups of heads and columns (Figure 18G,H), branches (Figure 18F), crusts (Figure 19A), or ridges are actively growing above ooid sand from the intertidal zone up to ca. $10 \mathrm{~m}$ deep. The morphology of the Exumas microbialites and the composition and dynamics of associated sediments are similar to MA2a (Figure 11A-F). Low relief ridges develop in low accommodation areas with frequent, but shorter periods of burial by sands, while several meter high columns are characteristic of a higher water level with rare, but longer periods of burial $[57,96]$. The predominant vertical accretion in high energy microbialites has been interpreted as a way to prevent long-term sand burial $[57,93]$. Open marine microbialites display a well- to poorly-defined lamination, depending on the intensity of the disruption caused by the organisms colonizing these hard substrates [59,60,97]: infauna (e.g., naked reticulopods, worms, crustaceans, mollusks) including borers (e.g., bivalves and sponges), epifauna including encrusters (red algae, corals, bryozoans; Figure 19A), or dwellers (green and brown algae; Figure 18F). The scarcity and poor preservation of lamination in some MA2a microbialites (Figure $11 \mathrm{~A}-\mathrm{C}$ ) could be related to the development of comparable groups of encrusters and borers [25], some being preserved (bivalves, vermetids, red algae; Figure 11D-H). The mineralization of open marine Bahamian microbialites occurs in a three-step microbial community cycling, dependent on seasonal (temperature, light fluctuations, etc.) and stochastic events such as hurricanes [11,12,95,96]: (a) filamentous cyanobacteria mats, dominated by Schizotrix sp., trap and bind grains; (b) biofilms rich in heterotrophs (e.g., sulfate reducers) degrade EPS, leading to the release of $\mathrm{Ca}^{2+}$ and subsequent precipitation of aragonitic micrite laminae; and (c) mats dominated by the endolithic cyanobacterium Solentia sp., which bores and fuses trapped grains, strengthening the buildup. Evidence for those three steps was preserved in TCC microbialites (e.g., Figure 14H).

Kolodka et al. [98] tested the influence of sedimentary dynamics on TCC microbialite development in the Sorbas Basin. This was achieved by reproducing the field-observed microbialite architecture in numeric stratigraphic simulations. Best-fit simulations were obtained with growth rates of $0.27 \mathrm{~m} \cdot \mathrm{ky}^{-1}$ and $0.46 \mathrm{~m} \cdot \mathrm{ky}^{-1}$ for MA1 and MA2a, respectively. Those values corresponded to average growth rates measured on low and high energy Holocene microbialites (see the detailed references in Kolodka et al. [98]). In sum, slow-growing MA1-type forms dominate low energy shallow water lakes/lagoon, while fast-growing MA2a-type microbialites will develop in high energy zones exposed to waves. With the sea level rising in the coming centuries, the protected Caribbean lakes and lagoons located a few meters above sea level could be flooded and exposed to open marine conditions. This flooding could result in the formation of a similar stratigraphic pattern as observed for example in Góchar, i.e., MA2a-type above MA1-type microbialites (Figure 12C-E).

The giant columns of MA2b (Figures $5 \mathrm{C}$ and $13 \mathrm{~A}-\mathrm{C}$ ) seem to have no modern counterparts in the Caribbean region, both in terms of buildup size and internal fabrics. This could be due to Caribbean hypersaline lakes/lagoons being protected from permanent waves by hydrodynamic barriers (e.g., coastal dunes) and also to insufficient accommodation space. Though purely continental and as such different from the seawater influenced TCC deposits, the Great Salt Lake (GSL; UT, USA) is both hypersaline and has quasi-permanent wind waves [99]. Giant columns (up to $8 \mathrm{~m}$ in height) [100] have developed within ooid and Artemia fecal pellet sands since the beginning of the Great Salt Lake phase, ca. $11.5 \mathrm{Ky}$ ago $[58,101,102]$. The microbial mats forming these buildups trapped large quantities of ooids and pellets, forming grain-rich microbialites $[58,102,103]$ similar to MA2b (Figure 13). Thus, we postulated that MA2b developed in a high energy and hypersaline environment during the restriction of the Agua Amarga depression (Figure 5C). 


\subsection{Long-Term Controls on Microbialites Distribution: Water Level, Substratum, and Evaporite Deformation/Dissolution}

TCC platforms deposited on two types of substrate: (i) fossil coral reefs of the Reef Unit that formed stable topographic highs exposed to waves and tidal currents; (ii) gypsum deposited from the basin depocenters to the toe of the reef paleoslopes (Figure 3) [30]. Dissolution and deformation of the gypsum occurred synchronously with TCC deposition in most of the studied localities. The deformation was more intense on the reef paleoslopes, e.g., Cariatiz or the paleowindward margin of the Santa Pola reef (Figure 3) [27]. Gypsum never covered the upper parts of reef slopes or reef flats, so that in these areas, TCC deposition was mostly controlled by water level variations and not influenced by accommodation changes related to gypsum deformation/dissolution [30]. In Las Negras, the thin continuous stromatolite beds (MA1) observed at the base of depositional sequences (Figures 3 and 13A,C,E) were interpreted as early transgressive deposits [53]. Later, during the transgression, and possibly during the water level highstand, increasing accommodation space and exposure to waves could have led to the formation of columnar thrombolites (MA2; Figures 5C and 13A-C). At the same time, oobioclastic and pellet sands were deposited in shallower water, in the upper shoreface, and in the foreshore. Finally, oobioclastic deposits could have prograded over thrombolites during the regressive part of depositional sequences, forming so-called build and fill sequences [50]. A similar pattern of low energy microbialites (MA1) grading upward into high energy forms (MA2a) was documented on the northern margin of the Sorbas Basin, e.g., in Góchar's DS3 (Figure 12) and in Cariatiz's DS2 and DS3 (Figure 3) [27]. In these localities, alluvial fan conglomerates recorded the regressive part of the depositional sequence (Figures 3 and 12). A thick (up to $5 \mathrm{~m}$ ) and continuous MA1 bed also formed during the transgressive part of DS3 in Sorbas (Figures 3 and 6A,B). However, the ooid clinoforms prograding over this bed were devoid of microbialites, while showing abundant deformation related to fluid expulsion and indicative of sediment instability (Figure 3).

Overall, MA2 mostly developed over former upper reef slopes and reef flats. This could be explained by the combination of (i) a stable and rigid substratum (modern Bahamian stromatolites and thrombolites develop exclusively on stable substrates (e.g., hardgrounds and firmgrounds), while being unable to colonize mobile sands [104]); (ii) hydrodynamic requirements, i.e., permanent wave energy, supporting the development of MA2 microbialites. Numerical modelling showed that the flooding of steep fore reef slopes and smooth reef flats induced strong wave runups [105]. Overall, a water level driven alternance between low energy (MA1) and high energy (MA2) microbialites was better expressed where the TCC developed over wide, flat, and stable reefal substrata. The exposure to wind waves plays a major role in the distribution of modern Caribbean stromatolites. Microbialites similar to MA2a (Figure 18F-H) are mostly found in the back reef area of the windward margin of the Exuma Cays [33,57], while MA1-like microbialites (Figure 18A-E) are abundant in protected lakes, lagoons, and mudflats [13-15,106]. In Santa Pola, MA1 predominates on the former protected margin of the reef, while being relatively rare and coexisting with MA2 on the paleowindward margin (Figure 3). The configuration of the inherited reef substratum (windward vs. leeward) [40] likely played a major role in the microbial distribution.

In most of the studied localities, syn-sedimentary deformation features (e.g., platform flexure, growth faults inducing overthickening of microbialite beds, antiforms, and folds) indicated that the movement and dissolution of the gypsum substratum initiated during DS3 (Figure 3) [27]. The deformation was particularly intense on the northern margin of the Sorbas Basin (Góchar, Moras, Cariatiz), where an angular unconformity recorded a tilting of DS1 or both DS1 and DS2 below DS3 and DS4 (Góchar; Figure 12). Gypsum dissolution could have increased surface water salinity through sulfate-rich brine seepage (Figure 2B), thereby excluding most of the grazers (e.g., gastropods) [15,107]. The combination of a third order sea level drop leading to basin restriction and hypersalinity could explain the colonization of the TCC platforms by microbialites during DS4 (Figure 3). 

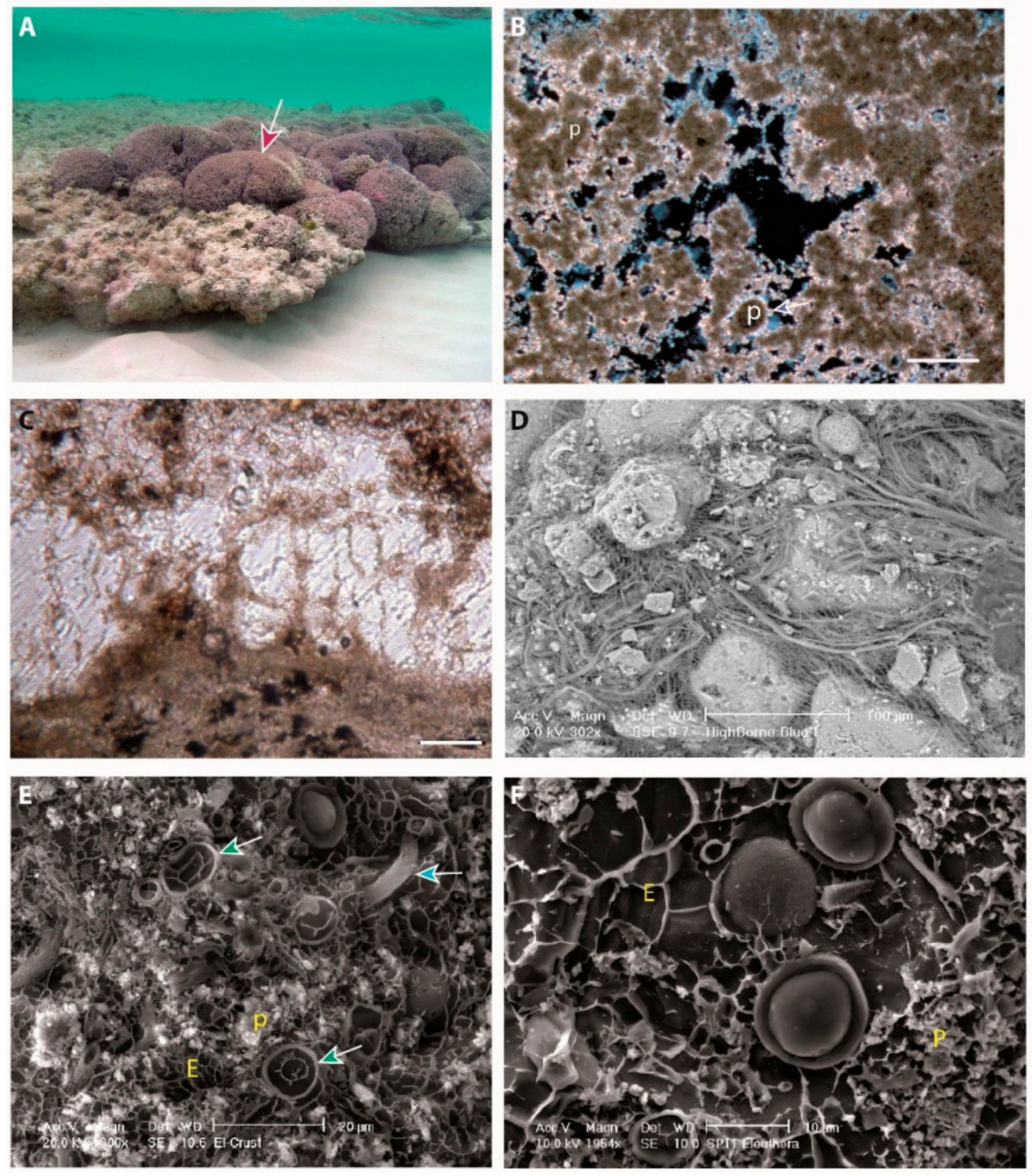

Figure 19. Cont. 

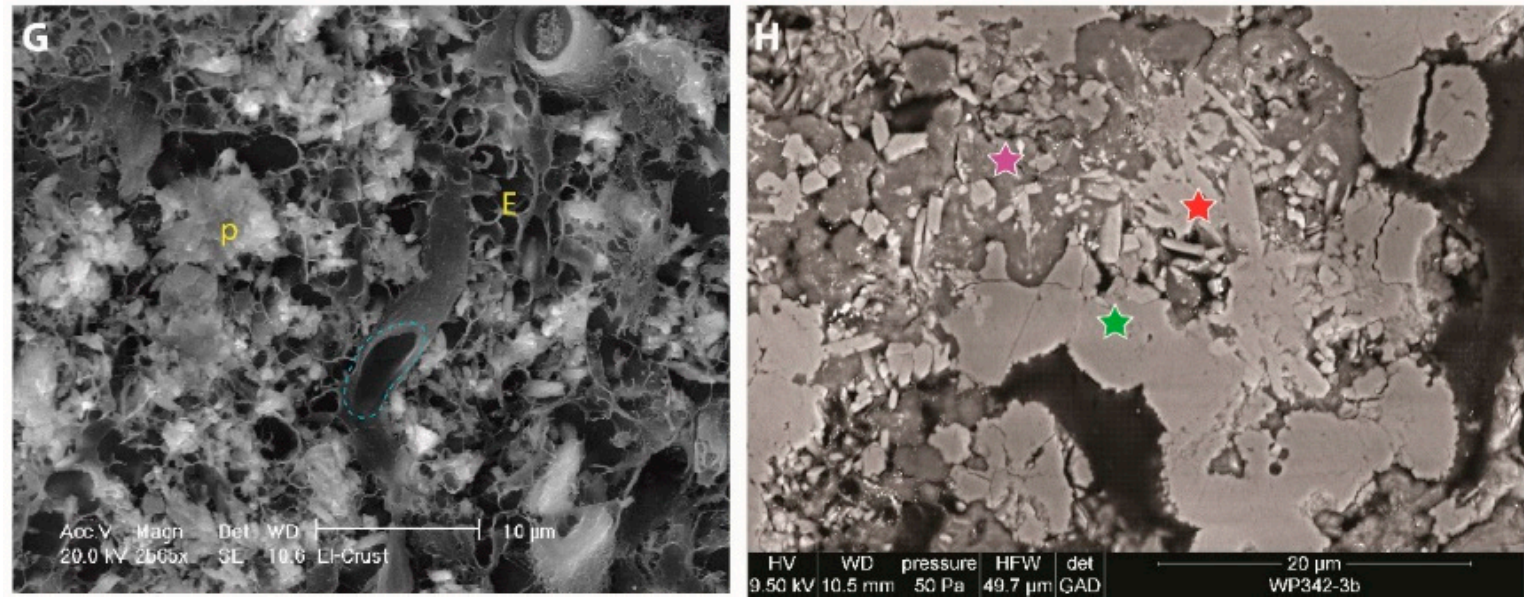

Figure 19. Macrofabrics, microfabrics, and microstructures of modern microbialites from the Bahamas and the Great Salt Lake (USA). (B,C) are thin section photomicrographs. (D-G) have been taken with an FEG-ESEM equipped with a cryotransfer unit. $(\mathbf{H})$ has been taken with an FEG-SEM. (A) Thrombolitic crust growing in high energy oobioclastic sands, encrusted by red algal bushes (purple arrow) on Highborne Cay beach (Bahamas). (B) Peloids (p) precipitated in the stromatolites of Big Pond Lake (Figure 18C,D) and rimmed by a microspar fringe (blue arrow). The scale bar is $100 \mu \mathrm{m}$. Polarized light. (C) Alternating vertical and horizontal calcified filaments of Scytonema (Storrs Lake, Bahamas). The scale bar is $100 \mu \mathrm{m}$. Plane polarized light. (D) Ooids trapped and bound by vertically oriented Schizotrix filaments in open marine stromatolites of Highborne Cay (see also Figure 18H). (E) Coccoid (Gloeocapsa sp. and/or Entophysalis sp.; green arrow) and filamentous (Phormidium sp. and/or Microcoleus sp.; blue arrow) cyanobacteria embedded in a lithifying EPS matrix (E), showing a typical alveolar (tectic) structure. Note that the precipitation is initiated within the EPS matrix and not on the bacteria itself. Peloids (p) are made of high magnesian calcite. Salt Pan, Eleuthera, Bahamas. (F) Same sample as (E), with a close up view of coccoid cyanobacteria. (Salt Pan, Eleuthera Island). (G) Same as (E), but this part of the mat is dominated by filamentous cyanobacteria. The cyanobacteria section (highlighted in blue dots) strongly resembles the bean-like structures of Figure 11D. (H) Image of a Holocene thrombolite from the Great Salt Lake (UT, USA). Magnesian silicates form dark-grey globules (purple star) associated with "rice-grain" aragonite crystals (red star). A reaction between these two metastables minerals and degraded EPS could result in the formation of the surrounding dolomite globules (green star).

\subsection{Microbial and Diagenetic Influence on Microfabrics and Mineral Precipitation}

A geomicrobiological model illustrating the formation of TCC microbialites at various stages of diagenesis is proposed in Figure 20. This model proposes microbial and diagenetic pathways that could have resulted in the formation of some key microbialite features: (i) the laminated peloidal microfabric (Figures 4 and 9B,C,F) (this microfabric is widespread in modern $[14,16,58,77]$, as well as in ancient microbialites $[65,108,109]$ ); (ii) dolomite microspheres that likely represent fossilized coccoid cyanobacteria (see Section 7.5). This community has a fundamental influence on mineral precipitation and microfabrics in microbialites [13,20,22]. In Caribbean hypersaline lakes (Figures 18 and 19), the "classical model" of stromatolite formation involves a layered distribution of different types of microbial communities along a light/geochemical gradient inside the microbial mat [12,16,110]. At the top, cyanobacteria produce EPS and increase the alkalinity through oxygenic photosynthesis during daytime [7]. Deeper in the mat, the rapid consumption of free oxygen through aerobic respiration (using $\mathrm{O}_{2}$ as an electron acceptor) leads to the formation of an anoxic environment, in which anaerobic metabolisms are then responsible for the oxidation of the remaining organic matter using other terminal electron acceptors for respiration (e.g., $\mathrm{SO}_{4}{ }^{2-}, \mathrm{NO}^{3-}, \mathrm{Fe}^{3+}$ ). This view has strongly evolved in the last few decades due to the fact that sulfate-reducing bacteria (SRB) have been proven to be very active at the top of the mat, in the photosynthetically active, oxic zone (see [111] for a review). 
The majority of microbial metabolisms (including SRB) display the highest rates in the uppermost few millimeters of microbial mats, where most of the nutrients and labile forms of carbon can be found and efficiently recycled. Because sulfate is abundant in marine and hypersaline water, SRB often play an important role in microbialite formation because of their ability to increase carbonate alkalinity and to remove sulfate [80], which inhibits carbonate precipitation [19,34,112]. As SRB activity is photo-independent, it potentially favors carbonate precipitation during both day and night, while other bacterial metabolisms, such as aerobic respiration, rather enhance carbonate dissolution $[7,12,19,110]$. Hotspots of sulphate reduction are often superposed with high magnesian calcite (HMC) peloids. The degradation of the organic matrix by SRB could release the $\mathrm{Ca}^{2+}$ ions bound to the EPS, allowing carbonate precipitation [13]. Pace et al. [16] also showed the importance of anoxygenic phototrophs, in that case purple sulfur bacteria (PSB), in the initiation and formation of a high magnesian calcite (HMC) lamina in Cuban hypersaline microbialites. This lamina formed very quickly (less than 18 months) at the interface of oxygenic and anoxygenic photosynthesis zones, where major changes in porewater and EPS composition occurred. The $\mathrm{pH}$ reached its maximum $(>10)$ at this interface, allowing for the nucleation of HMC. The elevated SRB activity developing just below this interface suggested a synergy between PSB, oxidizing sulfides, and SRB, reducing sulfates. These observations indicated a strong contribution of the bacteria associated with the sulfur cycle to the formation of the carbonate lamina [12,112]. A similar mechanism could have led to the formation of the laminated pattern in some TCC stromatolites, with carbonate laminae recording the position of successive oxygenic-anoxygenic photosynthesis interfaces over time (Figure 20; Step 1).

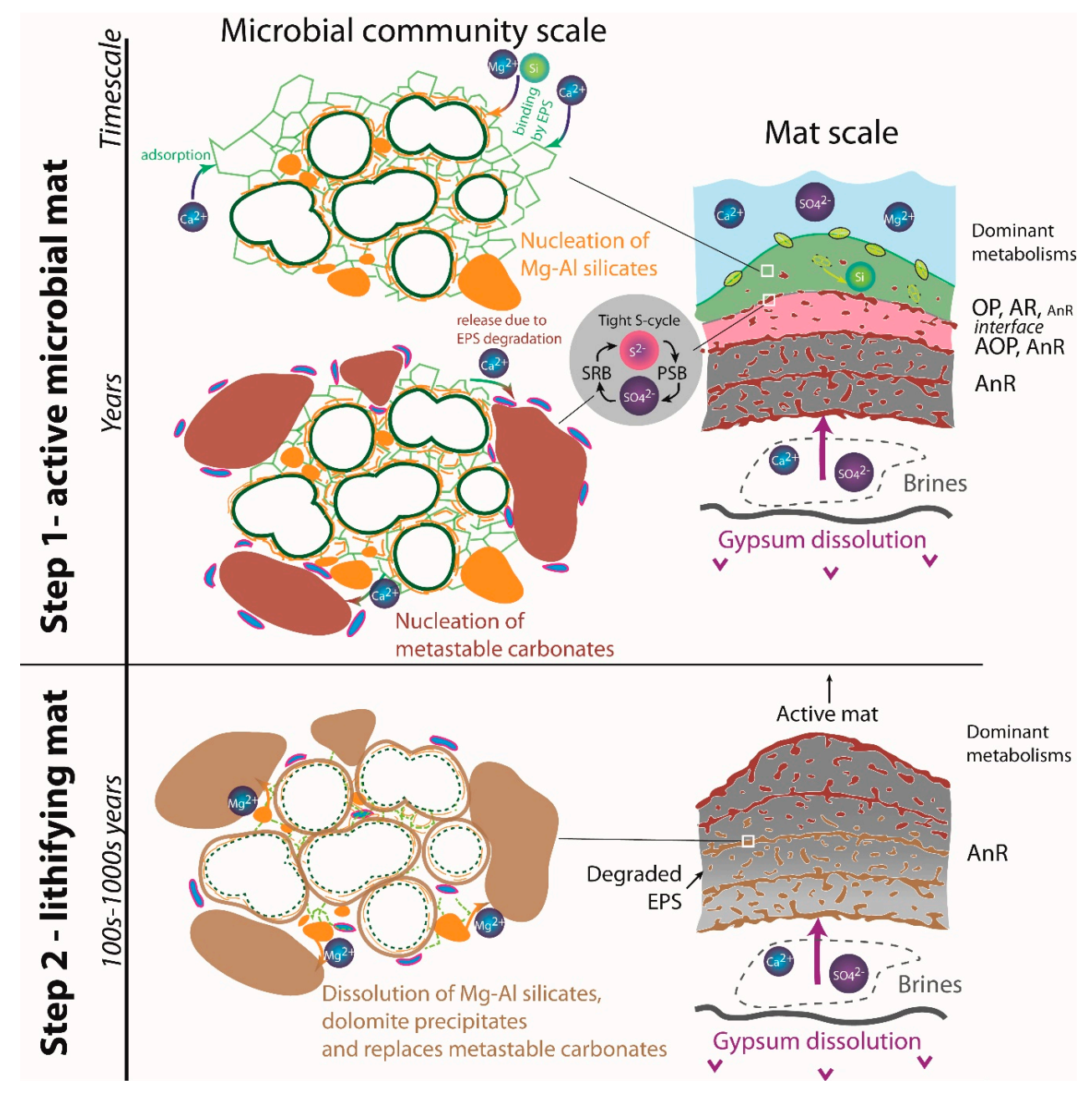

Figure 20. Cont. 


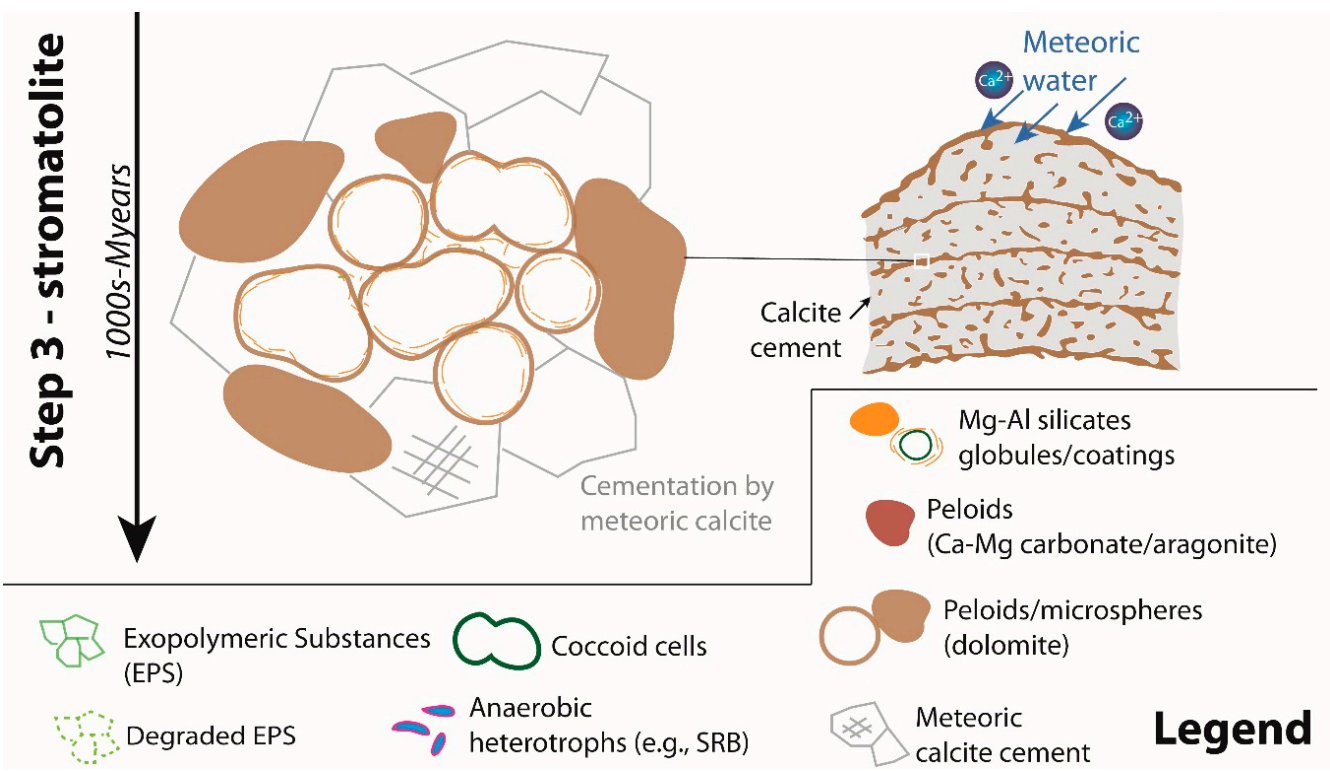

Figure 20. Geomicrobiological scenario explaining the formation of typical TCC microbialites at two scales: (i) the microbial mat (at this scale, the model explains the formation of the laminated peloidal microfabric (Figure 4)); and (ii) the microbial community (at this scale, the model describes the formation of peloids and microspheres and the evolution of mineral phases through diagenesis (paragenesis)). The scenario implies classical cation sources (surface water, silicate alteration) plus hypogenic sulfate-rich brines derived from Messinian gypsum dissolution. The formation of microbialites is divided into three steps. Step 1: Depositional microbial processes. At this stage, a layered microbial mat develops. Microbial layering depends on light and chemical gradients. The surface/green layer (i.e., the first millimeters) of the mat is constituted of oxygenic phototrophs (OP), in that case cyanobacteria and diatoms, producing abundant EPS that bind calcium. The photosynthetic activity increases the $\mathrm{pH}$ (>9), leading to the dissolution of diatoms and to the nucleation of $\mathrm{Mg}$ - $\mathrm{Al}$ silicates on the sheath of coccoid cyanobacteria, but also as globules within EPS. Aerobic respirers (AR) quickly consume oxygen, leading to the formation of an anoxic zone below the green layer. The red layer is dominated by anoxygenic photosynthesizers (AOP), potentially purple sulfur bacteria. Anaerobic respirers (AnR) are distributed in the whole mat, but are particularly active in the red and black layers. In the red layer, a synergy between purple sulfur bacteria and sulfate reducing bacteria leads to rapid sulfur cycling and increasing alkalinity. This synergy is fueled by sulfates coming from surface water, but also by seepage produced by the dissolution of the underlying gypsum. A metastable carbonate lamina develops at the interface between the green and red layer, where both $\mathrm{pH}$ and alkalinity are elevated. Metastable carbonate peloids nucleate in the red and black layers following the local degradation of EPS by AnR (including sulfate reducing bacteria) and subsequent release of calcium ions. The alternance between peloids and lamina results in the formation of a laminated peloidal microfabric. The process will then repeat over time through upward growth of the microbial mat. Step 2: Early diagenetic transformations. These transformations occur in the shallow subsurface (a few centimeters to meters deep) during the centuries to millennia following the initial mat development (Step 1). EPS are increasingly degraded through reduced, but still active AnR activity, inducing a lowering of porewater $\mathrm{pH}(<7)$. In such conditions, $\mathrm{Mg}-\mathrm{Al}$ silicates are partially to totally dissolved. A reaction between the released magnesium ions and degraded EPS leads to the replacement of metastable carbonates by dolomite. Step 3: Late diagenesis. Following the circulation of meteoric water in the rock, a calcite cement develops inside the stromatolite and fills part of the remaining porosity.

The microbialites of the TCC were predominantly composed of dolomite (Figure 10). The formation of dolomite is very uncommon in present-day surface conditions because of the complexation of $\mathrm{Mg}^{2+}$ by water and sulfates $[113,114]$, but also due to the configuration of the dolomite lattice, limiting the incorporation of $\mathrm{Mg}$ at ambient pressure [115]. Some microbial metabolisms and EPS characteristics 
could allow overcoming such limitations. For example, SRB combined with a control of the EPS on the incorporation of $\mathrm{Mg}^{2+}$ ions could be involved in dolomite production in Brazilian coastal lagoons [116,117]. However, these examples show a limited potential for cyanobacteria preservation. Kenward et al. [118,119] and Roberts et al. [120] showed through cell culture experiments that carboxyl group-rich organic substrates (e.g., methanogenic archaeal cell walls) are a favorable surface for stable dolomite nucleation at low temperature in moderately supersaturated solutions. Carboxyl groups, which can be abundantly produced in EPS under hypersaline conditions [120], can break Mg-water bonds by complexing $\mathrm{Mg}^{2+}$, making it available for dolomite precipitation.

In modern microbialites, the first carbonate phases precipitate quickly (i.e., within months) [16], but are often metastable (e.g., aragonite, $\mathrm{Ca}-\mathrm{Mg}$ carbonates), and so have a low preservation potential. In the Great Salt Lake, aragonite precipitates following EPS degradation by heterotrophs and forms millimeter large patches embedding coccoid cyanobacteria [20]. Aragonite is subsequently partially to fully replaced by dolomite in less than $2 \mathrm{ky}$ i.e., during early diagenesis, resulting in the formation of dolomite microspheres (Figure 19H). Dolomite precipitation could result from a reaction between degraded EPS, aragonite, and dissolving $\mathrm{Mg}$ silicates in slightly acidic porewater ( $\mathrm{pH}$ of ca. 6.5) [20]. The quality of the preservation of coccoid cyanobacteria microfossils in some TCC stromatolites (Figures 16 and 17A-E) implies a very early mineralization of cells. Bacterial walls can be negatively charged, e.g., due to the presence of carboxyl groups, which allow the active or passive binding of metallic cations, especially $\mathrm{Ca}^{2+}$ and $\mathrm{Mg}^{2+}$. Such binding deactivates autolytic enzymes and subsequently slows cell decay and facilitates its preservation [121,122]. An initial coating of cyanobacteria by Mg silicates could help in their preservation in the sedimentary record [88,89]. This type of silicate is scarce in TCC microbialites (Figure 17A-E), but could have been initially abundant. In our scenario, $\mathrm{Mg}$ - $\mathrm{Al}$ silicates precipitate and coat coccoid cells in the oxygenic photosynthetic zone and at the oxygenic-anoxygenic photosynthetic where the $\mathrm{pH}$ is high (Figure 20; Step 1). The dissolution of diatom frustules, which are unstable in porewater at elevated $\mathrm{pH}(>9)$, could be a significant source of silica [20]. A few centimeters to a few meters deep in the mat (Figure 20; Step 2), Mg-Al silicates become unstable due to a lower $\mathrm{pH}$ $(<7)$. The reaction between (i) magnesium ions released from $\mathrm{Mg}$-Al silicate dissolution, (ii) calcium ions delivered by the dissolution of a metastable carbonate phase, and (iii) degraded EPS (potentially rich in carboxyl sites) could lead to the precipitation of dolomite. In the case of coccoid microspheres, the dolomite envelope could nucleate directly on a former $\mathrm{Mg}$ - $\mathrm{Al}$ silicate coating. The last step of TCC microbialite formation (Figure 20; Step 3) is the partial cementation of remaining porosity by calcite cements, likely precipitated in meteoric water.

The bloom of microbialites characterizing the Terminal Carbonate Complex was contemporaneous with gypsum dissolution in all the marginal basins of southeastern Spain (Figure 2B) [27,30]. It was previously demonstrated that Messinian saline brines had a role in secondary, mixing-type dolomitization of non-microbial facies, e.g., ooid grainstones [67]. Here, we hypothesized that the dissolution of the Messinian gypsum and subsequent sulfate-rich (and calcium) brine seepage could have supported the sulfur cycle in TCC microbialites (Figure 20), leading to massive microbial dolomite production. Hypogenic sulfate-rich seepage could have led to other extensive microbial dolomite deposits associated with evaporite giants in the sedimentary record, e.g., the Neoproterozoic-Early Cambrian Ara Group (Oman) [123,124] and the Permian Zechstein Group (North Sea, England, Germany, Netherlands) [125].

\section{Conclusions}

A regional sedimentological and stratigraphic study of the Messinian microbialites of the Terminal Carbonate Complex demonstrated the potential impact of sedimentary dynamics on the fabrics and composition of fossil microbial buildups. Two microbialites morphological groups were recognized: (1) Microbialite Association 1 was dominated by slow-growing forms forming (sub-) continuous coverage at the periphery of protected, low energy hypersaline lagoons or lakes; (2) Microbialite Association 2 was composed of disconnected, high relief forms, preventing burial by growing fast in 
wave and tide dominated ooid shoals, where sediment motion was permanent and intense. A similar dichotomy is observed in the present-day Caribbean hypersaline lagoons and open marine sand shoals, confirming that microbialites are powerful paleoenvironmental indicators. The stratigraphic distribution of MA1 and MA2 was strongly controlled by water level variations, but also by the nature and the geometry of the inherited substratum (e.g., gypsum vs. coral reefs). MA1 was predominant during third to fourth order early transgressions and late regressions. MA2 favorably developed over substrata exposed to strong waves (e.g., coral reefs) during third to fourth late transgressions and early regressions. Microfabrics of the studied microbialites suggested that they mostly accreted through microbially-mediated precipitation. Grain trapping and binding were volumetrically significant near continental detrital grain sources or in high energy sand/ooid/pellet shoals. Microbial mineral products were preserved mainly as dolomite, allowing a partial reconstruction of microbial communities and activity. Dolomite habitus reflected either (1) precipitation within extracellular polymeric substance (EPS) (e.g., peloids, dumbbells) or (2) permineralized bacteria, e.g., filamentous cyanobacteria preserved as micro-columns, or coccoids in the form of microspheres made of dolomite and remains of $(\mathrm{Ca}) \mathrm{Mg}-\mathrm{Al}$ silicates. Finally, we proposed a scenario linking microbial activity, microbialite fabrics, and mineralogy with the paleoenvironmental evolution of the carbonate platform and underlying gypsum deposits. We proposed that massive dolomite production was enhanced by the activity of sulfate reducing bacteria supported by sulfate seepage during platform scale syn-sedimentary dissolution of the Messinian gypsum substratum. This work showed that subsurface brine recycling has to be taken into account when one attempts to interpret ancient dolomite-rich microbial episodes.

Supplementary Materials: The following are available online at http://www.mdpi.com/2075-163X/10/3/276/s1. Table S1: GPS location (degree; minute; seconds) of the eight outcrops used for this study. Table S2: Mineralogical composition (based on XRD and thin section point counting) of the microbialite samples used in this.

Author Contributions: Project design R.B., E.V., J.-M.R., and P.T.V.; fieldwork, sampling, sedimentology, and stratigraphy, R.B., E.V., and J-M.R.; thin section and XRD preparation, P.B.; petrographic and mineralogic interpretations, R.B., A.P.A., and P.P.; SEM analyses, R.B.; X-ray micro- and nano-tomography A.F., D.B., and J.L.; comparison with modern sedimentary systems R.B., E.V., C.D., A.P., and P.T.V.; writing, original draft preparation, R.B.; writing, review and editing, R.B., E.V., C.D., A.P., J-M.R., A.F., P.P. and P.T.V. All authors have read and agreed to the published version of the manuscript.

Funding: This research received no external funding.

Acknowledgments: The authors thank Vincent Rommevaux (MNHN, Paris) for the preparation of thin sections and for the good times spent in the field, Claudie Josse (Institut Carnot de Bourgogne, Dijon) and Frédéric Marin (Biogéosciences, Dijon) for their contribution to sample preparation and SEM analyses, and Maxime Virolle, Dylan Chaillot, Grégoire Bex, Flora Guillemaut, and Alice Gotrand for their participation in the fieldwork and laboratory analyses.

Conflicts of Interest: The authors declare no conflict of interest.

\section{References}

1. Allwood, A.C.; Walter, M.R.; Kamber, B.S.; Marshall, C.P.; Burch, I.W. Stromatolite reef from the early archaean era of Australia. Nature 2006, 441, 714-718. [CrossRef]

2. Nutman, A.P.; Bennett, V.C.; Friend, C.R.L.; Van Kranendonk, M.J.; Chivas, A.R. Rapid emergence of life shown by discovery of 3700-million-year-old microbial structures. Nature 2016, 537, 535-538. [CrossRef]

3. Nutman, A.P.; Bennett, V.C.; Friend, C.R.L.; Van Kranendonk, M.J.; Rothacker, L.; Chivas, A.R. Cross-examining Earth's oldest stromatolites: Seeing through the effects of heterogeneous deformation, metamorphism and metasomatism affecting Isua (Greenland) 3700 Ma sedimentary rocks. Precambrian Res. 2019, 331, 105347. [CrossRef]

4. Des Marais, D.J. Evolution-When did photosynthesis emerge on earth? Science 2000, 289, $1703-1705$.

5. Arp, G.; Reimer, A.; Reitner, J. Photosynthesis-induced biofilm calcification and calcium concentrations in phanerozoic oceans. Science 2001, 292, 1701-1704. [CrossRef]

6. Aloisi, G. The calcium carbonate saturation state in cyanobacterial mats throughout Earth's history. Geochim. Cosmochim. Acta 2008, 72, 6037-6060. [CrossRef] 
7. Dupraz, C.; Visscher, P.T. Microbial lithification in marine stromatolites and hypersaline mats. Trends Microbiol. 2005, 13, 429-438. [CrossRef]

8. Riding, R. Microbial carbonate abundance compared with fluctuations in metazoan diversity over geological time. Sediment. Geol. 2006, 185, 229-238. [CrossRef]

9. Power, I.M.; Harrison, A.L.; Dipple, G.M.; Wilson, S.A.; Kelemen, P.B.; Hitch, M.; Southam, G. Carbon mineralization: From natural analogues to engineered systems. Rev. Mineral. Geochem. 2013, 77, 305-360. [CrossRef]

10. Dravis, J.J. Hardened subtidal stromatolites, Bahamas. Science 1983, 219, 385-386. [CrossRef]

11. Reid, R.P.; Visscher, P.T.; Decho, A.W.; Stolz, J.F.; Bebout, B.M.; Dupraz, C.; Macintyre, I.G.; Paerl, H.W.; Pinckney, J.L.; Prufert-Bebout, L.; et al. The role of microbes in accretion, lamination and early lithification of modern marine stromatolites. Nature 2000, 406, 989-992. [CrossRef]

12. Visscher, P.T.; Reid, R.P.; Bebout, B.M.; Hoeft, S.E.; Macintyre, I.G.; Thompson, J.A. Formation of lithified micritic laminae in modern marine stromatolites (Bahamas): The role of sulfur cycling. Am. Miner. 1998, 83, 1482-1493. [CrossRef]

13. Dupraz, C.; Visscher, P.T.; Baumgartner, L.K.; Reid, R.P. Microbe-mineral interactions: Early carbonate precipitation in a hypersaline lake (Eleuthera Island, Bahamas). Sedimentology 2004, 51, 745-765. [CrossRef]

14. Glunk, C.; Dupraz, C.; Braissant, O.; Gallagher, K.L.; Verrecchia, E.P.; Visscher, P.T. Microbially mediated carbonate precipitation in a hypersaline lake, Big Pond (Eleuthera, Bahamas). Sedimentology 2011, 58, 720-736. [CrossRef]

15. Bouton, A.; Vennin, E.; Pace, A.; Bourillot, R.; Dupraz, C.; Thomazo, C.; Brayard, A.; Désaubliaux, G.; Visscher, P.T. External controls on the distribution, fabrics and mineralization of modern microbial mats in a coastal hypersaline lagoon, Cayo Coco (Cuba). Sedimentology 2016, 63, 972-1016. [CrossRef]

16. Pace, A.; Bourillot, R.; Bouton, A.; Vennin, E.; Braissant, O.; Dupraz, C.; Duteil, T.; Bundeleva, I.; Patrier, P.; Galaup, S.; et al. Formation of stromatolite lamina at the interface of oxygenic-anoxygenic photosynthesis. Geobiology 2018, 16, 378-398. [CrossRef]

17. Bouton, A.; Vennin, E.; Boulle, J.; Pace, A.; Bourillot, R.; Thomazo, C.; Brayard, A.; Désaubliaux, G.; Goslar, T.; Yokoyama, Y.; et al. Linking the distribution of microbial deposits from the Great Salt Lake (Utah, USA) to tectonic and climatic processes. Biogeosciences 2016, 13, 5511-5526. [CrossRef]

18. Grotzinger, J.P.; Knoll, A.H. Stromatolites in Precambrian carbonates: Evolutionary mileposts or environmental dipsticks? Annu. Rev. Earth Planet. Sci. 1999, 27, 313-358. [CrossRef]

19. Dupraz, C.; Reid, R.P.; Braissant, O.; Decho, A.W.; Norman, R.S.; Visscher, P.T. Processes of carbonate precipitation in modern microbial mats. Earth Sci. Rev. 2009, 96, 141-162. [CrossRef]

20. Pace, A.; Bourillot, R.; Bouton, A.; Vennin, E.; Galaup, S.; Bundeleva, I.; Patrier, P.; Dupraz, C.; Thomazo, C.; Sansjofre, P.; et al. Microbial and diagenetic steps leading to the mineralisation of Great Salt Lake microbialites. Sci. Rep. 2016, 6, 31495. [CrossRef]

21. Sforna, M.C.; Daye, M.; Philippot, P.; Somogyi, A.; van Zuilen, M.A.; Medjoubi, K.; Gérard, E.; Jamme, F.; Dupraz, C.; Braissant, O.; et al. Patterns of metal distribution in hypersaline microbialites during early diagenesis: Implications for the fossil record. Geobiology 2017, 15, 259-279. [CrossRef] [PubMed]

22. Sanz-Montero, M.E.; Rodriguez-Aranda, J.P.; Garcia Del Cura, M.A. Dolomite-silica stromatolites in Miocene lacustrine deposits from the Duero Basin, Spain: The role of organotemplates in the precipitation of dolomite. Sedimentology 2008, 55, 729-750. [CrossRef]

23. Esteban, M. Significance of the upper miocene coral reefs of the western mediterranean. Palaeogeogr. Palaeoclimatol. Palaeoecol. 1979, 29, 169-188. [CrossRef]

24. Rouchy, J.-M.; Saint Martin, J.-P. Late Miocene events in the mediterranean as recorded by carbonate-evaporite relations. Geology 1992, 20, 629-632. [CrossRef]

25. Braga, J.C.; Martin, J.M.; Riding, R. Controls on microbial dome fabric along a carbonate-siliciclastic shelf-basin transect, Miocene, SE Spain. Palaios 1995, 10, 347-361. [CrossRef]

26. Franseen, E.K.; Goldstein, R.H.; Farr, M.R. Quantitative controls on location and architecture of carbonate depositional sequences. J. Sediment. Res. 1998, 68, 283-298. [CrossRef]

27. Bourillot, R.; Vennin, E.; Rouchy, J.-M.; Blanc-Valleron, M.-M.; Caruso, A.; Durlet, C. The end of the Messinian Salinity Crisis in the western Mediterranean: Insights from the carbonate platforms of south-eastern Spain. Sediment. Geol. 2010, 229, 224-253. [CrossRef] 
28. Mas, G.; Fornós, J. La Crisis de Salinidad del Messiniense en la cuenca sedimentaria de Palma (Mallorca, Islas Baleares). Geogaceta 2012, 52, 57-60.

29. Esteban, M.; Braga, J.C.; Martin, J.; de Santisteban, C. Western mediterranean reef complexes. In Models for Carbonate Stratigraphy from Miocene Reef Complexes of Mediterranean Regions; Franseen, E.K., Esteban, M., Ward, W.C., Rouchy, J.M., Eds.; Concepts in Sedimentology and Paleontology; SEPM: Tulsa, OK, USA, 1996; Volume 5, pp. 56-72.

30. Bourillot, R.; Vennin, E.; Rouchy, J.M.; Durlet, C.; Rommevaux, V.; Kolodka, C.; Knap, F. Structure and evolution of a Messinian mixed carbonate-siliciclastic platform: The role of evaporites (Sorbas Basin, South-east Spain). Sedimentology 2010, 57, 477-512. [CrossRef]

31. Lipinski, C.J.; Franseen, E.K.; Goldstein, R.H. Reservoir analog model for oolite-microbialite sequences, Miocene terminal carbonate complex, Spain. AAPG Bull. 2013, 97, 2035-2057. [CrossRef]

32. Feldmann, M.; McKenzie, J.A. Messinian stromatolite-thrombolite associations, Santa Pola, SE Spain: An analogue for the palaeozoic? Sedimentology 1997, 44, 893-914. [CrossRef]

33. Riding, R.; Braga, J.C.; Martin, J.M. Oolite stromatolites and thrombolites, Miocene, Spain: Analogue of Recent giant Bahamian examples. Sediment. Geol. 1991, 71, 121-127. [CrossRef]

34. Vasconcelos, C.; McKenzie, J.A. Microbial mediation of modern dolomite precipitation and diagenesis under anoxic conditions (Lagoa Vermelha, Rio de Janeiro, Brazil). J. Sediment. Res. 1997, 67, 378-390.

35. Van Lith, Y.; Warthmann, R.; Vasconcelos, C.; McKenzie, J.A. Sulphate-reducing bacteria induce low-temperature Ca-dolomite and high Mg-calcite formation. Geobiology 2003, 1, 71-79. [CrossRef]

36. Bontognali, T.R.R.; Vasconcelos, C.; Warthmann, R.J.; Lundberg, R.; McKenzie, J.A. Dolomite-mediating bacterium isolated from the sabkha of Abu Dhabi (UAE). Terra Nova 2012, 24, 248-254. [CrossRef]

37. Gebelein, C.D.; Hoffman, P. Algal origin of dolomite laminations in stromatolitic limestones. J. Sediment. Petrol. 1973, 43, 603-613.

38. Krijgsman, W.; Fortuin, A.R.; Hilgen, F.J.; Sierro, F.J. Astrochronology for the Messinian Sorbas basin (SE Spain) and orbital (precessional) forcing for evaporite cyclicity. Sediment. Geol. 2001, 140, 43-60. [CrossRef]

39. Rouchy, J.M.; Caruso, A. The Messinian salinity crisis in the Mediterranean basin: A reassessment of the data and an integrated scenario. Sediment. Geol. 2006, 188-189, 35-67. [CrossRef]

40. Esteban, M. Guia de campo del arrecife messiniense de Santa Pola. 1977; 1-50.

41. Bourillot, R. Evolution des Plates-Formes Carbonatées Pendant la crise de Salinité Messinienne: De la Déformation des Évaporites aux Communautés Microbialithiques (Sud-Est de l'Espagne). Unpublished. Ph.D. Thesis, Université de Bourgogne, Dijon, France, 2009.

42. Ott d'Estevou, P.; Montenat, C. Le bassin de Sorbas-Tabernas. In Les bassins Neogènes du domaine Bétique oriental (Espagne). Tectonique et Sédimentation Dans un Couloir de Décrochement. Première partie: Étude Régionale; Montenat, C., Ed.; Documents et travaux de L'IGAL; IGAL: Paris, France, 1990; Volume 12-13, pp. 101-128.

43. Burne, R.V.; Moore, L.S. Microbialites; organosedimentary deposits of benthic microbial communities. Palaios 1987, 2, 241-254. [CrossRef]

44. Kalkowsky, E. Oolith und stromatolith in norddeutschen buntsandstein. Dtsch. Geol. Ges. 1908, 60, 68-125.

45. Aitken, J.D. Classification and environmental significance of cryptalgal limestones and dolomites with illustrations from the Cambrian and Ordovician of southwestern Alberta. J. Sediment. Petrol. 1967, 37, 1163-1178. [CrossRef]

46. Monty, C. Le Miocène supérieur de la région de Benejuzar (Province d'Alicante) et stromatolithes associés. Ann. Société Géologique Belg. 1981, 104, 109-114.

47. Rouchy, J.M. La Genèse des Évaporites Messiniennes de Méditerannée; Mémoires du Muséum National d'Histoire Naturelle: Paris, France, 1982; Volume L.

48. Dickson, J.A.D. Carbonate identification and genesis as revealed by staining. J. Sediment. Res. 1966, 36, 491-505.

49. Al-Hashimi, W.S.; Hemingway, J.E. Recent dedolomitization and the origin of the rusty crusts of Northumberland. J. Sediment. Res. 1973, 43, 82-91. [CrossRef]

50. Lumsden, D.N. Discrepancy between thin-section and X-ray estimates of dolomite in limestone. J. Sediment. Res. 1979, 49, 429-435.

51. Roduit, N. Jmicrovision: Un Logiciel D'analyse D'images Pétrographiques Polyvalent; Université de Genève: Genève, Geneva, 2007. 
52. Braga, J.C.; Martín, J.M. Subaqueous siliciclatic stromatolites: A case history from Late Miocene beach deposits in the Sorbas Basin of SE Spain. In Microbial Sediments; Riding, R., Awramik, S.M., Eds.; Springer: Berlin/Heidelberg, Germany, 2000.

53. Goldstein, R.H.; Franseen, E.K.; Lipinski, C.J. Topographic and sea level controls on oolite-microbialite-coralgal reef sequences: The terminal carbonate complex of southeast Spain. AAPG Bull. 2013, 97, 1997-2034. [CrossRef]

54. Calvet, F.; Zamarreno, I.; Vallès, D. Late Miocene reefs of the Alicante-Elche basin, southeast Spain. In Models for Carbonate Stratigraphy from Miocene of Mediterranean Regions; Franseen, E.K., Esteban, M., Ward, W.C., Rouchy, J.M., Eds.; SEPM: Tulsa, OK, USA, 1996; pp. 177-190.

55. Reid, R.P.; James, N.P.; Macintyre, I.G.; Dupraz, C.P.; Burne, R.V. Shark Bay stromatolites: Microfabrics and reinterpretation of origins. Facies 2003, 49, 299-324. [CrossRef]

56. Roche, A.; Vennin, E.; Bouton, A.; Olivier, N.; Wattinne, A.; Bundeleva, I.; Deconinck, J.-F.; Virgone, A.; Gaucher, E.C.; Visscher, P.T. Oligo-Miocene lacustrine microbial and metazoan buildups from the Limagne Basin (French Massif Central). Palaeogeogr. Palaeoclimatol. Palaeoecol. 2018, 504, 34-59. [CrossRef]

57. Andres, M.S.; Reid, P.R. Growth morphologies of modern marine stromatolites: A case study from Highborne Cay, Bahamas. Sediment. Geol. 2006, 185, 319-328. [CrossRef]

58. Vennin, E.; Bouton, A.; Bourillot, R.; Pace, A.; Roche, A.; Brayard, A.; Thomazo, C.; Virgone, A.; Gaucher, E.C.; Desaubliaux, G.; et al. The lacustrine microbial carbonate factory of the successive Lake Bonneville and Great Salt Lake, Utah, USA. Sedimentology 2019, 66, 165-204. [CrossRef]

59. Planavsky, N.; Ginsburg, R.N. Taphonomy of modern marine bahamian microbialites. Palaios 2009, $24,5-17$. [CrossRef]

60. Bernhard, J.M.; Edgcomb, V.P.; Visscher, P.T.; McIntyre-Wressnig, A.; Summons, R.E.; Bouxsein, M.L.; Louis, L.; Jeglinski, M. Insights into foraminiferal influences on microfabrics of microbialites at Highborne Cay, Bahamas. Proc. Natl. Acad. Sci. USA 2013, 110, 9830-9834. [CrossRef] [PubMed]

61. Planavsky, N.; Reid, R.P.; Lyons, T.W.; Myshrall, K.L.; Visscher, P.T. Formation and diagenesis of modern marine calcified cyanobacteria. Geobiology 2009, 7, 566-576. [CrossRef] [PubMed]

62. Dupraz, C.; Strasser, A. Microbialites and micro-encrusters in shallow coral bioherms (Middle to Late Oxfordian, Swiss Jura Mountains). Facies 1999, 40, 101-129. [CrossRef]

63. Dupraz, C.; Strasser, A. Nutritional modes in coral-microbialite reefs (Jurassic, Oxfordian, Switzerland): Evolution of trophic structure as a response to environmental change. Facies 2002, 17, 449-471. [CrossRef]

64. Camoin, G.; Cabioch, G.; Eisenhauer, A.; Braga, J.C.; Hamelin, B.; Lericolais, G. Environmental significance of microbialites in reef environments during the last deglaciation. Sediment. Geol. 2006, 185, 277-295. [CrossRef]

65. Bourillot, R.; Vennin, E.; Kolodka, C.; Rouchy, J.M.; Caruso, A.; Durlet, C.; Chaix, C.; Rommevaux, V. The role of topography and erosion in the development and architecture of shallow-water coral bioherms (Tortonian-Messinian, Cabo de Gata, SE Spain). Palaeogeogr. Palaeoclimatol. Palaeoecol. 2009, 281, 92-114. [CrossRef]

66. Roep, T.B.; Dabrio, C.J.; Fortuin, A.R.; Polo, M.D. Late highstand patterns of shifting and stepping coastal barriers and washover-fans (late Messinian, Sorbas basin, SE Spain). Sediment. Geol. 1998, 116, 27-56. [CrossRef]

67. Meyers, W.J.; Lu, F.H.; Zachariah, J.K. Dolomitization by mixed evaporative brines and freshwater, Upper Miocene carbonates, Nijar, Spain. J. Sediment. Res. 1997, 67, 898-912.

68. Monty, C. The origin and development of cryptalgal fabrics. In Stromatolites; Walter, M.R., Ed.; Sptinger: Berlin, Germany, 1976; pp. 193-249.

69. Gerdes, G.; Krumbein, W.E. Peritidal potential stromatolites-A synopsis. In Phanerozoic Stromatolites II; Bertrand-Sarfati, J., Monty, C., Eds.; Kluwer Academic Publishers: Dordrecht, The Netherlands; Boston, MA, USA; London, UK, 1994; pp. 101-129.

70. Arp, G.; Reimer, A.; Reitner, J. Microbialite formation in seawater of increased alkalinity, satonda crater Lake, indonesia. J. Sediment. Res. 2003, 73, 105-127. [CrossRef]

71. Flügel, E. Microfacies of Carbonate Rocks; Springer: Berlin, Germany, 2004.

72. Trichet, J.; Défarge, C.; Tribble, J.; Tribble, G.; Sansone, F. Christmas island lagoonal lakes, models for the deposition of carbonate-evaporite-organic laminated sediments. Sediment. Geol. 2001, 140, 177-189. [CrossRef] 
73. Spadafora, A.; Perri, E.; McKenzie, J.A.; Vasconcelos, C. Microbial biomineralization processes forming modern Ca:Mg carbonate stromatolites. Sedimentology 2010, 57, 27-40. [CrossRef]

74. Riding, R. Calcified cyanobacteria. In Calcareous Algae and Stromatolites; Riding, R., Ed.; Springer: Berlin, Germany, 1991; pp. 55-87.

75. Davaud, E.; Strasser, A.; Jedoui, Y. Stromatolite and serpulid bioherms in a holocene restricted lagoon. In Stromatolites II; Bertrand Sarfati, J., Monty, C., Eds.; Springer: Dordrecht, The Nerterlands, 1994; pp. 131-151.

76. Dupraz, C.; Fowler, A.; Tobias, C.; Visscher, P.T. Stromatolitic knobs in Storr's Lake (San Salvador, Bahamas): A model system for formation and alteration of laminae. Geobiology 2013, 11, 527-548. [CrossRef]

77. Bertrand-Sarfati, J.; Freytet, P.; Plaziat, J. Microstructures in Tertiary nonmarine stromatolites (France). Comparison with Proterozoic. In Stromatolites II; Bertrand Sarfati, J., Monty, C., Eds.; Springer: Dordrecht, The Nerterlands, 1994.

78. Rasmussen, K.A.; Macintyre, I.G.; Prufert, L. Modern stromatolite reefs fringing a brackish coastline, Chetumal Bay, Belize. Geology 1993, 21, 199-202. [CrossRef]

79. Freytet, P.; Verrecchia, E.P. Freshwater organisms that build stromatolites: A synopsis of biocrystallization by prokaryotic and eukaryotic algae. Sedimentology 1998, 45, 535-563. [CrossRef]

80. Gallagher, K.L.; Kading, T.J.; Braissant, O.; Dupraz, C.; Visscher, P.T. Inside the alkalinity engine: The role of electron donors in the organomineralization potential of sulfate-reducing bacteria. Geobiology 2012, 10, 518-530. [CrossRef]

81. Jones, B.; Peng, X. Multiphase calcification associated with the atmophytic cyanobacterium Scytonema julianum. Sediment. Geol. 2014, 313, 91-104. [CrossRef]

82. Bouton, A.; Vennin, E.; Amiotte-Suchet, P.; Thomazo, C.; Sizun, J.-P.; Virgone, A.; Gaucher, E.C.; Visscher, P.T. Prediction of the calcium carbonate budget in a sedimentary basin: A "source-to-sink" approach applied to Great Salt Lake, Utah, USA. Basin Res. 2019. [CrossRef]

83. Gebelein, C.D. Distribution, morphology, and accretion rate of recent subtidal algal stromatolites, Bermuda. J. Sediment. Res. 1969, 39, 49-69.

84. Golubic, S.; Focke, J.W. Phormidium hendersonii Howe; identity and significance of a modern stromatolite building microorganism. J. Sediment. Res. 1978, 48, 751-764.

85. Macintyre, I.G.; Prufert-Bebout, L.; Reid, R.P. The role of endolithic cyanobacteria in the formation of lithified laminae in Bahamian stromatolites. Sedimentology 2000, 47, 915-921. [CrossRef]

86. Awramik, S.M. Stromatolites with Coccoid and Filamentous Blue-Green Algae of Messinian Age From Site 374-Ionian Abyssal Plain; In Initial Reports; DSDP: Washington, WA, USA, 1978; Volume 1, pp. 665-668.

87. Défarge, C.; Trichet, J.; Couté, A. On the appearance of cyanobacterial calcification in modern stromatolites. Sed. Geol. 1994, 94, 11-19. [CrossRef]

88. Zeyen, N.; Benzerara, K.; Li, J.; Groleau, A.; Balan, E.; Robert, J.-L.; Estève, I.; Tavera, R.; Moreira, D.; López-García, P. Formation of low-T hydrated silicates in modern microbialites from Mexico and implications for microbial fossilization. Front. Earth Sci. 2015, 3, 64. [CrossRef]

89. Burne, R.V.; Moore, L.S.; Christy, A.G.; Troitzsch, U.; King, P.L.; Carnerup, A.M.; Hamilton, P.J. Stevensite in the modern thrombolites of Lake Clifton, Western Australia: A missing link in microbialite mineralization? Geology 2014, 42, 575-578. [CrossRef]

90. Visscher, P.T.; Dupraz, C.; Braissant, O.; Gallagher, K.L.; Glunk, C.; Casillas, L.; Reed, R.E.S. Biogeochemistry of carbon cycling in hypersaline mats: Linking the present to the past through biosignatures. In Microbial Mats: Modern and Ancient Microorganisms in Stratified Systems; Seckbach, J., Oren, A., Eds.; Springer Netherlands: Dordrecht, The Netherlands, 2010; pp. 443-468, ISBN 978-90-481-3799-2.

91. Mann, C.J.; Nelson, W.M. Microbialitic structures in Storr's Lake, San Salvador island, Bahamas Islands. Palaios 1989, 4, 287-293. [CrossRef]

92. Myshrall, K.L.; Mobberley, J.M.; Green, S.J.; Visscher, P.T.; Havemann, S.A.; Reid, R.P.; Foster, J.S. Biogeochemical cycling and microbial diversity in the thrombolitic microbialites of Highborne Cay, Bahamas. Geobiology 2010, 8, 337-354. [CrossRef]

93. Dupraz, C.; Pattisina, R.; Verrecchia, E.P. Translation of energy into morphology: Simulation of stromatolite morphospace using a stochastic model. Microb. Microb. Commun. 2006, 185, 185-203. [CrossRef]

94. Dill, R.F.; Shinn, E.A.; Jones, A.T.; Kelly, K.; Steinen, R.P. Giant subtidal stromatolites forming in normal salinity waters. Nature 1986, 324, 55-58. [CrossRef] 
95. Bowlin, E.M.; Klaus, J.S.; Foster, J.S.; Andres, M.S.; Custals, L.; Reid, R.P. Environmental controls on microbial community cycling in modern marine stromatolites. Sediment. Geol. 2012, 263, 45-55. [CrossRef]

96. Reid, P.R.; MacIntyre, I.G. Steneck A microbialite/algal ridge fringing reef complex, Highborne Cay, Bahamas. Atoll Res. Bull. 1999, 465, 1-18. [CrossRef]

97. Tarhan, L.G.; Planavsky, N.J.; Laumer, C.E.; Stolz, J.F.; Reid, R.P. Microbial mat controls on infaunal abundance and diversity in modern marine microbialites. Geobiology 2013, 11, 485-497. [CrossRef]

98. Kolodka, C.; Vennin, E.; Bourillot, R.; Granjeon, D.; Desaubliaux, G. Stratigraphic modelling of platform architecture and carbonate production: A Messinian case study (Sorbas Basin, SE Spain). Basin Res. 2016, 28, 658-684. [CrossRef]

99. Atwood, G.; Wambeam, T.J.; Anderson, N.J. Chapter 1-The present as a key to the past: Paleoshoreline correlation insights from great salt lake. In Developments in Earth Surface Processes; Oviatt, C.G., Shroder, J.F., Eds.; Elsevier: Amsterdam, The Netherlands, 2016; Volume 20, pp. 1-27, ISBN 0928-2025.

100. Baskin, R.; Wright, V.P.; Driscoll, N.; Kent, G.; Hepner, G. Microbialite bioherms in Great Salt Lake, Utah: Influence of active tectonics and anthropogenic effects. In Proceedings of the American Association of Petroleum Geologists Heidelberg Conference, Heidelberg, Germany, 4-8 June 2012.

101. Bouton, A.; Vennin, E.; Mulder, T.; Pace, A.; Bourillot, R.; Thomazo, C.; Brayard, A.; Goslar, T.; Buoncristiani, J.-F.; Désaubliaux, G.; et al. Enhanced development of lacustrine microbialites on gravity flow deposits, great salt lake, utah, USA. Sediment. Geol. 2016, 341, 1-12. [CrossRef]

102. Vanden Berg, M. Domes, rings, ridges, and polygons: Characteristics of microbialites from utah's great salt lake. Sediment. Rec. 2019, 17, 4-10. [CrossRef]

103. Carozzi, A.V. Observations on algal biostromes in the great salt lake, utah. J. Geol. 1962, 70, $246-252$. [CrossRef]

104. Ginsburg, R.N.; Planavsky, N.J. Diversity of bahamian microbialite substrates. In Links Between Geological Processes, Microbial Activities\&Evolution of Life: Microbes and Geology; Dilek, Y., Furnes, H., Muehlenbachs, K., Eds.; Springer Netherlands: Dordrecht, The Netherlands, 2008; pp. 177-195, ISBN 978-1-4020-8306-8.

105. Quataert, E.; Storlazzi, C.; van Rooijen, A.; Cheriton, O.; van Dongeren, A. The influence of coral reefs and climate change on wave-driven flooding of tropical coastlines. Geophys. Res. Lett. 2015, 42, 6407-6415. [CrossRef]

106. Maloof, A.C.; Grotzinger, J.P. The Holocene shallowing-upward parasequence of north-west andros island, bahamas. Sedimentology 2012, 59, 1375-1407. [CrossRef]

107. Warren, J. Evaporites: Sediments, Resources and Hydrocarbons; Springer: Heidelberg, Germany, 2006.

108. Vennin, E.; Olivier, N.; Brayard, A.; Bour, I.; Thomazo, C.; Escarguel, G.; Fara, E.; Bylund, K.G.; Jenks, J.F.; Stephen, D.A.; et al. Microbial deposits in the aftermath of the end-Permian mass extinction: A diverging case from the Mineral Mountains (Utah, USA). Sedimentology 2015, 62, 753-792. [CrossRef]

109. Neuweiler, F. Development of albian microbialites and microbialite reefs at marginal platform areas of the Vasco-Cantabrian Basin (Soba reef area, Cantabria, N. Spain). Facies 1993, 29, 231-249. [CrossRef]

110. Visscher, P.T.; Stolz, J.F. Microbial Mats as Bioreactors: Populations, Processes, and Products; Elsevier: Amsterdam, The Netherlands, 2005; pp. 87-100.

111. Baumgartner, L.K.; Reid, R.P.; Dupraz, C.; Decho, A.W.; Buckley, D.H.; Spear, J.R.; Przekop, K.M.; Visscher, P.T. Sulfate reducing bacteria in microbial mats: Changing paradigms, new discoveries. Sediment. Geol. 2006, 185, 131-145. [CrossRef]

112. Visscher, P.T.; Reid, R.P.; Bebout, B.M. Microscale observations of sulfate reduction: Correlation of microbial activity with lithified micritic laminae in modern marine stromatolites. Geology 2000, 28, 919-922. [CrossRef]

113. Land, L.S. Failure to precipitate dolomite at $25^{\circ} \mathrm{C}$ Fromdilute solution despite 1000 -fold oversaturation after32 years. Aquat. Geochem. 1998, 4, 361-368. [CrossRef]

114. Warren, J. Dolomite: Occurrence, evolution and economically important associations. Earth Sci. Rev. 2000, 52, 1-81. [CrossRef]

115. Xu, J.; Yan, C.; Zhang, F.; Konishi, H.; Xu, H.; Teng, H.H. Testing the cation-hydration effect on the crystallization of Ca-Mg-CO3 systems. Proc. Natl. Acad. Sci. USA 2013, 110, 17750-17755. [CrossRef]

116. Vasconcelos, C.; Warthmann, R.; McKenzie, J.A.; Visscher, P.T.; Bittermann, A.G.; van Lith, Y. Lithifying microbial mats in lagoa vermelha, brazil: Modern precambrian relics? Sediment. Geol. 2006, 185, 175-183. [CrossRef] 
117. Van Lith, Y.; Warthmann, R.; Vasconcelos, C.; McKenzie, J.A. Microbial fossilization in carbonate sediments: A result of the bacterial surface involvement in dolomite precipitation. Sedimentology 2003, 50, $237-245$. [CrossRef]

118. Kenward, P.A.; Fowle, D.A.; Goldstein, R.H.; Ueshima, M.; González, L.A.; Roberts, J.A. Ordered low-temperature dolomite mediated by carboxyl-group density of microbial cell walls. AAPG Bull. 2013, 97, 2113-2125. [CrossRef]

119. Kenward, P.A.; Goldstein, R.H.; Gonzalez, L.A.; Roberts, J.A. Precipitation of low-temperature dolomite from an anaerobic microbial consortium: The role of methanogenic archaea. Geobiology 2009, 7, 556-565. [CrossRef]

120. Roberts, J.A.; Kenward, P.A.; Fowle, D.A.; Goldstein, R.H.; González, L.A.; Moore, D.S. Surface chemistry allows for abiotic precipitation of dolomite at low temperature. Proc. Natl. Acad. Sci. USA 2013, 110, 14540-14545. [CrossRef]

121. Konhauser, K. Introduction to Geomicrobiology; Blackwell Publishing: Malden, MA, USA, 2007.

122. Ferris, F.G.; Fyfe, W.S.; Beveridge, T.J. Metallic ion binding by Bacillus subtilis: Implications for the fossilization of microorganisms. Geology 1988, 16, 149-152. [CrossRef]

123. Grotzinger, J.; Al-Rawahi, Z. Depositional facies and platform architecture of microbialite-dominated carbonate reservoirs, ediacaran-Cambrian ara group, sultanate of oman. AAPG Bull. 2014, 98, 1453-1494. [CrossRef]

124. Mettraux, M.; Homewood, P.; Al Balushi, S.; Erthal, M.M.; Matsuda, N.S. Neoproterozoic microbialites in outcrops of the qarn Alam salt dome, central oman. GeoArabia 2014, 19, 17-79.

125. Perri, E.; Tucker, M.E.; Mawson, M. Biotic and abiotic processes in the formation and diagenesis of permian dolomitic stromatolites (Zechstein Group, NE England). J. Sediment. Res. 2013, 83, 896-914. [CrossRef]

(C) 2020 by the authors. Licensee MDPI, Basel, Switzerland. This article is an open access article distributed under the terms and conditions of the Creative Commons Attribution (CC BY) license (http://creativecommons.org/licenses/by/4.0/). 